\title{
Job-training programmes with low completion rates: the case of Projoven-Peru
}

\author{
Citation for published version (APA):
}

de Crombrugghe, D. P. I., Espinoza, H., \& Heijke, J. A. M. (2010). Job-training programmes with low completion rates: the case of Projoven-Peru. Researchcentrum voor Onderwijs en Arbeidsmarkt, Faculteit der Economische Wetenschappen. ROA Research Memoranda No. 4

https://doi.org/10.26481/umaror.2010004

Document status and date:

Published: 01/01/2010

DOI:

10.26481/umaror.2010004

Document Version:

Publisher's PDF, also known as Version of record

\section{Please check the document version of this publication:}

- A submitted manuscript is the version of the article upon submission and before peer-review. There can be important differences between the submitted version and the official published version of record.

People interested in the research are advised to contact the author for the final version of the publication, or visit the DOI to the publisher's website.

- The final author version and the galley proof are versions of the publication after peer review.

- The final published version features the final layout of the paper including the volume, issue and page numbers.

Link to publication

\footnotetext{
General rights rights.

- You may freely distribute the URL identifying the publication in the public portal. please follow below link for the End User Agreement:

www.umlib.nl/taverne-license

Take down policy

If you believe that this document breaches copyright please contact us at:

repository@maastrichtuniversity.nl

providing details and we will investigate your claim.
}

Copyright and moral rights for the publications made accessible in the public portal are retained by the authors and/or other copyright owners and it is a condition of accessing publications that users recognise and abide by the legal requirements associated with these

- Users may download and print one copy of any publication from the public portal for the purpose of private study or research.

- You may not further distribute the material or use it for any profit-making activity or commercial gain

If the publication is distributed under the terms of Article $25 \mathrm{fa}$ of the Dutch Copyright Act, indicated by the "Taverne" license above, 


\section{Job-training programmes with low completion rates: The case of Projoven-Peru}

Denis de Crombrugghe

Henry Espinoza

Hans Heijke

\section{ROA Research Memorandum}

ROA-RM-2010/4

Research Centre for Education and the Labour Market Maastricht University

P.O. Box 616,6200 MD Maastricht, The Netherlands

$\mathrm{T}+31433883647 \mathrm{~F}+31433884914$

secretary-roa-sbe@maastrichtuniversity.nl www.roa.nl 


\title{
Job-training programmes with low completion rates: The case of Projoven-Peru
}

\author{
Denis de Crombrugghe \\ Henry Espinoza \\ Hans Heijke
}

ROA-RM-2010/4*

April 2010

Research Centre for Education and the Labour Market

Maastricht University

P.O. Box 616, 6200 MD Maastricht, The Netherlands

$\mathrm{T}+31433883647 \mathrm{~F}+31433884914$

secretary-roa-sbe@maastrichtuniversity.nl

www.roa.nl

* The ROA Research Memorandum Series was created in order to make research results available for discussion, before those results are submitted for publication in journals. 


\begin{abstract}
Job-training programmes with low completion rates: The case of Projoven-Peru*

Projoven is an ongoing Peruvian youth job-training programme started in 1996 and conducted in successive waves or 'public calls'. The programme has two phases of instruction: i) three months of classroom training, followed by ii) three months of on-the-job training internship. From 1997 to 2007, less than 60\% of registrants completed both phases. This paper estimates the effectiveness of Projoven's sixth Public Call, in terms of overall and formal employment and wage outcomes, while accounting for the presence of trainees with partial instruction. Four groups are compared pairwise: the control group, the dropout group with only classroom training, the dropout group with classroom training and internship placement, and the group completing the full programme. Our estimations account for selection effects and the potential endogeneity of training completion. We find that in terms of overall and formal employment, the programme yields returns only in the short run and conditioned on internship completion. The programme seems to increase trainee wages, but these effects diminish over time. Projoven is relatively more effective for individuals with no work experience prior to enrolment.
\end{abstract}

JEL classification: $\mathrm{H} 43, \mathrm{I38}, \mathrm{O} 15$.

Keywords: youth job-training programme, Projoven, dropout, partial treatment, sample selection

Denis de Crombrugghe

Dept. of Quantitative Economics

Maastricht University

P.O. Box 616

6200 MD Maastricht

d.decrombrugghe@maastrichtuniversity.nl

Hans Heijke

Dept. of Economics and Research Centre for

Education and the Labour Market (ROA)

Maastricht University

P.O. Box 616

6200 MD Maastricht

h.heijke@maastrichtuniversity.nl

\section{Henry Espinoza}

Maastricht Graduate School of Governance

Maastricht University

P.O. Box 616

6200 MD Maastricht

henry.espinozapena@maastrichtuniversity.nl

** We are grateful to participants at the ROA Applied Economics Seminar (Maastricht), the LACEA Annual Meeting 2008 (Rio de Janeiro), and the 4th IZA/World Bank Conference on Employment and Development (Bonn), Annemarie Nelen and Raymond Montizaan for their valuable comments. Any remaining shortcomings are the responsibility of the authors. 


\section{Introduction}

During the 1980s, several stylized facts characterized the economies of Latin America: low rates of economic growth (lower than population growth), high external debt, constricted internal consumption and savings, high inflation, devaluation of local currencies, and expansion of the informal sector. As a consequence, during the late 1980s and early 1990s, many countries in the region implemented an accelerated process of structural reform, in accordance with the Washington Consensus. Some of the most dramatic reforms were carried out in labour markets, in order to increase their flexibility. ${ }^{1}$

In a post-structural-reform scenario, Latin American countries faced serious challenges to improving employment prospects for younger workers, particularly those from disadvantaged backgrounds. Beginning in the 1990s, by teaching participants labour skills and by providing work experience, youth jobtraining programmes (YJTP) attempted to mitigate the effects of structural reforms on economically disadvantaged youth. Such youth training programmes have been carried out throughout Latin America.

YJTPs have remained in operation in the region. They have endured as a response to the persistent income inequality and falling real earnings among young, low-skilled workers. According to the Economic Commission for Latin America (ECLAC, 2008), Latin American youth labour market participation rose from $59.4 \%$ to $62.8 \%$ between 1990 and 2006. During this period the average youth unemployment rate hovered around 13\%, and among low-income households, $24 \%$. Further, young workers were employed mostly in the informal sector, and social security coverage fell from $61 \%$ to $53 \%$. Youths represent $20 \%$ of the total population of Latin America as a whole. Since these workers are also bread-winners in their households, the effectiveness of YJTPs as policy intervention is critical.

In contrast with developed countries, where YJTPs yield modest, if any, effects on youth employment prospects (Heckman et al., 1999), training programmes are regarded as effective policy interventions in Latin America. Betcherman et al. (2004) and Ibarrarán and Rosas (2008) review numerous evaluation studies in the region and find that YJTPs generate positive and statistically significant effects on the employment prospects and earnings of the participants, particularly women. A distinctive feature that these authors point out is that most Latin American training programmes share a common two-step structure: i) classroom training, followed by ii) on-the-job training.

${ }^{1}$ See: Tokman and Martínez (1999); Egger and García (2000); IADB (2001); Saavedra (2003); and Chacaltana (2006). 
While training programmes are regarded as effective, they suffer from substantial dropout rates. In Peru, only $60 \%$ of participants complete the training; this rate ranges from $51 \%$ in Uruguay, to $74 \%$ in Chile, $77 \%$ in Panama, and $60 \%$ in the Dominican Republic. The dropout phenomenon has been neglected in most YJTP evaluation. Estimating treatment effects which account for trainees with partial instruction could yield a different perspective on YJTP effectiveness. Amalgamating completers and non-completers may confound differing effects. On the one hand, dropping out might imply not obtaining a certificate, which could cast the trainee negatively to potential employers. In such case, training participation cannot be regarded as beneficial. On the other hand, there are cases where dropping out is justified by the sudden emergence of appropriate job opportunities. Thus, there is the potential to erroneously attribute some outcomes to the programme. The theoretical relationship between non-completion of YJTPs and trainee labour market outcomes remains ambiguous and its relevance is therefore an empirical question. This paper aims to contribute to the evaluation literature by shedding light on the effectiveness of YJTPs in the presence of dropouts with partial treatment; we estimate the effects of Projoven-Peru (Projoven) on trainee labour market outcomes.

Projoven is an ongoing youth job-training programme initiated in 1996 and conducted at least once a year in successive waves or 'public calls'. Projoven is run by the Peruvian Ministry of Labour. The official goal of the programme is to facilitate the insertion of economically disadvantaged youth (16-24 years old) into the formal labour market by funding basic training in low-skilled occupations. The programme has two phases of instruction: i) three months of classroom training, followed by ii) three months of on-the-job training internship. Projoven finances training institutions (so-called ECAPs) to train participants at their own schools and to subsequently place them in on-the-job training internships.

This programme makes for an interesting case study. Projoven is a YJTP similar in design to others in Latin America and it has dropout rates similar to others in the region. A particular feature of Projoven, which distinguishes it from other youth programmes, is that trainees are paid (by the training firm) a minimum wage during the on-the-job-training internship. In our estimations, we use the Projoven sixth Public Call because availability of data from other Public Calls is limited. Existing studies evaluating Projoven's impact have been conducted and/or sponsored by the programme operator or by former employees of Projoven. The data set for the sixth Public call is the most complete one available. The Projoven sixth Public Call provides a unique data set that comprises measures of completion by trainees of the two phases of the programme as well as administrative records about the training providers. This data set comprises a 
baseline survey and three follow-up interviews: at six, twelve and eighteen months post-programme. ${ }^{2}$

We estimate the effectiveness of Projoven's sixth Public Call, in terms of overall and formal employment and wages, controlling for the presence of trainees with partial instruction. Four groups are compared pairwise: i) the control group with no treatment [G1], ii) the dropout group with only classroom training and no internship placement [G2], iii) the dropout group with classroom training and internship placement [G3], and iv) the treatment group with full treatment (classroom training and internship) [G4]. Our estimations account also for the potential endogeneity of completion, sample selection, and unobserved heterogeneity. As we observe evidence of a pre-training earnings dip, which could bias the treatment effect estimates (Heckman and Smith, 1999), we create a new control group that is a subsample of the individuals in the official control group. This new control group is built by using propensity score matching with replacement. The rationale is to create a more comparable control group to identify Projoven treatment effects. We check how sensitive our estimates are under the presence of unobservables, calculating the Rosenbaum (1995) bounds. Additionally, we allow the treatment effect to vary over time and with respect to particular individual characteristics (e.g., gender, working experience prior to training, and per-capita household income).

The effects of the Projoven sixth Public Call are assessed in three ways. First, to estimate the effects of Projoven sixth Public Call participation, we compare the labour market outcomes of [G2], [G3], and [G4] with [G1]. Secondly, for those groups that complete classroom training, we estimate the effects of Projoven sixth Public Call internship placement. These estimations are based on pairwise comparison of the labour market outcomes of [G3] and [G4] with [G2]. Thirdly, for the groups placed in internships, the effects of Projoven sixth Public Call internship completion are estimated. We compare the labour market outcomes of [G4] with [G3].

Overall employment likelihood is modelled using fixed-effects estimators. In the case of the effect of the programme on formal employment and wages, a sample selection correction is added as suggested by Wooldridge (1995). We also use an additional specification to allow for the presence of potential endogeneity of internship placement and completion; in this case, a two-stage least squares approach with sample selection correction (Semykina and Wooldridge, 2006) is applied.

\footnotetext{
${ }^{2}$ The periods post-programme refer to the calendar months after November 2000, when Projoven sixth Public Call training is expected to be completed at last.
} 
Our findings suggest that with respect to overall employment, Projoven yields limited returns. Programme effects diminish significantly over time and are conditioned on completion. Only individuals who complete the treatment [G4] experience positive and statistically significant returns, six months post-training, in comparison to non-participants [G1] and in comparison to dropouts [G3]. The effects of the programme are greater, and permanent, for those individuals with no work experience prior to training. Regarding formal employment, we find no evidence of statistically significant effects on trainees compared to nonparticipants. The effects of Projoven on formal employment are positive only when the training is completed [G4] and compared to dropouts [G3]. The effects on formal employment diminish over time but not significantly. These results hold even when training completion is considered to be endogenously determined.

With respect to monthly wages, the programme generates positive and significant returns for those trainees who at least achieved placement in an internship ([G3] and [G4]) in comparison to non-participants [G1]. Additionally, completing the two phases of instruction [G4] is rewarded more than dropping out [G3]. Compared to the non participants [G1], the effects of Projoven participation are persistent. They diminish over time but not significantly. In the case of internship completion, the effects are not persistent and diminish significantly over time. These results hold even when training completion is considered to be endogenously determined. In addition, the returns of the programme, in terms of monthly wages, are greater and persistent for individuals with no work experience and those in the lowest household income per-capita quartile.

The remainder of this paper proceeds as follows. Section 2 provides some background and the programme description. Section 3 presents a review of youth job-training programme evaluations, including Projoven. A description of the Projoven sixth Public Call data set and the way we address issues posed by the non-experimental design and the observed pre-treatment earnings dip is presented in Section 4. The empirical framework used to evaluate Projoven's effects is set out in Section 5. Section 6 presents the results of our estimations. Finally, Section 7 presents our conclusions.

\section{Background and Projoven-Peru description}

Projoven has trained more than 60,000 individuals in 15 Public Calls in 13 Peruvian cities from 1996 to 2007. A total of 3.6 million youth within the age bracket of 15-24 years (22\% of the Peruvian population) entered the workforce in this period. The programme attempted to mitigate the effects of the structural 
reforms on economically disadvantaged youngsters. The rationale was to improve the employment prospects of this demographic group to keep them out of drugs and criminal activities.

Despite the improvements in educational attainment, young cohorts traditionally exhibit higher unemployment rates than adults. During the period 1997-2007, the youth unemployment rate was stable at around 14\%, almost triple the corresponding rate for adults. The youth participation rate was stable at around $55 \%$, a $20 \%$ lower participation rate compared to adults. It is not surprising that youth have lower participation rates than adults since many are still in the process of acquiring basic human capital (through schooling). However, the proportion of youth neither working nor studying was on the increase in urban Peru during the period 1997-2007, whereas the proportion of youth engaged exclusively in study was slowly declining, from $32 \%$ to $29 \%$ over this period.

Young Peruvians may work, rather than staying in school, to help their households to deal with economic uncertainty. Unfortunately, youth work under precarious conditions; while the number of hours worked per week held at close to 41 hours, on average, during the period 1997-2007, the average real youth wage declined steeply (down $26 \%$ over the period). Additionally, 7 out of 10 worked in the informal labour market, with no social security coverage.

In this context, vocational training seems a suitable option for improving the employment prospects of economically disadvantaged youth. With the technical assistance of the International Labour Organization (ILO) and with a loan from the Inter-American Development Bank, Projoven began its operations in 1996 under the umbrella of the labour market policies of the Peruvian Ministry of Labour. Originally the programme was meant to be nationwide. However, budgetary constraints limited programme operations to a smaller target area.

Projoven's training courses are based on two main phases of instruction: classroom training and on-the-job-training internship. Preceding its training activities, the programme encompasses three preparatory phases: course selection, targeting, and (self) selection of participants and ECAP creaming. ECAP creaming refers to the process by which Projoven assigns trainees to courses and ECAPs decide upon assignments when vacancies are limited.

The course selection process begins when Projoven launches a call for training providers. Institutions interested in participating in the programme must register in the database of training providers called RECAP (Registro de Entidades de Capacitación). To be registered at RECAP, potential ECAPs must have a valid license from the Ministry of Education, possess proper facilities for teaching, and have a track record in vocational training. The ECAPs registered at RECAP are 
invited to present course proposals. The courses must be at a low skill level, terminal (training should be sufficient to get a job - not complementing other type of training/education), and most importantly labour-demand oriented (there should be firms requiring workers with the training). The courses should be designed for no more than 15-25 students per classroom, last between 200 and 300 hours with four to five contact hours per day spread over four or five days per week over 3 months. Proposals are selected based on a grading system. The most valued criteria for course selection is having the least unit cost per student and the commitment of the ECAP to place at least $60 \%$ of the trainees in internships.

Targeting and self-selection follows. Potential enrolees are targeted based on a poverty map. Projoven's branch offices in the selected cities conduct campaigns to recruit from the targeted population. The target group consists of youths between the ages of 16 and 24, in poverty status, and with low educational attainment. The programme operator usually places newspaper ads and distributes flyers in strategically selected locations, and invites potential participants and their parents to information meetings.

As programme participation is voluntary, participants self-select. Applicants who fulfil the requirements of age, poverty status, and low educational attainment are called back for a detailed evaluation of their eligibility. Potential trainees must fill in a socio-economic evaluation form (the FSEE), which collects information about educational attainment, job training experience, labour status, family composition, and living space. Based on this information, Projoven calculates a poverty score. Only participants above a certain poverty threshold are accredited. ${ }^{3}$

Finally, the ECAPs creaming process takes place. Accredited youths attend a meeting where they are informed about the available courses. The advantage of matching the courses closely with their skills is pointed out. Next, the potential participants take a vocational test and choose three course options. The test assesses the capacity of the applicant to execute simple arithmetic operations. The rationale for the test is to ascertain that potential trainees match the prerequisites of particular courses. For the most requested courses, Projoven sends up to three potential trainees for every vacancy available in each ECAP, based on trainee preferences and the results of the vocational test. Afterwards, the ECAP selects applicants based on interviews. No additional tests are allowed. Trainees not given their first option are reallocated according to their preferences in less sought-after courses.

\footnotetext{
${ }^{3}$ In order to be accredited, participants should have more than 11 points in their poverty score. The poverty score is based on a number of proxies for poverty status, but excludes income. Table A1 of the appendix explains the detailed composition of the poverty score index.
} 
Actual training begins after these preparatory phases. The three-month classroom training phase consists of training courses in standard settings in the form of classes and workshops. Projoven assumes tuition costs and pays the trainees stipends to cover transportation and food expenses. This amount can be marginally higher if the participant is a woman with children, in order to encourage her participation. Participants are also covered by basic health insurance financed by the programme operator during the instruction period.

The final phase of the programme is a three-month, on-the-job training internship. All participants who complete the classroom training, with attendance being the only requirement, are entitled in principle to start the onthe-job training phase. Almost all trainees complete the classroom training $(98 \%)$; however, the ECAPs fail to place around $20 \%$ of the trainees in internships. During the internship, the trainees should be under the supervision of a tutor. The assigned internship must consist of activities that complement the training received during classroom instruction. The programme operator supervises the development of this phase by interviewing the beneficiaries and participatingfirm managers. The ECAPs are responsible for the compatibility of course content with the internship.

\section{YJTP evaluation}

The objective of impact evaluation is to determine whether a social programme yields the expected outcomes on the treated population, and whether these outcomes are attributable to the programme (Heckman and Smith, 1997). Of particular interest is whether programme participants are better off than they would have been in the absence of the programme. There emerges the fundamental evaluation problem that no individual can be observed simultaneously in two mutually exclusive states, factual and counterfactual. One way to circumvent this problem is to create a control group to function as a substitute for the counterfactual. A control group can be created using either an experimental or a non-experimental design.

A purely experimental design is based on random assignment of the eligible population-in practice a sample thereof-into beneficiaries of the programme, the treatment group, and non-beneficiaries of the programme, the control group. Thus, the treatment effect is the average difference in the outcomes of the two groups, as treatment assignment is statistically independent of the outcomes. In a non-experimental design, the treatment is assigned in a non-random way. Individuals as similar as possible in observable covariates to the treated individuals are selected and function as control units. Often in practice, this 
control group is constructed only after the policy intervention; this is the design chosen by the Projoven programme operator for its own impact assessment.

The consistency of estimators based on non-experimental designs, in comparison with experimental ones, has been widely discussed. On the one hand, LaLonde (1986) points out that only experimental evaluations yield consistent average treatment effect (ATE) estimators, and demonstrates that estimators using a nonexperimental control group differ from those using experimental data. On the other hand, Heckman and Hotz (1989) and Dehejia and Wahba (1999) show how this LaLonde argument can break down if there are systematic differences between the treatment and control groups in observed as well as unobserved characteristics. Once Dehejia and Wahba (1999) control for systematic differences between non-experimental treatment and control groups (using LaLonde's approach to select the same controls), the ATE estimators are close to those obtained with experimental data.

One major concern is that differences between treatment and control groups in non-experimental designs remain unobserved or are due to self-selection into treatment. Individual decisions to comply with treatment could be related to its benefits. The literature on policy evaluation offers diverse methods to circumvent the limitations of non-experimental design. 4 Despite the development of sophisticated evaluation methods in a large number of studies, uncertainty persists about which kind of training works best, the appropriate doses of training, the individual characteristics most important for training effectiveness, and aggregate (general equilibrium) programme effects (Friedlander et al., 1997).

Friedlander et al. (1997) review prior evidence on the effects of YJTPs. These authors conclude that job-training programmes generally yield modest positive effects on employment and earnings for adult men and women, but fail to produce positive effects for youth. Heckman et al. (1999) compare YJTPs in the U.S. and in Europe; they find that in the U.S., YJTPs have no effect on earnings of economically disadvantaged youth and only a modest effect on employment rates. In Europe, results are similar with respect to earnings but more positive regarding employment levels. American studies use experimental designs more commonly than European studies. Political constraints and universal entitlement to social programmes make non-experimental designs the rule in Europe.

In the Latin American context, the evaluation of YJTPs leads to quite different conclusions compared with American and European programmes. YJTPs in

\footnotetext{
${ }^{4}$ For a review on methodologies used to evaluate policy interventions with non-experimental data see Heckman and Robb (1989); Friedlander and Robins (1995); Heckman and Smith (1997); and Heckman and Hotz (1989).
} 
Latin America are found to combine positive and statistically significant effects on earnings with small but significant effects on the probability of employment, particularly for women (Betcherman et al., 2004; Ibarrarán and Rosas, 2008). These results are not due to the fact that these studies are based on nonexperimental evaluations. Two studies that use experimental data for Dominican Republic (Card et al., 2007) and Colombia (Attanasio et al., 2008) also find positive returns for YJTP participants' employment likelihood and earnings.

An explanation for the higher impact of YJTPs on earnings in Latin America than in Europe and the U.S. may be found in the availability of alternative treatments. Should substitutes for the training programme be available (social assistance, counselling, etc.), then the experimental effect of the programme can be zero or negative, even if the effect of training relative to no training at all is large and positive (Heckman et al., 2000).

In most studies (Americans, Europeans or Latin Americans) the presence of trainees with only partial instruction has been neglected. Ignoring dropout could yield misleading conclusions about the effectiveness of training programs. For instance, if dropping out results from a job offer that is not attributable to the programme, we could erroneously ascribe to the programme a positive impact. If the dropouts have negative labour market outcomes, this may jeopardize the effectiveness of the whole programme.

\section{Projoven treatment effect evaluations}

Since its initiation, Projoven has used a non-experimental impact evaluation component. This evaluation component uses a selection of trainees and control groups in 6 out of 15 Public Calls of the programme. Yet, data availability remains a significant concern for independent evaluations. Studies evaluating Projoven's impact have been conducted or sponsored by the programme operator or by former employees of the institution. These studies have applied diverse evaluation methods, such as: before-and-after comparisons, differencesin-differences, cross-section-based estimators, and propensity score matching techniques. A summary of outcomes is given in Table 1. These studies report small improvements in employment prospects of up to $8 \%$, but these are mostly insignificant, along with more substantial income gains - in one case exceeding $100 \%$. The results, in terms of magnitude, are similar to those observed for other YJTPs in Latin America (Betcherman et al., 2004 and Ibarrarán and Rosas, 2007).

The differences observed among the estimates in the aforementioned studies illustrate and confirm the sensitivity of treatment-effect estimates to specification assumptions. Heckman and Smith (1997) explain that treatment effect estimators are highly dependent on model specifications. Some of these studies control for 
selection into treatment and pre-treatment earnings dip,, 5 and almost all consider different sources of heterogeneity of treatment, such as gender or hometown. However, none of these studies considers methods that allow for the presence of unobservables, such as instrumental variables or fixed-effects estimators. Only some, such as Burga (2003), Chong and Galdo (2006), and Diaz and Jaramillo (2006) use differences-in-differences estimators in a propensity-score matching context. None of the studies present any specification tests; they assume based on observables, that unobservables are balanced between the treated group and the control group.

The low completion rates of Projoven are also neglected in most of the studies. Failing to account for the low completion rate may bias the estimated effect of the programme. Heckman et al. (1998) and Heckman et al. (2000) pointed out that the unadjusted (by dropout) treatment effects estimates of the Job Training Partnership Act (JTPA) understate the effect of the training. Furthermore, empirical evidence suggests that job-training programmes are more effective once they are completed (Mealli et al., 1996); or yield higher returns the longer the trainees are exposed to training (Flores-Lagunes et al. 2007; Kluve et al., 2007). Regarding Projoven-Peru, only Chacaltana et al. (2003) and Chong and Galdo (2006) present estimations that, to some extent, do consider the impact of Projoven's low completion rate.

Using data from the sixth Public Call, Chacaltana et al. (2003) run cross-sectional OLS regressions of relative changes in hourly wages controlling for demographic variables, labour-related variables, and participation in Projoven. These regressions estimate Projoven's effects six, twelve, and eighteen months postprogramme. The low completion factor is taken into account via dummy variables that split Projoven's effect into two parts. The first dummy is activated for individuals who completed the first part of training but not the second. The second dummy is activated once the trainee has fully completed the training sequence. Chacaltana et al. (2003) find that the programme leads to increases in participants' monthly wages of about $18 \%$ to the extent that they completed the entire training sequence, but only in the short-run (six months post-programme). These investigators find no effects on trainee earnings after twelve months of either classroom training or on-the-job internship. We must note that Chacaltana et al. (2003) do not control for any pre-programme earnings dip, for selection into work, or for possible endogeneity of training completion.

Chong and Galdo (2006), using data from the first eight Public Calls of Projoven, apply a difference-in-differences approach with local linear propensity score

\footnotetext{
${ }^{5}$ Pre-treatment earnings dip refers to the decline in trainee earnings prior to training in comparison with the control group. In Section 4, a more detailed discussion addresses this topic.
} 
matching. They find positive and statistically significant returns in terms of monthly wages, which are larger for trainees who completed both phases of the programme in comparison with trainees who completed only the first phase. These authors take into account a pre-programme earnings dip in their matching process, but training completion is considered as if randomly assigned.

Evidence on Projoven evaluations suggests that the programme yields positive returns with respect to trainee employment likelihood and earnings. Nevertheless, the non-experimental design of these evaluations and the low completion phenomenon threaten the validity of these results. Questions remain about whether programme effects remain positive once corrections for sample selection and completion are considered.

\section{Data}

To evaluate Projoven effects on trainees' labour market outcomes, we use the Projoven sixth Public Call data set. This unique data set combines not only demographic information about trainees and the control group, but also administrative records on level of training completion. It allows us to match individual trainees with their specific training provider. Additionally, this was the only data set with the characteristics required for this study.

The Projoven sixth Public Call data set consists of a baseline survey, conducted in November 1999 (two to three months prior to programme commencement), and three follow-up comparison surveys: six months post-programme (May 2001), twelve months post-programme (November 2001), and eighteen months postprogramme (May 2002). Consequently, we observe individuals at four points in time. ${ }^{6}$

\section{Participation level}

The Projoven sixth Public Call data set includes 1,014 participants and an equal number of control group individuals. As reported in Figure 1, only $2.2 \%$ of sampled trainees did not complete classroom training. Some $41 \%$ of trainees completed the classroom training phase, but not the on-the-job training phase. The remaining $57 \%$ of trainees completed both phases of Projoven. Some $15.9 \%$ of trainees completed the classroom phase but were not placed in training firms by the ECAPs.

\footnotetext{
${ }^{6}$ Although the classroom training courses start at the same time, some delays occur before onthe-job training begins. Consequently, not all internships conclude at the same time. This affects the time at which follow-up surveys are carried out.
} 
Participants who spent only 1 or 2 months in Projoven are excluded from the estimation sample $(2.2 \%)$. It is unlikely that the programme yields measurable returns to trainees after such a short period and their number is too small to draw specific inferences. Thus, any participation in the programme implies completion of at least the classroom phase. We will, however, allow the training effect to vary by completion level.

\section{Control group formation}

To construct a control group, Projoven selects three comparable individuals per trainee, all required to be eligible and to satisfy enrolment requirements. The selection of control group individuals begins 2 months after training begins. The programme operator searches for potential controls in the same neighbourhoods as the actual trainees, or in the closest possible neighbourhoods within the same district. The rationale for this is that neighbourhood characteristics control for unobservable factors such as geographic segregation, transportation costs, firm location, etc., which may affect the likelihood of finding employment, and the potential outcomes of the training programme (Chong and Galdo, 2006). According to Friedlander and Robins (1995), the selection of control group individuals from the same geographic areas as the actual trainees produces treatment effect estimators that are close to the experimental ones. Projoven matches individuals in the control group with the trainees based on sex, age, labour status, poverty score, and education level. To be an adequate control for a participant trainee, an individual must:

- be of the same sex as the participant,

- be within a two-year age range around that of the participant,

- be within a five-point range with regard to the poverty score, 7 and

- have the same education level as the trainee.

All criteria must be satisfied simultaneously. Next, among the three controls selected per beneficiary, Projoven cleans and matches them one-to-one using a Mahalanobis metric approach. ${ }^{8}$

\footnotetext{
7 Table A1 of the Appendix explains the composition of the poverty score index.

8 Under this method, every trainee $i$ is matched with the control individual $j$ whose Mahalanobis distance is minimum. Mahalanobis distance: $\sqrt{\left(S_{i}-S_{j}\right)^{t} \Sigma^{-1}\left(S_{i}-S_{j}\right)}$, where $S_{i}$ is a vector containing the variables subject to matching for individual $i$, in this case sex, age, poverty score and education, and $\sum$ is an estimate of the variance-covariance matrix of the variables in $S_{i}$ and $S_{j}$.
} 
Non-experimental design and pre-programme earnings dip

Projoven's control matching is based on individual information at baseline (November 1999, 2 to 3 months prior to programme start). In the first two columns, [A] and [B], of Table 2, we observe that the original Projoven match in the sixth Public Call is perfectly executed at the level of cities of origin, education level, poverty score, labour status, and age. Nevertheless, there are notable differences in labour income and working hours, along with other variables. For instance, the difference in household income per capita suggests that the treated group is poorer than the control group. Another difference of concern is related to monthly wages prior to training. The average monthly wage for the control group is almost double the equivalent measure for the treated group. Such differences cast doubt on the comparability of the treatment and control groups for purposes of treatment effect evaluation.

This phenomenon of pre-programme earnings dip of the trainees is also notable in the fourth, eighth, and tenth Public Call surveys. This phenomenon is sometimes referred to as evidence of Ashenfelter's dip. ${ }^{9}$ Ashenfelter (1978) observed that trainee earnings tend to fall (absolutely and relatively), with respect to the control group, the year immediately prior to treatment. Heckman and Smith (1999) argue that this is a characteristic of virtually all training programmes and that it occurs despite the substantial variation in eligibility rules among training programmes. The occurrence of such pre-programme dip suggests that part of the observed increase in earnings that seems to follow a training programme may be explained as a return to a permanent path of earnings, temporarily interrupted by a transitory downward shock.

\section{Coping with non-experimental design and pre-programme earnings dip}

The pre-programme earnings dip represents evidence of systematic differences between the treatment and control groups prior to training, undermining their comparability. Ashenfelter (1978) suggests using an (even) earlier period as the baseline to circumvent possible biases caused by the pre-programme earnings dip. Unfortunately, in our case, there is no earlier period available. To deal with the pre-treatment wage difference in Projoven data, Nopo and Saavedra (2003); Ñopo et al. (2002); Projoven (2004), and Projoven (2005) suggest carrying out an additional individuals matching process. This additional matching procedure is adopted in this study to create a more comparable control group.

Matched sampling aims to produce a control group of modest size that is similar to the treated group in terms of the distribution of observed characteristics

\footnotetext{
9 See Ñopo and Saavedra (2003), Ñopo et al. (2002), Projoven (2004), and Projoven (2005).
} 
(Rosenbaum and Rubin, 1985). The drawback of this method is that there may be exact matches for only $50 \%$ of trainees (matching one-to-one without replacement). Discarding treated individuals is not an option, especially as the unmatched treated individuals may differ systematically from the matched treated individuals. ${ }^{10}$

We form a new control group using propensity-score matching with replacement. This allows us to keep all the treated individuals in the sample. It also implies that a control unit could be matched with one or more treated individuals. We match similar treated and non-treated individuals based on observables and labour force status transitions, as suggested by Heckman and Smith (1999). Based on Table 2 (columns [A] and [B]), we observe that apart from employment status transitions, work experience is an important predictor of Projoven participation. Additionally, being a non-wage family-business worker, not being married, not having children, and parents' higher education level, seem to encourage enrolment in training.

To ensure a better match on income level, we create 20 subsamples (by city, employment status, and level of income), for which matching based on propensity score is applied. However, the propensity score function is estimated using the complete sample. In Table A2 of the appendix, the distribution of the groups is shown to confirm the common support property. Table A3 of the appendix reports the probit regression for participation in Projoven given eligibility. Figure A1 displays the distribution of the estimated propensity scores.

Column [C] of Table 2 describes the new control group resulting from the one-toone matching with replacement based on the propensity score. In Table 2, 992 individuals are counted in the control group, but there are actually only 488 individuals-some are repeated. We observe that the differences in earnings between the treatment and control groups decline. Furthermore, we note that the groups are more similar with respect to household income per capita, having a child, being married and having an employment history prior to training. Henceforth, 'control group' refers to the newly created control group.

The new generated control group is similar in observables to the treated individuals. Propensity-score matching assumes that because the distribution of observables is similar, it is likely that the distribution of unobservables is also similar. However, the presence of unobservables, which affects both the outcome and selection into training, cannot be easily disregarded. Systematic differences not explained by the nature of the quasi-experiment constitute evidence that the non-experimental design failed to produce quasi-randomization. We test for

${ }^{10}$ Leuven and Oosterbeek (2006) discuss the problems inherent in small control groups. 
systematic differences prior to training between the newly created control group and the treated individuals.

We regress employment condition and monthly wages on individual characteristics and Projoven sixth Public Call participation prior to the programme. The rationale of the regression is to test whether there are systematic differences between the treatment and control groups prior to training. This is observable in the coefficient of the Projoven variable. Appendix Table A4 shows the results of these regressions. Whereas in the case of employment we find no systematic differences prior to training (Projoven coefficient not statistically different from zero), we observe differences between treatment and control groups in monthly wages (Projoven coefficient statistically different from zero). This suggests that if the labour market outcome to evaluate is employment, fixed-effects estimators would yield consistent results. However, if we evaluate monthly wages, the results may be affected by the presence of unobservables. Fortunately, it is possible to test how sensitive our estimates are given this circumstance.

The treatment effect literature (Rosenbaum, 1995; and Lee, 2005, Chapter 5) suggests several techniques to assess the impact of unobservables in treatment effect estimations. We use the Rosenbaum approach to measure how biases of various magnitudes might alter results. This approach does not indicate whether biases are present or what magnitude of bias is acceptable. Rather, it indicates how large the bias caused by unobservables (hidden bias) must be in order to alter our conclusions.

Rosenbaum's sensitivity analysis starts with the premise that hidden bias is present if two individuals $j$ and $k$ (one receiving treatment and the other not) with the same observed covariates $x\left(x_{j}=x_{k}\right)$ have different probability $\pi$ of receiving the treatment $\left(\pi_{j} \neq \pi_{k}\right)$. Now, let $j$ and $k$ be paired together. The odds that individuals $j$ and $k$ receive the treatment are, respectively, $\pi_{j} /\left(1-\pi_{j}\right)$ and $\pi_{k} /\left(1-\pi_{k}\right)$, and the odds ratio is the ratio of these odds. Following Rosenbaum (1995), if we know that this odds ratio for individuals with the same covariates is at most some number $\Gamma \geq 1$, then

[Eq. 1] $\frac{1}{\Gamma} \leq \frac{\pi_{j}\left(1-\pi_{k}\right)}{\pi_{k}\left(1-\pi_{j}\right)} \leq \Gamma$ for all $j, k$ with $x_{j}=x_{k}$.

If $\Gamma=1$, the results are free of hidden bias. If $\Gamma=2$, two individuals with similar covariates could differ in their odds of receiving the treatment, so one could be twice as likely as the other to receive the treatment. A sensitivity analysis would 
consider several possible values of $\Gamma$ and show how the inferences might change accordingly (Rosenbaum, 1995).

The results presented in Appendix Table A5 suggest that the effects of Projoven are not especially sensitive to the presence of hidden bias. Rosenbaum's analysis assumes matching without replacement. This could account for our finding. However, treatment effect estimation must address this issue. The availability of panel data for the Projoven sixth Public Call allows us to circumvent the possible distorted effect of time-constant unobservables in the estimation of Projoven treatment effects.

\section{Empirical framework}

Observational studies face not only the risk of potential hidden bias, but differing individuals levels of completion could bring about new sources of bias. We could underestimate the effects of the programme if these sources of bias materialize only on condition of completion. If the programme is not effective, we could attribute to the programme the wrong effect if the dropouts are better off. In this section, we develop a methodology to estimate Projoven treatment effect on trainees overall and specifically on formal employment and monthly wages. To mitigate the effects of different sources of bias in our analysis, four groups are compared pairwise: i) the control group with no treatment [G1], ii) the dropout group with only classroom training and no internship placement [G2], iii) the dropout group with classroom training and internship placement [G3], and iv) the treatment group with the full treatment (classroom training and internship) [G4]. Group composition is based on individual completion levels, as represented in Figure 2.

The distribution of individuals over different completion levels allow us to classify Projoven effects on trainee labour market outcomes (overall and formal employment, and monthly wages) in three categories: (A) the effect of participation in the programme, (B) the effect of internship placement, and (C) the effect of internship completion.

\section{The effect of participation in the programme}

To identify the effect of Projoven participation, we compare [G2] vs. [G1], [G3] vs. [G1], and [G4] vs. [G1]. A general specification of individual labour market outcomes is given by:

[Eq. 2] $Y_{i t}=X_{i t} \alpha+$ Projoven $_{\mathrm{it}} \beta_{1}+\eta_{i}+\delta_{t}+\varepsilon_{i t}$, 
where

$Y_{i t}=$ labour market outcome (overall or formal employment or wages) of individual $i$ in period $t$;

$X_{i t}=$ a row vector of measured individual characteristics affecting labour market outcomes;

Projoven $_{\mathrm{it}}=\mathrm{a}$ dummy variable measuring programme participation (1: only for trainees in the post-training periods; 0: otherwise);

$\eta_{i}=$ an error term specific to individual $i$ and constant over time;

$\delta_{t}=$ an error term specific to period $t$, and constant across individuals;

$\varepsilon_{i t}=$ an idiosyncratic error term specific to individual $i$ at period $t$; and

with $\alpha$ being a column vector of unknown parameters and $\beta_{1}$ being the unknown programme effect.

The presence of unobservables constant over time, $\eta_{i}$, can be circumvented by using fixed-effects estimators. These also allow for correlation between the unobservables and the explanatory variables, such as Projoven.

We use a threefold strategy for estimating the effects of Projoven participation. First, to estimate the effect on overall employment, we use a linear probability model (LPM) using fixed-effects estimators, as in:

[Eq. 3] $Y_{i t}=X_{i t} \alpha+$ Projoven $_{\mathrm{it}} \beta_{1}+\mathrm{D} 12 *$ Projoven $_{\mathrm{it}} \beta_{2}+\mathrm{D} 18 *$ Projoven $_{\mathrm{it}} \beta_{3}+\eta_{i}+\delta_{t}+\varepsilon_{i t}$,

where D12 and D18 are time dummies corresponding to the periods twelve and eighteen months after training, respectively. The interaction of these dummies and the Projoven variable allows the treatment to vary over time. Thus, the effect of Projoven sixth Public Call participation after six months, after twelve months and after eighteen months are represented by $\beta_{1} ; \beta_{1}+\beta_{2} ;$ and $\beta_{1}+\beta_{3}$, respectively.

Next, to estimate Projoven effects on formal employment, we use an LPM with fixed-effects estimator that corrects for sample selection (Wooldridge, 1995). These estimations follow a two-step approach. First, we use a standard Tobit regression of hours worked on observable covariates for each time period. Second, following Wooldridge (1995), the residuals of these estimations are included as additional regressors in [Eq. 3], which is estimated using fixed-effects estimators.

Finally, the Wooldridge (1995) procedure is used to estimate Projoven effects on monthly wages. 


\section{The effect of Projoven internship placement}

Internship placement is observed only in the case of trainees. Consequently, we rule out control group individuals from these estimations. To identify this effect, we compare [G3] vs. [G2], and [G4] vs. [G2]. To estimate the effects of internship placement on employment, we use an LPM fixed-effects estimator. In the case of effects on formal employment and monthly wages, we use the sample selection correction approach for fixed effects suggested by Wooldridge (1995). If we assume that trainees share similar observable and unobservable covariates, the methods suggested would yield consistent estimates of the programme effect.

We believe that internship placement is independent of trainee labour market outcomes, because internship placement does not depend on a trainee decision. Internship placement is a process that depends entirely on the ECAP's ability to network and place students. Additionally, Lee (2005, Chapter 5, Section 2) suggests that if the results are coherent with other auxiliary findings, we may claim that the assignment, in this case into internship, is not affected by unobservables. For instance, trainees who drop out of the internship should not have different outcomes than trainees who were not assigned into internships. We find that the coefficient of internship placement in the comparison of [G3] and [G2] is not statistically different from zero (See Panel B of Tables 3, 4 and 5). This lends support to our initial assumption of random assignment into internships. Additionally, the results of the Durbin-Wu-Hausman test in all the regressions indicate that the two-stage least squares specification is not the most efficient one. Nevertheless, we allow our estimates for potential endogeneity of internship completion.

To allow for potential endogeneity of internship placement, we use a pooled, two-stage least squares estimation, as suggested by Semykina and Wooldridge (2005). This method accounts for both possible endogeneity of training completion and sample selection. The sample selection correction is necessary in the formal employment and monthly wage models. The Semykina and Wooldridge approach follows a two-step procedure. First, it estimates probit regressions of employment condition in every period, adding Mundlak terms as regressors. ${ }^{11}$ From this, standard inverse Mills ratios are estimated. Second, it

\footnotetext{
${ }^{11}$ Mundlak terms consist of within-group means of several independent variables. In our case, these include: potential experience, household income per capita, being married, and having a child. With this strategy, unobserved heterogeneity is assumed to consist of two parts. The first part is uncorrelated with the observed variables. The second part is assumed to vary linearly with the group means, whereby a possible correlation between the independent variables and the unobserved heterogeneity is accounted for (Mundlak, 1978). The correlation between Mundlak terms and the exogenous variables does not affect our Projoven coefficients. We include in the Appendix [Table A25-Table A30] the results of the estimations using differently defined Mundlak terms (initial values instead of time averages), and without the use of Mundlak terms.
} 
models trainee labour market outcomes using pooled, two-stage least squares, adding as regressors the inverse Mills ratios and Mundlak terms for those individuals whose labour market outcomes are observed. The sample selection correction is excluded in the estimations of internship completion effects on overall employment.

We use as instruments for internship placement the type of ECAP - that is, CEO (centre for vocational training) and guilds (vocational centres sponsored by guilds). The rationale for the use of ECAP types as instruments is based on the fact that trainees do not know beforehand in which ECAP they will end up. Less than $20 \%$ of trainees are granted their first choice (Projoven, 2002). In addition, there is no way for trainees to know the returns on the training (of any ECAP) prior to training. To test this last statement, we include a regression of labour market outcomes on ECAP type. In Appendix Table A6 and Table A7, we observe that the type of ECAP has no impact on employment condition and monthly wages. As two types of ECAP are added as instruments, it is possible to perform the Sargan test of over-identification. In all cases, this test cannot reject the hypothesis that the instruments are suitable. The model is set up as follows:

[Eq. 4] $\quad \sum_{t=1}^{4} \delta_{t} \hat{\lambda}_{i t}+\bar{Z}_{i} \zeta+\delta_{t}+\varepsilon_{i t}$

$$
Y_{i t}=X_{i t} \alpha+\text { Internship }_{\mathrm{it}} \beta_{1}+\mathrm{D} 12 * \text { Internship }_{\mathrm{it}} \beta_{2}+\mathrm{D} 18 * \text { Internship }_{\mathrm{it}} \beta_{3}+
$$

where Internship is a dummy variable measuring internship placement (1: for trainees in the post-training periods placed in internships; 0: otherwise), $\bar{Z}_{i}$ represents a row vector containing the Mundlak terms, and $\hat{\lambda}_{i t}$ represents the estimated inverse Mills ratios. Thus, the effect of the Projoven internship after six months, after twelve months and after eighteen months is represented as $\beta_{1}$; $\beta_{1}+\beta_{2}$; and $\beta_{1}+\beta_{3}$, respectively.

\section{The effect of Projoven internship completion}

Internship completion is observed only for trainees who are placed in internships. Therefore, the evaluation sample in this case consists of trainees placed in internships ([G4] and [G3]). To evaluate the effects of internship completion on overall employment, we use the same techniques applied to evaluate the effects of internship placement. Additionally, we allow our estimate for endogeneity of internship completion. As in the previous case, ECAP type -

We observe that Projoven internship placement effect and Projoven internship completion effect vary very little with respect to the results with Mundlak terms. 
that is, CEO (centre for vocational training) and guilds (vocational centres sponsored by guilds) is used as an instrumental variable.

\section{Projoven heterogeneous treatment effects}

We test whether Projoven sixth Public Call participation or Projoven internship placement effect varies across particular individual characteristics; multiplicative dummies of Projoven participation (or, Projoven internship placement or Projoven internship completion) with these individual characteristics are added. Among such characteristics, we consider gender, work experience condition prior to training, and whether the trainee is in the lowest quartile of household income per capita prior to training.

[Eq. 5]

$$
\begin{aligned}
Y_{i t}= & X_{i t} \alpha+\text { Projoven }_{\mathrm{it}} *\left\{\left[\beta_{1}+\mathrm{D} 12 \beta_{2}+\mathrm{D} 18 \beta_{3}\right]+\right. \\
& \text { Fem }_{\mathrm{i}} *\left[\beta_{4}+\mathrm{D} 12 \beta_{5}+\mathrm{D} 18 \beta_{6}\right]+ \\
& \text { Noexp }_{\mathrm{i}} *\left[\beta_{7}+\mathrm{D} 12 \beta_{8}+\mathrm{D} 18 \beta_{9}\right]+ \\
& \text { Quart } \left._{\mathrm{i}} *\left[\beta_{10}+\mathrm{D} 12 \beta_{11}+\mathrm{D} 18 \beta_{12}\right]\right\}+ \\
& \eta_{i}+\delta_{t}+\varepsilon_{i t}
\end{aligned}
$$

where Fem is a dummy variable indicating whether an individual is female, Noexp indicates whether an individual has no experience prior to training, and Quart signals whether the individual is in the lowest quartile of household income per capita prior to training. Thus, the additional effects of the programme for women after six months, after twelve months and after eighteen months are represented by $\beta_{4} ; \beta_{4}+\beta_{5}$; and $\beta_{4}+\beta_{6}$, respectively. In the case of trainees with no work experience prior to training, the estimated additional effects of the programme after six months, after twelve months and after eighteen months are represented by $\beta_{7} ; \beta_{7}+\beta_{8}$; and $\beta_{7}+\beta_{9}$, respectively. Finally, in the case of trainees in the lowest household income per capita quartile prior to training, the estimated additional effects of the programme after six months, after twelve months and after eighteen months are represented by $\beta_{10} ; \beta_{10}+\beta_{11}$; and $\beta_{10}+\beta_{12}$, respectively.

In order to allow for the inclusion of variables that do not change over time, random effects estimators are used. For consistency, we condition these estimations on our previous fixed-effects results. We use as a dependent variable the residuals (with individual effects) of the estimations of Projoven effects on overall and formal employment and wages. As explanatory variables, Projoven 
interactions with time and with corresponding individual characteristics are considered.

\section{Results}

Tables 3, 4, and 5 display estimated Projoven sixth Public Call effects on overall employment, formal employment, and monthly wages, respectively. All three tables show the effects of the training over time and include three panels: A) Effects of Projoven participation, B) Effects of internship placement, and C) Effects of internship completion. These tables are complemented by Tables 6, 7 and 8, which present Projoven sixth Public Call effects on overall employment, formal employment, and monthly wages, respectively, allowing for endogeneity of internship placement and internship completion. Tables 9, 10, and 11 allow for the treatment to vary across particular individual characteristics. To allow heterogeneous treatment across individual characteristics, a more restrictive specification, random effects estimators, is used. Consequently, the estimates in Tables 9, 10, and 11 are presented as indicative of Projoven treatment effects across individual characteristics.

\section{Projoven effects on overall employment}

Table 3 sets forth the effects of the Projoven sixth Public Call on overall employment. ${ }^{12} \mathrm{We}$ observe that with respect to the no-programme situation, Projoven fails to yield permanent returns on employment at any level of completion (Panel A). However in the short run (six months post-training), the programme increases by $9 \%$ the likelihood of individual employment, but only for trainees who complete the internship (Panel A, [G4] vs. [G1] first column). This effect diminishes over time to the extent of becoming negative in the longrun (eighteen months post-training).

With respect to internship placement effects, we find no significant estimates over time (Panel B). The fact that the comparison of [G3] and [G2] generates no significant effects shows that internship placement could be regarded as if randomly assigned. The only difference between individuals in [G3] with respect to [G2] is that the [G2] individuals are not placed in internships. Since [G3] individuals did not complete the training, we would not expect a positive reward. These results also hold when allowing for internship placement to be endogenous as shown in Table 6. Table 6 shows that none of the coefficients reflecting the effect of internship placement are statistically significant. The same

\footnotetext{
12 Table 3 is a summary table. Complete regression results are reported in Appendix Tables A8, A9, and A10.
} 
phenomenon is observed in the estimations of formal employment and monthly wages.

In the case of internship completion, we observe that Projoven increases employment likelihood by $10 \%$ (Table 3, Panel C, [G4] vs. [G3], first column). The effects of internship completion hold in the medium-term (twelve months posttraining) and disappear in the long-run (eighteen months post-training) (Panel C, [G4] vs. [G3], second and third columns). The returns are similar when allowing the treatment to be endogenous (Table 6, Panel B, [G4] vs. [G3]). ${ }^{13}$ However, the returns are of a different magnitude $(24 \%)$ and do not vary significantly in the medium- or long-run.

Table 9 reports the effects of Projoven sixth Public Call while allowing for heterogeneous treatment across certain individual characteristics. ${ }^{14}$ We observe that the training yields no additional returns to women nor to individuals in the lowest household income per capita quartile prior to training (Panels A, B and C). However, Projoven increases the employment likelihood of individuals with no working experience prior to training at any the level of completion. These effects seem to be persistent and are greater in the long-run (eighteen months post-programme), conditioned on completion of training.

In summary, with respect to employment likelihood, Projoven yields limited returns. Only individuals who complete the treatment [G4] experience positive and significant returns compare to non-participants [G1] and compare to dropouts [G3]. The effects of the programme are greater for those individuals with no work experience prior to training, regardless of their level of completion.

Projoven effects on formal employment, controlling for sample selection

Table 4 sets forth the estimated effects of the Projoven sixth Public Call on formal employment, corrected for sample selection. ${ }^{15}$ The programme fails to yield any returns on trainees' formal employment condition when compared to nonparticipants [G1]. The coefficients estimated in Panel A are not significant.

Internship placement with respect to no internship placement increases the likelihood of employment in the formal labour market. However, these effects are not statistically significant (Panel B). Allowing internship placement to be

\footnotetext{
${ }^{13}$ Table 6 is a summary table. Complete regression results are reported in Appendix Tables A15, A16, and A17.

${ }^{14}$ Table 9 is a summary table. Complete regression results are reported in Appendix Tables A18, A19, and A24.

${ }^{15}$ Table 4 is a summary table. Complete regression results are reported in Appendix Tables A10, A11, and A12.
} 
endogenous shows similar results, but of different magnitude. Table 7 shows estimated effects larger than those in Table 4, but these are not significant. ${ }^{16}$

Comparison of [G4] and [G3] confirms that internship completion is rewarded more than dropping out. The returns obtained remain constant over time. No evidence of additional significant effects is found in the medium- and long-run (Table 4, Panel C, [G4] vs. [G3], second and third columns). The same results hold when allowing internship completion to be endogenous; however, the effects almost double in magnitude (Table 7, Panel C).

In the case of heterogeneous treatment, we find significant and positive effects only for those individuals with no work experience prior to training and for those in the lowest household income per capita quartile (Table 10). ${ }^{17}$ In the case of trainees with no work experience, these effects are conditioned on training completion compared to trainees not placed in internships (Table 10, Panel B, [G4] vs. [G2]). In the case of trainees in the lowest quartile, the effects are greater for the dropouts with internship placement [G3] compared to the nonparticipants [G1] (Table 10, Panel A, [G3] vs. [G1]).

In summary, the programme fails to yield returns with respect to formal employment. However, internship completion is rewarded more than dropping out in this respect. The effects of internship completion are persistent. As in the case of overall employment, Projoven produces additional returns to those individuals with no work experience and, in addition, to those in the lowest household income per capita quartile.

\section{Projoven effects on monthly wages, controlling for sample selection}

Table 5 sets forth estimated Projoven sixth Public Call effects on monthly wages corrected for sample selection. ${ }^{18}$ Panel A shows that compared to nonparticipants [G1], Projoven increases trainee wages by more than $30 \%$ for those who were at least placed in internships ([G3] and [G4]). These effects diminish significantly over time for programme completers [G4]. As discussed above, these results must be taken as indicative because we find systematic differences between trainees and the control group prior to training, in terms of wages.

\footnotetext{
${ }^{16}$ Table 7 is a summary table. Complete regression results are reported in Appendix Tables A15, A16, and A17.

17 Table 10 is a summary table. Complete regression results are reported in Appendix Tables A20, A22, and A24.

18 Table 5 is a summary table. Complete regression results are reported in Appendix Tables A10, A13, and A14.
} 
Panel B shows that internship placement yields no significant returns on monthly wages compared to the no-internship placement situation; the effects are even negative in the medium- and long-run (Panel B, [G4] vs. [G2], second and third columns). The results change only in terms of magnitude when allowing internship placement to be endogenous (Table 8). ${ }^{19}$ However, in the endogenous specification, effects are not significant.

Completing the Projoven internship relative to dropping out is definitively worthwhile, although the effects are not persistent and diminish over time. Controlling for internship completion endogeneity (Table 8, Panel B) does not change this assessment; only its magnitude differs.

In Table 11, we report estimates of Projoven sixth Public Call effects on monthly wages allowing for heterogeneous treatment across particular individual characteristics. ${ }^{20} \mathrm{We}$ observe that in comparison to non-participants and dropouts, Projoven yields additional returns for those trainees with no work experience prior to the training and for those in the lowest household income per capita quartile. For women, the programme is effective only in the long-run (eighteen months post-training), conditioned on completion ([G4]), compared to dropouts ([G2] and [G3]).

To summarize, with respect to monthly wages, Projoven can be regarded as an effective programme. The programme generates positive and significant returns for those trainees who at least were placed in an internship ([G3] and [G4]) in comparison to non-participation [G1]. Additionally, completing the training [G4] is rewarded more than dropping out [G3]. Finally, the effects of the programme are greater for those individuals with no work experience prior to training and for those in the lowest household income per capita quartile. For women, positive effects are observed only in the long-run conditioned on completion.

\section{Conclusions}

In Latin America, YJTPs are regarded as effective policy interventions. Studies have shown that these programmes raise trainee employment rates and wages, particularly for women (Betcherman et al., 2004 and Ibarrarán and Rosas, 2007). Nevertheless, these evaluations do not account for the low completion phenomenon. YJTPs in the region suffer from substantial dropout issues. On average, less than $70 \%$ of trainees complete the training. The analysis of Projoven

\footnotetext{
${ }^{19}$ Table 8 is a summary table. Complete regression results are reported in Appendix Tables A15, A16, and A17.

${ }^{20}$ Table 11 is a summary table. Complete regression results are reported in Appendix Tables A21, A23, and A24.
} 
sixth Public Call, a typical YJTP in the region, sheds light on the importance of controlling for low completion rates and the presence of unobservables in treatment effect estimations. This study addresses these issues. We reach four general conclusions:

First, the programme is not as effective as originally thought, in terms of employment, compared to non-participation [G1]. Only in the short run (six months post-training) and conditionally on internship completion [G4], do we observe a positive effect (of 9\%) on overall employment. This effect is not permanent and decreases over time. In addition, the programme produces no significant returns on formal employment; however, internship completion is more rewarded than dropping out in this respect.

Second, Projoven seems to be an effective policy intervention in terms of monthly wages. The programme increases monthly wages of trainees by more than $30 \%$ at all levels of completion. However, the effects on wages, which are in line with estimations from the literature, cannot be fully attributed to training. Although the construction of a new control group reduced significantly the differences in wages between the control group and trainees prior to the programme, some systematic differences are still observed. The fact that the programme yields no returns on formal employment excludes the possibility of explaining wage increases via productivity enhancement or trainees having better jobs. Actually, it seems that trainees work more hours in the same type of precarious jobs they would be working in the absence of the programme; our auxiliary Tobit regressions of hours worked proved this to be true.

Third, ignoring dropouts could lead to misleading conclusions about the effects of YJTPs. In the case of Projoven sixth Public Call, we observe that classroom training alone yields no returns on trainees overall, nor on formal employment or monthly wages. Nevertheless, once enrolled, the enrolee is definitively better off from completion of training. Under no circumstances are dropouts ([G2] and [G3]) better off with respect to employment prospects or wages. These results hold even when allowing for internship placement and completion to be endogenously determined.

Finally, our results suggest that the programme yields greater returns on overall and formal employment conditions for trainees with no work experience prior to training. In terms of monthly wages, the programme produces additional returns for individuals with no work experience and for those in the lowest household income per capita prior to training, but conditioned on completion [G4]. Contrary to previous findings, we do not find additional effects for women. We suspect the literature confounds the additional effects across individual characteristics with gender. Economically disadvantaged women are more likely 
to not have much work experience when they are young. However, these results must be taken as indicative, since our specification (random effects estimators) is more restricted.

To conclude, confounding the effects of unobservables and low completion rates yields a different picture of Projoven effects on trainee labour market outcomes. Decomposing programme effects by level of completion suggests that the programme is more effective, particularly with respect to wages and overall employment, conditioned on completion. Additionally, our results might imply a need to revise the targeting strategy and the official goals of the programme. In order to enhance training effects, the programme operator must encourage the participation of individuals with no work experience. In the low-skill job market, experience is regarded as more relevant than educational credentials. For youth with no work experience, attaining first-time employment is almost impossible in Peru. Thus, programmes that provide an internship (work experience) definitely impact their chances in the labour market. Given this, Projoven should consider strategies to make training more attractive and implement the right incentives for trainees to complete training. Further research is needed in order to determine why trainees drop out of the programme, particularly when completing the programme is demonstrably more rewarding. 


\section{References}

Attanasio, O., Kugler, A., Meghir, C., 2008. Training disadvantaged youth in Latin America: evidence from a randomized trial. NBER Working Paper 13931.

Angelucci, M., Attanasio, O., 2006. Estimating ATT effects with non-experimental data and low compliance. IZA Discussion Paper 2368.

Ashenfelter, O., 1978. Estimating the effect of training programs on earnings. Review of Economics and Statistics 60 (1), 47-57.

Betcherman, G., Olivas, K., Dar, A., 2004. Impacts of active labour market programs: new evidence from evaluations with particular attention to developing and transition countries. World Bank Social Protection Discussion Paper 0402.

Burga, C., 2003. Re-evaluando Projoven: propensity score matching y una evaluacion paramétrica. CIES, Lima.

Card, D., Ibarrarán, P., Regalia, F., Rosas, D., Soares, Y., 2007. The labour market impact of youth training in the Dominican Republic: evidence from a randomized evaluation. NBER Working Paper 12883.

Chacaltana, J., Guerrero, G., Espinoza, H. and Pain, O., 2003. ¿Qué funciona y qué no funciona en Projoven? Una evaluación de los procesos de capacitación y medición de impacto. IADB Report.

Chacaltana, J., Sulmont, D., 2004. Políticas activas en el mercado laboral peruano: el potencial de la capacitación y los servicios de empleo. In García, Chacaltana, Sulmont, Sierra, Sato y Jaramillo (2004), Políticas de empleo en el Perú. CIES, Lima.

Chong, A., Galdo, J., 2006. Does the quality of training programs matter? evidence from bidding processes data. IZA Discussion Paper 2202.

Dehejia, R., Wahba, S., 1999. Causal effects in non-experimental studies: reevaluating the evaluation of training programs. Journal of the American Statistical Association 94 (448), 1053-1062.

Díaz, J. J., Jaramillo, M., 2006. An evaluation of the Peruvian youth labor training program Projoven. Inter-American Development Bank Working Paper.

The Economic Commission for Latin America - ECLAC, 2008. Social panorama of Latin America. ECLAC, Santiago de Chile. 
Egger, P., García, N., 2000. Apertura económica y empleo: los países andinos de los noventa. OIT, Lima.

Flores-Lagunes, A., Gonzalez, A. and Neumann, T. C., 2007. Estimating the effects of length of exposure to a training program: the case of Job Corps. IZA Discussion Paper No. 2846.

Friedlander, D., Robins, P. K., 1995. Evaluating program evaluations: new evidence on commonly used non experimental methods. The American Economic Review 85 (4), 923-937.

Friedlander, D., Greenberg, D. H., Robins, P. K., 1997. Evaluating government training programs for the economically disadvantaged. Journal of Economic Literature 35 (4), 1809-1855.

Galdo, J., 1998. La evaluación de proyectos de inversión social: impacto del programa de capacitación laboral juvenil Projoven. Boletín de Economía Laboral 9, 11-30.

Heckman, J. J., Hotz, V. J., 1989. Choosing among non-experimental methods for estimating the impact of social programs: the case of manpower training. NBER Research Working Paper 2861.

Heckman, J., LaLonde, R., Smith, J., 1999. The economics and econometrics of active labor market programs. In Ashenfelter, O., Card, D., Handbook of Labor Economics, Vol. IV, 1865-2073.

Heckman, J. J., Hohmann, N., Smith, J., Khoo, M., 2000. Substitution and dropout bias in social experiments: a study of an influential social experiment. Quarterly Journal of Economics 115 (2), 651-694.

Heckman, J. J., Robb, R., 1989. Alternative methods for evaluating the impact of interventions: an overview. In Barnett, W. A., Gallant, A. R. (Eds.), New approaches to modelling, specification selection and econometric inference. Cambridge University Press, Cambridge.

Heckman, J. J., Smith, J. A., 1997. Experimental and non-experimental evaluation. In Schmid G., O'Reilly J., Schömann K. (Eds.), International handbook of labour market policy and evaluation. Edward Elgar Publishing Inc., Massachusetts. 
Heckman, J. J., Smith, J. A., 1999. The pre-program earnings dip and the determinants of participation in a social program: implications for simple program evaluation strategies. NBER Working Paper 6983.

Heckman, J. J., Smith, J. A., Taber, C., 1998. Accounting for dropouts in evaluation of social programs. The Review of Economics and Statistics 80 (1), 1-14.

Ibarrarán, P., Rosas, D., 2007. Impact evaluation of a labour training program in Panama. Inter-American Development Bank Working Paper.

Inter American Development Bank - IADB, 2001. Competitiveness: the business of growth. IADB, Washington.

LaLonde, R., 1986. Evaluating the econometric evaluations of training programs. American Economic Review 76 (4), 604-620.

Lee, M. J., 2005. Micro-econometrics for policy, program, and treatment effects. Oxford University Press, Oxford.

Leuven, E., Oosterbeek, H., 2006. An alternative approach to estimate the wage returns to private-sector training. Mimeo.

Mealli, F., Pudney, S., Thomas, J., 1996. Training duration and post-training outcome: a duration-limited competing risks model. The Economic Journal 106 (435), 422-433.

Mundlak, Y., 1978. On the pooling of time series and cross section data. Econometrica 46 (1), 69-85.

Ñopo, H., Robles, M., Saavedra, J., 2002. Una medición del impacto del programa de capacitación laboral juvenil Projoven. GRADE, Lima.

Ñopo, H., Saavedra, J., 2003. Evaluación de impacto de mediano plazo de Projoven. GRADE, Lima.

Projoven, 2000. Principales resultados de la evaluación de impacto: primera y segunda convocatoria. Ministerio de Trabajo y Promoción del Empleo, Lima.

Projoven, 2002. Informe sobre los procesos del área de focalización según sede regional: 9na Convocatoria. Ministerio de Trabajo y Promoción del Empleo, Lima.

Projoven, 2004. Evaluación de impacto de la octava convocatoria. Ministerio de Trabajo y Promoción del Empleo, Lima. 
Projoven, 2005. Primera evaluación de impacto décima convocatoria. Ministerio de Trabajo y Promoción del Empleo, Lima.

Rosenbaum, P. R., 1995. Observational studies. Springer-Verlag, New York.

Rosenbaum, P. R. and Rubin, D. B., 1985. Constructing a control group using multivariate matched sampling methods that incorporate the propensity score. The American Statistician 39 (1), 33-39.

Saavedra, J., 2003. Labor markets during the 1990's. In Kuczinski, P. P., Williamson J., After the Washington consensus: restarting growth and reform in Latin America. Institute for International Economics, Washington D.C.

Semykina, A., Wooldridge, J., 2006. Estimating panel data models in presence of endogeneity and selection: theory and application. Discussion paper, Department of Economics, Michigan State University, East Lansing, MI.

Tokman, V. E., Martínez, D. (Eds.), 1999. Inseguridad laboral y competitividad: modalidades de contratación. Oficina Internacional del Trabajo, Lima.

Wooldridge, J. M., 1995. Selection corrections for panel data models under conditional mean independence assumptions. Journal of Econometrics 68 (1), 115132. 
Table 1.

Estimated effects of Projoven on overall employment and wages.

\begin{tabular}{|c|c|c|c|c|c|c|c|c|}
\hline \multirow[t]{2}{*}{ Study } & \multirow{2}{*}{$\begin{array}{c}\text { Public } \\
\text { Call }\end{array}$} & \multicolumn{3}{|c|}{ Effect on employment } & \multicolumn{3}{|c|}{ Effect on monthly wages } & \multirow[t]{2}{*}{ Technique } \\
\hline & & $6 \mathrm{M}$ & $12 \mathrm{M}$ & $18 \mathrm{M}$ & $6 \mathrm{M}$ & $12 \mathrm{M}$ & $18 \mathrm{M}$ & \\
\hline Galdo (1998) & 1 & & & & $60 \% * * *$ & & & B\&A \\
\hline Burga $(2003)^{1}$ & 2 & $8.2 \% *$ & $25.9 \% * * *$ & $11.8 \% * * *$ & $28.7 \% *$ & $41.8 \% * * *$ & $28.6 \% *$ & PSMK \\
\hline \multirow{2}{*}{$\begin{array}{l}\text { Chacaltana and Sulmont } \\
(2004)\end{array}$} & 2 & & & & $44.8 \% *$ & $29.4 \%$ & $40.2 \% * *$ & OLS \\
\hline & 4 & & & & $38 \% * *$ & $54.5 \% * * *$ & $50.6 \% * * *$ & \\
\hline Ñopo et al. (2002) ${ }^{2}$ & 6 & $6.0 \% * * *$ & & & $18 \% * *$ & & & PSMNN \\
\hline $\begin{array}{l}\text { Ñopo and Saavedra } \\
(2003)^{3}\end{array}$ & 6 & $-1.7 \%$ & $-1.9 \%$ & $3.2 \%$ & $43.4 \%$ & $30.3 \%$ & $37.8 \%$ & PSMK \\
\hline Chacaltana et al. (2003) ${ }^{2}$ & 6 & & & & $12 \% *$ & n. r. & $13 \% *$ & OLS \\
\hline Projoven $(2004)^{3}$ & 8 & $2.7 \%$ & $2.6 \%$ & & $46.0 \%$ & $40.3 \%$ & & D-D \\
\hline Projoven $(2005)^{3}$ & 10 & $2.0 \%$ & & & $-3.0 \%$ & & & PSMK \\
\hline \multirow[t]{5}{*}{ Díaz and Jaramillo (2006) } & 1 & $-2.0 \%$ & $1.0 \%$ & $8.0 \%$ & $88.2 \% * * *$ & $88.0 \% * * *$ & $81.0 \% * * *$ & PSMK \\
\hline & 2 & $4.0 \%$ & $8.0 \%$ & $1.0 \%$ & $74.9 \% * * *$ & $111.8 \% * * *$ & $53.2 \% * *$ & \\
\hline & 4 & $3.0 \%$ & $4.0 \%$ & $3.0 \%$ & $44.5 \% * * *$ & $45.1 \% * * *$ & $64.0 \% * * *$ & \\
\hline & 6 & $3.0 \%$ & $-2.0 \%$ & $2.0 \%$ & $33.0 \% * * *$ & $33.0 \% * * *$ & $44.4 \% * * *$ & \\
\hline & 8 & $5.0 \%$ & $6.0 \%$ & & $57.3 \% * * *$ & $65.5 \% * * *$ & & \\
\hline \multirow[t]{5}{*}{ Chong and Galdo (2006) } & 1 & & & & $70 \% *$ & $24 \%$ & $58 \% *$ & LLME \\
\hline & 2 & & & & $52 \% *$ & $73 \% * *$ & $61 \% * *$ & \\
\hline & 4 & & & & $40 \% *$ & $11 \%$ & $34 \%$ & \\
\hline & 6 & & & & $33 \% *$ & $-5 \%$ & $20 \%$ & \\
\hline & 8 & & & & $67 \% * * *$ & $89 \% * * *$ & & \\
\hline
\end{tabular}

${ }^{*} p<0.10,{ }^{* *} p<0.05,{ }^{* * *} p<0.01$.

Notes:

6 M: 6 months after the programme; 12 M: 12 months after the programme; 18 M: 18 months after the programme

n. r.: Not reported.

B\&A: Before-and-after comparison.

D-D: Diff-in-Diff (simple version).

PSMK: Diff-in-Diff with propensity score matching kernel estimator.

PSMNN: Diff-in-Diff with propensity score matching nearest neighbour.

LLME: Diff-in-Diff with local linear matching estimator.

${ }^{1}$ The effect on employment refers to the effect on hours worked.

2 The effect on wages refers to the effect on hourly wages.

${ }^{3}$ These studies do not report standard errors. 
Table 2.

Baseline summary statistics [2-3 months before training]. Projoven sixth Public Call.

\begin{tabular}{|c|c|c|c|c|c|c|c|c|}
\hline & \multicolumn{2}{|c|}{$\begin{array}{l}\text { Official control } \\
\text { group }[\mathrm{A}]\end{array}$} & \multicolumn{2}{|c|}{ Treated group [B] } & \multicolumn{2}{|c|}{$\begin{array}{l}\text { New control } \\
\text { group }[C]\end{array}$} & \multicolumn{2}{|c|}{$\begin{array}{c}p \text {-value [mean } \\
\text { differences] }\end{array}$} \\
\hline & Mean & $\begin{array}{l}\text { Std. } \\
\text { dev. }\end{array}$ & Mean & $\begin{array}{l}\text { Std. } \\
\text { dev. }\end{array}$ & Mean & $\begin{array}{l}\text { Std. } \\
\text { dev. }\end{array}$ & $\begin{array}{c}\text { [A] vs. } \\
{[\mathrm{B}]}\end{array}$ & $\begin{array}{c}\text { [B] vs. } \\
{[\mathrm{C}]}\end{array}$ \\
\hline Total & \multicolumn{2}{|c|}{1,014} & \multicolumn{2}{|c|}{992} & \multicolumn{2}{|c|}{992} & & \\
\hline \multicolumn{9}{|l|}{ City } \\
\hline Arequipa & 0.20 & $(0.40)$ & 0.21 & $(0.41)$ & 0.21 & $(0.41)$ & 0.804 & 1.000 \\
\hline Chiclayo & 0.12 & $(0.33)$ & 0.11 & $(0.31)$ & 0.11 & $(0.31)$ & 0.509 & 1.000 \\
\hline Cusco & 0.12 & $(0.32)$ & 0.12 & $(0.32)$ & 0.12 & $(0.32)$ & 0.858 & 1.000 \\
\hline Lima & 0.36 & $(0.48)$ & 0.36 & $(0.48)$ & 0.36 & $(0.48)$ & 0.963 & 1.000 \\
\hline Trujillo & 0.20 & $(0.40)$ & 0.20 & $(0.40)$ & 0.20 & $(0.40)$ & 0.938 & 1.000 \\
\hline Age (years) & 19.76 & $(2.35)$ & 19.60 & $(2.44)$ & 19.72 & $(2.41)$ & 0.133 & 0.301 \\
\hline Female & 0.51 & $(0.50)$ & 0.52 & $(0.50)$ & 0.55 & $(0.50)$ & 0.790 & 0.163 \\
\hline Poverty score & 18.95 & $(2.95)$ & 16.71 & $(4.13)$ & 18.78 & $(2.97)$ & 0.000 & 0.000 \\
\hline Household income per capita (S/.) & 150.27 & $(85.28)$ & 127.40 & $(91.31)$ & 129.79 & $(77.95)$ & 0.000 & 0.476 \\
\hline Child & 0.24 & $(0.43)$ & 0.14 & $(0.35)$ & 0.15 & $(0.36)$ & 0.000 & 0.487 \\
\hline Married & 0.22 & $(0.41)$ & 0.10 & $(0.30)$ & 0.12 & $(0.32)$ & 0.000 & 0.253 \\
\hline Years schooling & 10.45 & $(1.30)$ & 10.45 & $(1.34)$ & 10.42 & $(1.34)$ & 1.000 & 0.558 \\
\hline Father tertiary education & 0.08 & $(0.27)$ & 0.12 & $(0.33)$ & 0.10 & $(0.30)$ & 0.001 & 0.085 \\
\hline Mother tertiary education & 0.03 & $(0.17)$ & 0.06 & $(0.25)$ & 0.04 & $(0.18)$ & 0.000 & 0.005 \\
\hline \multicolumn{9}{|l|}{ Labour market status } \\
\hline Employed & 0.60 & $(0.49)$ & 0.60 & $(0.49)$ & 0.60 & $(0.49)$ & 0.964 & 1.000 \\
\hline Unemployed & 0.29 & $(0.46)$ & 0.27 & $(0.44)$ & 0.26 & $(0.44)$ & 0.183 & 0.839 \\
\hline \multicolumn{9}{|l|}{$\begin{array}{l}\text { Transitions (\%) (from October } 1999 \\
\text { to November 1999) }\end{array}$} \\
\hline Unemployed/OLF -> employed & 0.08 & $(0.27)$ & 0.08 & $(0.28)$ & 0.10 & $(0.29)$ & 0.872 & 0.269 \\
\hline $\begin{array}{l}\text { Employed -> Unemployed/OLF } \\
\text { Unemployed/OLF -> }\end{array}$ & 0.04 & $(0.20)$ & 0.04 & $(0.20)$ & 0.03 & $(0.17)$ & 0.911 & 0.230 \\
\hline Unemployed/OLF & 0.41 & $(0.49)$ & 0.46 & $(0.50)$ & 0.42 & $(0.49)$ & 0.025 & 0.161 \\
\hline Employed -> employed & 0.47 & $(0.50)$ & 0.42 & $(0.49)$ & 0.45 & $(0.50)$ & 0.018 & 0.222 \\
\hline No work experience & 0.28 & $(0.45)$ & 0.37 & $(0.48)$ & 0.35 & $(0.48)$ & 0.000 & 0.242 \\
\hline Non-wage family-business worker & 0.07 & $(0.25)$ & 0.13 & $(0.34)$ & 0.17 & $(0.37)$ & 0.000 & 0.039 \\
\hline \multicolumn{9}{|l|}{ Labour income $^{1}(S / .2001)$} \\
\hline Monthly 1 & 238.71 & $(148.21)$ & 158.93 & $(134.78)$ & 173.65 & $(135.14)$ & 0.000 & 0.053 \\
\hline Hourly & 1.49 & $(1.05)$ & 1.12 & $(0.92)$ & 1.23 & $(1.07)$ & 0.000 & 0.049 \\
\hline Working hours1 (week) & 55.21 & $(139.06)$ & 46.76 & (114.75) & 42.30 & $(83.67)$ & 0.249 & 0.444 \\
\hline
\end{tabular}

1 Only considering individuals working in the reference period.

2 Ho: Means differences $=0$.

Source: Projoven. 
Table 3.

Linear probability model - fixed effect estimations. Projoven sixth Public Call effects on overall employment by level of completion.

\begin{tabular}{ccc}
$\begin{array}{c}\text { Effects } \\
\text { after 6 } \\
\text { months }\end{array}$ & $\begin{array}{c}\text { Additional } \\
\text { effects after } \\
\mathbf{1 2} \text { months }\end{array}$ & $\begin{array}{c}\text { Additional } \\
\text { effects after } \\
\mathbf{1 8} \text { months }\end{array}$ \\
{$\left[\hat{\beta}_{1}\right]$} & {$\left[\hat{\beta}_{2}\right]$} & {$\left[\hat{\beta}_{3}\right]$} \\
\hline
\end{tabular}

\begin{tabular}{|c|c|c|c|}
\hline \multicolumn{4}{|c|}{ A. Effects of Projoven participation } \\
\hline \multirow[t]{2}{*}{ [G2] vs. [G1] } & 0.033 & -0.036 & -0.069 \\
\hline & $(0.059)$ & $(0.051)$ & $(0.056)$ \\
\hline \multirow[t]{2}{*}{ [G3] vs. [G1] } & -0.006 & -0.068 & -0.018 \\
\hline & $(0.054)$ & $(0.045)$ & $(0.054)$ \\
\hline \multirow[t]{2}{*}{ [G4] vs. [G1] } & $0.091^{* *}$ & $-0.105^{* * *}$ & $-0.125^{* * *}$ \\
\hline & $(0.044)$ & $(0.036)$ & $(0.043)$ \\
\hline \multicolumn{4}{|c|}{ B. Effects of Projoven internship placement } \\
\hline \multirow[t]{2}{*}{ [G3] vs. [G2] } & -0.041 & -0.033 & 0.051 \\
\hline & $(0.062)$ & $(0.056)$ & $(0.057)$ \\
\hline \multirow[t]{2}{*}{ [G4] vs. [G2] } & 0.055 & -0.063 & -0.049 \\
\hline & $(0.054)$ & $(0.048)$ & $(0.048)$ \\
\hline \multicolumn{4}{|c|}{ C. Effects of Projoven internship completion } \\
\hline \multirow[t]{2}{*}{ [G4] vs. [G3] } & $0.103^{*}$ & $-0,014$ & $-0.109^{*}$ \\
\hline & $(0.061)$ & $(0.051)$ & $(0.059)$ \\
\hline
\end{tabular}

${ }^{*} p<0.10,{ }^{* *} p<0.05, * * * p<0.01$.

[G1]: Control group (992 individuals).

[G2]: Dropout group with only classroom training and no internship placement (183 individuals).

[G3]: Dropout group with classroom training and internship placement (231 individuals).

[G4]: Treatment group with the full treatment (578 individuals).

Clustered robust standard errors in parentheses.

[ $\hat{\beta}_{1}$ ] represents the treatment effect 6 months after the training; with $\left[\hat{\beta}_{2}\right],\left[\hat{\beta}_{3}\right]$ additional effects in the following periods.

The time dimension of the panel consists of four time periods: Nov-99, May-01, Nov-01, and May-02. This represents baseline before Projoven, 6 months after Projoven, 12 months after Projoven, and 18 months after Projoven, respectively. In all models, the base periods are Nov-99 and May-01. Two base periods are chosen, as the treatment variable takes the value zero for all individuals (treatment and controls) before the programme (Nov-99).

Table 3 is a summary table. Completed regression results are reported in Appendix Tables A8, A9 and A10. 
Table 4.

Linear probability model fixed-effects estimates with sample selection correction (Wooldridge, 1995). Projoven sixth Public Call effects on formal employment by level of completion.

\begin{tabular}{ccc}
$\begin{array}{c}\text { Effects after } \\
6 \text { months } \\
\left.\hat{\beta}_{1}\right]\end{array}$ & $\begin{array}{c}\text { Additional effects } \\
\text { after 12 months }\end{array}$ & $\begin{array}{c}\text { Additional effects } \\
\text { after 18 months }\end{array}$ \\
{$\left[\hat{\beta}_{2}\right]$} & {$\left[\hat{\beta}_{3}\right]$} \\
\hline
\end{tabular}

\section{A. Effects of Projoven participation}

$\begin{array}{lccc}\text { [G2] vs. [G1] } & -0.046 & -0.020 & -0.123^{*} \\ & (0.085) & (0.070) & (0.069) \\ \text { [G3] vs. [G1] } & 0.012 & -0.011 & -0.078 \\ & (0.075) & (0.055) & (0.058) \\ \text { [G4] vs. [G1] } & 0.081 & -0.010 & -0.071 \\ & (0.065) & (0.047) & (0.049)\end{array}$

B. Effects of Projoven internship placement

$\begin{array}{lccc}\text { [G3] vs. [G2] } & 0.032 & 0.031 & 0.036 \\ & (0.094) & (0.077) & (0.074) \\ \text { [G4] vs. [G2] } & 0.092 & 0.048 & 0.067 \\ & (0.076) & (0.067) & (0.063)\end{array}$

C. Effects of Projoven internship completion

$\begin{array}{llll}\text { [G4] vs. [G3] } & 0.187^{*} & -0.014 & -0.029 \\ & (0.097) & (0.077) & (0.071)\end{array}$

${ }^{*} p<0.10,{ }^{* *} p<0.05, * * * * 0.01$.

[G1]: Control group (992 individuals).

[G2]: Dropout group with only classroom training and no internship placement (183 individuals).

[G3]: Dropout group with classroom training and internship placement (231 individuals).

[G4]: Treatment group with the full treatment (578 individuals).

Clustered robust standard errors are in parentheses.

[ $\hat{\beta}_{1}$ ] represents the treatment effect 6 months after the training; with $\left[\hat{\beta}_{2}\right],\left[\hat{\beta}_{3}\right]$ additional effects in the following periods.

The time dimension of the panel consists of four time periods: Nov-99, May-01, Nov-01, and May-02. This represents baseline before Projoven, 6 months after Projoven, 12 months after Projoven and 18 months after Projoven, respectively. In all models, the base periods are Nov-99 and May-01. Two base periods are chosen, as the treatment variable takes the value zero for all individuals (treatment and controls) before the programme (Nov-99).

Table 4 is a summary table. Completed regression results are reported in Appendix Tables A10, A11, and A12. 
Table 5.

Fixed-effects estimates with sample selection correction (Wooldridge, 1995). Projoven sixth Public Call effects on monthly wages by level of completion.

\begin{tabular}{ccc}
$\begin{array}{c}\text { Effects } \\
\text { after 6 } \\
\text { months }\end{array}$ & $\begin{array}{c}\text { Additional } \\
\text { effects after 12 } \\
\text { months }\end{array}$ & $\begin{array}{c}\text { Additional } \\
\text { effects after 18 } \\
\text { months }\end{array}$ \\
{$\left[\hat{\beta}_{1}\right]$} & {$\left[\hat{\beta}_{2}\right]$} & {$\left[\hat{\beta}_{3}\right]$} \\
\hline
\end{tabular}

$\begin{array}{cccc}\text { A. Effects of Projoven participation } & & \\ \text { [G2] vs. [G1] } & 0.332 & -0.025 & 0.105 \\ & (0.135) & (0.096) & (0.098) \\ \text { [G3] vs. [G1] } & 0.341^{* * *} & 0.106 & 0.126 \\ & (0.124) & (0.084) & (0.095) \\ \text { [G4] vs. [G1] } & 0.382^{* * *} & -0.140^{* *} & -0.089 \\ & (0.095) & (0.063) & (0.066)\end{array}$

B. Effects of Projoven internship placement

$\begin{array}{cccc}\text { [G3] vs. [G2] } & 0.087 & 0.073 & -0.017 \\ & (0.143) & (0.109) & (0.109) \\ \text { [G4] vs. [G2] } & 0.109 & -0.163^{*} & -0.268^{* * *} \\ & (0.124) & (0.088) & (0.090)\end{array}$

C. Effects of Projoven internship completion

\begin{tabular}{cccc} 
[G4] vs. [G3] & $0.351^{* *}$ & $-0.263^{* *}$ & $-0.354^{* * *}$ \\
& $(0.139)$ & $(0.110)$ & $(0.112)$ \\
\hline$* p<0.10,{ }^{* *} p<0.05,{ }^{* * *} p<0.01$.
\end{tabular}

[G1]: Control group (992 individuals).

[G2]: Dropout group with only classroom training and no internship placement (183 individuals).

[G3]: Dropout group with classroom training and internship placement (231 individuals)

[G4]: Treatment group with the full treatment (578 individuals).

Clustered robust standard errors are in parentheses.

[ $\hat{\beta}_{1}$ ] represents the treatment effect 6 months after the training; with $\left[\hat{\beta}_{2}\right],\left[\hat{\beta}_{3}\right]$ additional effects in the following periods.

The time dimension of the panel consists of four time periods: Nov-99, May-01, Nov-01, and May-02. This represents baseline before Projoven, 6 months after Projoven, 12 months after Projoven, and 18 months after Projoven, respectively. In all models, the base periods are Nov-99 and May-01. Two base periods are chosen, as the treatment variable takes the value zero for all individuals (treatment and controls) before the programme (Nov-99).

Table 5 is a summary table. Completed regression results are reported in Appendix Tables A10, A13, and A14. 
Table 6.

Pooled linear probability model - two-stage least squares estimates. Projoven sixth Public Call effects on overall employment by level of completion. Heterogeneous treatment over time and endogenous treatment.

\begin{tabular}{cccc}
$\begin{array}{c}\text { Effects } \\
\text { after 6 } \\
\text { months }\end{array}$ & $\begin{array}{c}\text { Additional } \\
\text { effects after 12 } \\
\text { months }\end{array}$ & $\begin{array}{c}\text { Additional } \\
\text { effects after } \\
18 \text { months }\end{array}$ & $\begin{array}{c}\text { Durbin-Wu- } \\
\text { Hausman test }\end{array}$ \\
{$\left[\hat{\beta}_{1}\right]$} & {$\left[\hat{\beta}_{2}\right]$} & {$\left[\hat{\beta}_{3}\right]$} & \\
\hline
\end{tabular}

A. Effects of Projoven internship placement

$\begin{array}{lcccc}\text { [G3] vs. [G2] } & 0.134 & 0.196 & 0.075 & \chi_{(3)}^{2}=3.27009 \\ & (0.401) & (0.423) & (0.408) & P \text {-val }=0.2709 \\ \text { [G4] vs. [G2] } & 0.255 & -0.115 & -0.137 & \chi_{(3)}^{2}=2.44577 \\ & (0.184) & (0.201) & (0.195) & P \text {-val }=0.48517\end{array}$

B. Effects of Projoven internship completion

\begin{tabular}{ccccc} 
[G4] vs. [G3] & $0.245^{*}$ & -0.131 & 0.010 & $\chi_{(3)}^{2}=3.16819$ \\
& $(0.130)$ & $(0.143)$ & $(0.134)$ & $P$-val $=0.36641$ \\
\hline
\end{tabular}

${ }^{*} p<0.10,{ }^{* *} p<0.05, * * * x<0.01$.

[G1]: Control group (992 individuals).

[G2]: Dropout group with only classroom training and no internship placement (183 individuals).

[G3]: Dropout group with classroom training and internship placement (231 individuals).

[G4]: Treatment group with the full treatment (578 individuals).

Clustered robust standard errors are in parentheses.

[ $\hat{\beta}_{1}$ ] represents the treatment effect 6 months after the training; with $\left[\hat{\beta}_{2}\right],\left[\hat{\beta}_{3}\right]$ additional effects in the following periods.

The time dimension of the panel consists of four time periods: Nov-99, May-01, Nov-01, and May-02. This represents baseline before Projoven, 6 months after Projoven, 12 months after Projoven, and 18 months after Projoven, respectively. In all the models, the base periods are Nov99 and May-01. Two base periods are chosen, as the treatment variable takes the value zero for all individuals (treatment and controls) before the programme (Nov-99).

Table 6 is a summary table. Completed regression results are reported in Appendix Tables A15, A16 and A17. 
Table 7.

Pooled linear probability model - two-stage least squares estimates with sample selection correction (Semykina and Wooldridge, 2006). Projoven sixth Public Call effects on formal employment by level of completion. Heterogeneous treatment over time and endogenous treatment.

\begin{tabular}{cccc}
\hline $\begin{array}{c}\text { Effects } \\
\text { after 6 } \\
\text { months } \\
{\left[\hat{\beta}_{1}\right]}\end{array}$ & $\begin{array}{c}\text { Additional } \\
\text { effects after 12 } \\
\text { months }\end{array}$ & $\begin{array}{c}\text { Additional } \\
\text { effects after } \\
18 \text { months }\end{array}$ & $\begin{array}{c}\text { Durbin-Wu- } \\
\text { Hausman test }\end{array}$ \\
\hline$\left.\hat{\beta}_{2}\right]$ & {$\left[\hat{\beta}_{3}\right]$} & \\
\hline
\end{tabular}

A. Effects of Projoven internship placement

$\begin{array}{ccccc}\text { [G3] vs. [G2] } & 0.632 & -0.104 & -0.264 & \chi_{(3)}^{2}=6.10664 \\ & (0.510) & (0.558) & (0.510) & P \text {-val }=0.10654 \\ \text { [G4] vs. [G2] } & 0.747 & 0.039 & -0.388 & \chi_{(3)}^{2}=4.26172 \\ & (0.781) & (0.752) & (0.745) & P \text {-val }=0.23455\end{array}$

B. Effects of Projoven internship completion

\begin{tabular}{ccccc} 
[G4] vs. [G3] & $0.442^{* * *}$ & -0.009 & -0.292 & $\chi_{(3)}^{2}=3.73153$ \\
& $(0.166)$ & $(0.152)$ & $(0.255)$ & $P$-val $=0.29195$ \\
\hline
\end{tabular}

${ }^{*} p<0.10,{ }^{* *} p<0.05,{ }^{* * *} p<0.01$.

[G1]: Control group (992 individuals).

[G2]: Dropout group with only classroom training and no internship placement (183 individuals).

[G3]: Dropout group with classroom training and internship placement (231 individuals).

[G4]: Treatment group with the full treatment (578 individuals).

Clustered robust standard errors are in parentheses.

[ $\hat{\beta}_{1}$ ] represents the treatment effect 6 months after the training; with $\left[\hat{\beta}_{2}\right],\left[\hat{\beta}_{3}\right]$ additional effects in the following periods.

The time dimension of the panel consists of four time periods: Nov-99, May-01, Nov-01 and May02. This represents baseline before Projoven, 6 months after Projoven, 12 months after Projoven, and 18 months after Projoven, respectively. In all models the base periods are Nov-99 and May01 . Two base periods are chosen, as the treatment variable takes the value zero for all individuals (treatment and controls) before the programme (Nov-99).

Table 7 is a summary table. Completed regression results are reported in Appendix Tables A15, A16 and A17. 
Table 8.

Pooled two-stage least squares estimates with sample selection correction (Semykina and Wooldridge, 2006). Projoven sixth Public Call effects on monthly wages by level of completion. Heterogeneous treatment over time and endogenous treatment.

\begin{tabular}{cccc}
$\begin{array}{c}\text { Effects } \\
\text { after 6 } \\
\text { months } \\
{\left[\hat{\beta}_{1}\right]}\end{array}$ & $\begin{array}{c}\text { Additional } \\
\text { effects after 12 } \\
\text { months }\end{array}$ & $\begin{array}{c}\text { Additional } \\
\text { effects } \\
\text { after 18 } \\
\text { months }\end{array}$ & $\begin{array}{c}\text { Durbin-Wu- } \\
\text { Hausman test }\end{array}$ \\
\hline$\left.\hat{\beta}_{2}\right]$ & {$\left[\hat{\beta}_{3}\right]$} & \\
\hline
\end{tabular}

A. Effects of Projoven internship placement

$\begin{array}{lcccc}\text { [G3] vs. [G2] } & -0.277 & 0.692 & -0.007 & \chi_{(3)}^{2}=1.25914 \\ & (0.764) & (0.790) & (0.746) & P \text {-val }=0.73886 \\ & & & & \chi_{(3)}^{2}=4.33657 \\ \text { [G4] vs. [G2] } & 0.652 & 0.502 & -0.271 & \text {-val }=0.22734\end{array}$

B. Effects of Projoven internship completion

\begin{tabular}{ccccc} 
[G4] vs. [G3] & $1.051^{*}$ & -0.714 & -0.622 & $\chi_{(3)}^{2}=3.55694$ \\
& $(0.625)$ & $(0.508)$ & $(0.605)$ & $P$-val $=0.31345$ \\
\hline
\end{tabular}

${ }^{*} p<0.10,{ }^{* *} p<0.05, * * * p<0.01$.

[G1]: Control group (992 individuals).

[G2]: Dropout group with only classroom training and no internship placement (183 individuals).

[G3]: Dropout group with classroom training and internship placement (231 individuals).

[G4]: Treatment group with the full treatment (578 individuals).

Clustered robust standard errors are in parentheses.

[ $\hat{\beta}_{1}$ ] represents the treatment effect 6 months after the training; with $\left[\hat{\beta}_{2}\right],\left[\hat{\beta}_{3}\right]$ additional effects in the following periods.

The time dimension of the panel consists of four time periods: Nov-99, May-01, Nov-01, and May-02. This represents baseline before Projoven, 6 months after Projoven, 12 months after Projoven, and 18 months after Projoven, respectively. In all the models, the base periods are Nov99 and May-01. Two base periods are chosen, as the treatment variable takes the value zero for all individuals (treatment and controls) before the programme (Nov-99).

Table 8 is a summary table. Completed regression results are reported in Appendix Tables A15, A16, and A17. 
Table 9.

Linear probability model - random effects estimates. Projoven sixth Public Call effects on overall employment by level of completion. Heterogeneous treatment over time and across individual characteristics.

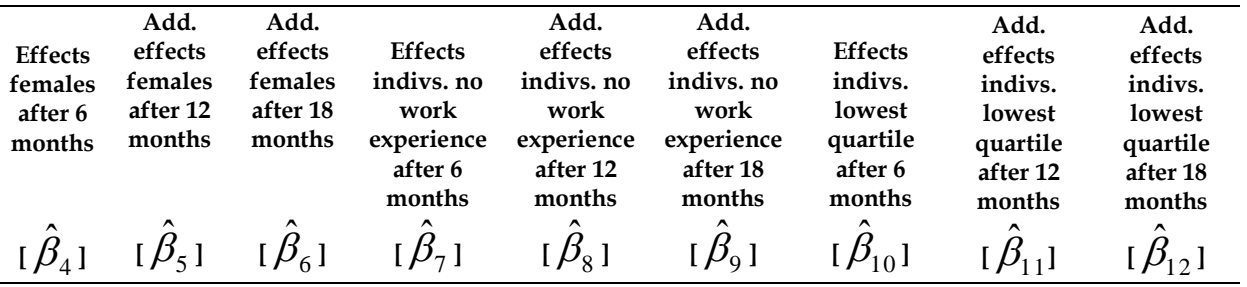

\begin{tabular}{|c|c|c|c|c|c|c|c|c|c|}
\hline \multicolumn{10}{|c|}{ A. Effects of Projoven participation } \\
\hline \multirow[t]{2}{*}{ [G2] vs. [G1] } & -0.079 & 0.084 & 0.011 & $0.167^{* *}$ & -0.01 & 0.003 & -0.013 & -0.052 & -0.01 \\
\hline & $(0.067)$ & $(0.073)$ & $(0.077)$ & $(0.068)$ & $(0.079)$ & $(0.082)$ & $(0.077)$ & $(0.083)$ & $(0.084)$ \\
\hline \multirow[t]{2}{*}{ [G3] vs. [G1] } & $-0.114^{*}$ & 0.100 & 0.084 & $0.148^{* *}$ & -0.074 & 0.085 & 0.012 & -0.026 & -0.055 \\
\hline & $(0.065)$ & $(0.067)$ & $(0.070)$ & $(0.068)$ & $(0.068)$ & $(0.076)$ & $(0.071)$ & $(0.068)$ & $(0.080)$ \\
\hline \multirow[t]{2}{*}{ [G4] vs. [G1] } & $-0.069^{*}$ & -0.013 & 0.000 & $0.243^{* * *}$ & -0.043 & $0.093^{*}$ & 0.029 & 0.023 & 0.007 \\
\hline & $(0.039)$ & $(0.041)$ & $(0.046)$ & $(0.048)$ & $(0.047)$ & $(0.050)$ & $(0.052)$ & $(0.052)$ & $(0.053)$ \\
\hline \multicolumn{10}{|c|}{ B. Effects of Projoven internship placement } \\
\hline \multirow[t]{2}{*}{ [G3] vs. [G2] } & -0.095 & 0.102 & 0.106 & 0.108 & -0.067 & 0.105 & 0.009 & -0.020 & -0.032 \\
\hline & $(0.065)$ & $(0.067)$ & $(0.070)$ & $(0.068)$ & $(0.069)$ & $(0.076)$ & $(0.069)$ & $(0.068)$ & $(0.079)$ \\
\hline \multirow[t]{2}{*}{ [G4] vs. [G2] } & -0.049 & 0.000 & 0.041 & $0.241^{* * *}$ & -0.038 & $0.106^{* *}$ & 0.014 & 0.027 & 0.018 \\
\hline & $(0.039)$ & $(0.042)$ & $(0.045)$ & $(0.048)$ & $(0.048)$ & $(0.050)$ & $(0.051)$ & $(0.052)$ & $(0.053)$ \\
\hline \multicolumn{10}{|c|}{ C. Effects of Projoven internship completion } \\
\hline \multirow[t]{2}{*}{ [G4] vs. [G3] } & -0.051 & 0.01 & 0.056 & $0.282^{* * *}$ & -0.034 & $0.118^{* *}$ & 0.017 & 0.031 & 0.030 \\
\hline & $(0.041)$ & $(0.042)$ & $(0.046)$ & $(0.050)$ & $(0.048)$ & $(0.050)$ & $(0.055)$ & $(0.052)$ & $(0.053)$ \\
\hline
\end{tabular}

${ }^{*} p<0.10,{ }^{* *} p<0.05,{ }^{* * *} p<0.01$.

[G1]: Control group (992 individuals).

[G2]: Dropout group with only classroom training and no internship placement (183 individuals).

[G3]: Dropout group with classroom training and internship placement (231 individuals).

[G4]: Treatment group with the full treatment (578 individuals).

Clustered robust standard errors are in parentheses.

[ $\hat{\beta}_{4}$ ] represents the interactions with the "female" dummy 6 months after the training; with [ $\hat{\beta}_{5}$ ], [ $\left.\hat{\beta}_{6}\right]$ additional effects in the following periods.

[ $\hat{\beta}_{7}$ ] represents the interactions with the "no work experience" dummy 6 months after the training; with $\left[\hat{\beta}_{8}\right],\left[\hat{\beta}_{9}\right]$ additional effects in the following periods.

[ $\hat{\beta}_{10}$ ] represents the interactions with the "lowest quartile" dummy 6 months after the training; with $\left[\hat{\beta}_{11}\right.$ ], [ $\hat{\beta}_{12}$ ] additional effects in the following periods.

The time dimension of the panel consists of four time periods: Nov-99, May-01, Nov-01, and May-02. This represents baseline before Projoven, 6 months after Projoven, 12 months after Projoven and 18 months after Projoven, respectively. In all the models, the base periods are Nov-99 and May-01. Two base periods are chosen, as the treatment variable takes the value zero for all individuals (treatment and controls) before the programme (Nov-99).

Table 9 is a summary table. Completed regression results are reported in Appendix Tables A18, A19 and A24. 
Table 10.

Linear probability model - random effects estimates with sample selection correction. Projoven sixth Public Call effects on formal employment by level of completion. Heterogeneous treatment over time and across individual characteristics.

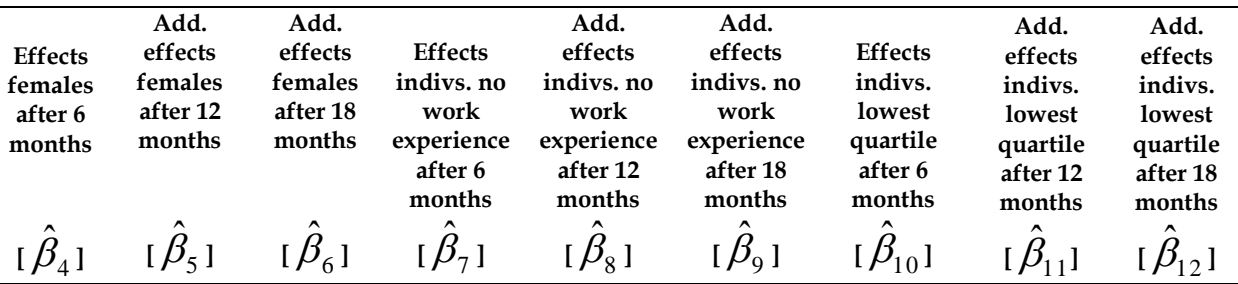

\begin{tabular}{|c|c|c|c|c|c|c|c|c|c|}
\hline \multicolumn{10}{|c|}{ A. Effects of Projoven participation } \\
\hline \multirow[t]{2}{*}{ [G2] vs. [G1] } & -0.105 & 0.008 & 0.046 & 0.021 & -0.090 & 0.089 & 0.031 & 0.003 & 0.003 \\
\hline & $(0.086)$ & $(0.102)$ & $(0.098)$ & $(0.097)$ & $(0.107)$ & $(0.102)$ & $(0.103)$ & $(0.108)$ & $(0.106)$ \\
\hline [G3] vs. [G1] & $(0.087)$ & (0.097) & $(0.086)$ & $(0.098)$ & (0.099) & $(0.095)$ & $(0.088)$ & (0.102) & $(0.078)$ \\
\hline [G4] vs. [G1] & -0.059 & 0.024 & -0.011 & 0.094 & -0.091 & -0.064 & -0.042 & 0.059 & 0.020 \\
\hline \multicolumn{10}{|c|}{ B. Effects of Projoven internship placement } \\
\hline \multirow[t]{2}{*}{ [G3] vs. [G2] } & -0.084 & 0.104 & 0.049 & -0.059 & -0.153 & 0.025 & 0.128 & -0.064 & -0.126 \\
\hline & $(0.091)$ & $(0.095)$ & $(0.088)$ & $(0.102)$ & (0.101) & $(0.097)$ & $(0.097)$ & (0.103) & $(0.080)$ \\
\hline [G4] vs. [G2] & -0.058 & 0.009 & -0.026 & $0.118^{*}$ & -0.099 & -0.071 & -0.058 & 0.053 & -0.007 \\
\hline \multirow[t]{2}{*}{ [G4] vs. [G3] } & $-0.092^{*}$ & 0.025 & -0.033 & 0.085 & -0.103 & -0.078 & 0.009 & 0.046 & 0.002 \\
\hline & $(0.052)$ & $(0.053)$ & $(0.053)$ & $(0.074)$ & $(0.063)$ & $(0.061)$ & $(0.076)$ & $(0.063)$ & $(0.066)$ \\
\hline
\end{tabular}

${ }^{*} p<0.10,{ }^{* *} p<0.05,{ }^{* * *} p<0.01$.

[G1]: Control group (992 individuals).

[G2]: Dropout group with only classroom training and no internship placement (183 individuals).

[G3]: Dropout group with classroom training and internship placement (231 individuals).

[G4]: Treatment group with the full treatment (578 individuals).

Clustered robust standard errors are in parentheses.

[ $\hat{\beta}_{4}$ ] represents the interactions with the "female" dummy 6 months after the training; with [ $\hat{\beta}_{5}$ ], [ $\left.\hat{\beta}_{6}\right]$ additional effects in the following periods.

[ $\hat{\beta}_{7}$ ] represents the interactions with the "no work experience" dummy 6 months after the training; with $\left[\hat{\beta}_{8}\right],\left[\hat{\beta}_{9}\right]$ additional effects in the following periods.

[ $\hat{\beta}_{10}$ ] represents the interactions with the "lowest quartile" dummy 6 months after the training; with $\left[\hat{\beta}_{11}\right.$ ], [ $\hat{\beta}_{12}$ ] additional effects in the following periods.

The time dimension of the panel consists of four time periods: Nov-99, May-01, Nov-01, and May-02. This represents baseline before Projoven, 6 months after Projoven, 12 months after Projoven and 18 months after Projoven, respectively. In all the models the base periods are Nov-99 and May-01. Two base periods are chosen, as the treatment variable takes the value zero for all individuals (treatment and controls) before the programme (Nov-99).

Table 10 is a summary table. Completed regression results are reported in Appendix Tables A20, A22 and A24. 
Table 11.

Random effects estimates with sample selection correction. Projoven sixth Public Call effects on monthly wages by level of completion, conditional on being employed. Heterogeneous treatment over time and across individual characteristics.

\begin{tabular}{|c|c|c|c|c|c|c|c|c|c|}
\hline & $\begin{array}{c}\text { Effects } \\
\text { females } \\
\text { after } 6 \\
\text { months }\end{array}$ & $\begin{array}{c}\text { Add. } \\
\text { effects } \\
\text { females } \\
\text { after } 12 \\
\text { months }\end{array}$ & $\begin{array}{c}\text { Add. } \\
\text { effects } \\
\text { females } \\
\text { after } 18 \\
\text { months }\end{array}$ & $\begin{array}{c}\text { Effects } \\
\text { indivs. no } \\
\text { work } \\
\text { experience } \\
\text { after } 6 \\
\text { months } \\
{\left[\hat{\beta}_{7}\right]}\end{array}$ & $\begin{array}{c}\begin{array}{c}\text { Add. } \\
\text { effects }\end{array} \\
\text { indivs. no } \\
\text { work } \\
\text { experience } \\
\text { after } 12 \\
\text { months } \\
{\left[\hat{\beta}_{8}\right]}\end{array}$ & $\begin{array}{c}\begin{array}{c}\text { Add. } \\
\text { effects }\end{array} \\
\text { indivs. no } \\
\text { work } \\
\text { experience } \\
\text { after } 18 \\
\text { months } \\
{\left[\hat{\beta}_{9}\right]}\end{array}$ & $\begin{array}{c}\text { Effects } \\
\text { indivs. } \\
\text { lowest } \\
\text { quartile } \\
\text { after } 6 \\
\text { months } \\
{\left[\hat{\beta}_{10}\right]}\end{array}$ & $\begin{array}{c}\text { Add. } \\
\text { effects } \\
\text { indivs. } \\
\text { lowest } \\
\text { quartile } \\
\text { after } 12 \\
\text { months } \\
{\left[\hat{\beta}_{11}\right]}\end{array}$ & $\begin{array}{c}\begin{array}{c}\text { Add. } \\
\text { effects }\end{array} \\
\text { indivs. } \\
\text { lowest } \\
\text { quartile } \\
\text { after } 18 \\
\text { months } \\
{\left[\hat{\beta}_{12}\right]}\end{array}$ \\
\hline \multicolumn{10}{|c|}{ A. Effects of Projoven participation } \\
\hline \multirow[t]{2}{*}{ [G2] vs. [G1] } & -0.151 & -0.115 & -0.146 & -0.241 & -0.03 & $0.312^{* *}$ & $0.363^{*}$ & 0.142 & -0.054 \\
\hline & $(0.182)$ & $(0.147)$ & $(0.155)$ & $(0.166)$ & $(0.134)$ & $(0.138)$ & $(0.208)$ & $(0.161)$ & $(0.155)$ \\
\hline & $(0.092)$ & $(0.066)$ & $(0.067)$ & $(0.126)$ & $(0.080)$ & $(0.080)$ & $(0.117)$ & $(0.085)$ & $(0.084)$ \\
\hline \multicolumn{10}{|c|}{ B. Effects of Projoven internship placement } \\
\hline \multirow[t]{2}{*}{ [G3] vs. [G2] } & 0.010 & -0.189 & -0.175 & -0.110 & $0.268^{*}$ & 0.222 & 0.193 & 0.033 & 0.020 \\
\hline & $(0.158)$ & $(0.124)$ & $(0.127)$ & (0.198) & $(0.141)$ & $(0.180)$ & $(0.203)$ & $(0.124)$ & $(0.169)$ \\
\hline \multirow[t]{2}{*}{ [G4] vs. [G2] } & -0.124 & -0.006 & $0.140^{\star *}$ & $0.353^{* * *}$ & -0.002 & 0.042 & $0.482^{* * *}$ & 0.078 & -0.041 \\
\hline & $(0.100)$ & $(0.067)$ & $(0.068)$ & $(0.133)$ & $(0.082)$ & $(0.081)$ & $(0.126)$ & $(0.089)$ & (0.089) \\
\hline \multicolumn{10}{|c|}{ C. Effects of Projoven internship completion } \\
\hline [G4] vs. [G3] & -0.140 & -0.042 & $0.137^{* *}$ & $0.370^{* * *}$ & -0.015 & 0.023 & $0.422^{* * *}$ & 0.098 & -0.025 \\
\hline
\end{tabular}

${ }^{*} p<0.10,{ }^{* *} p<0.05,{ }^{* * *} p<0.01$.

[G1]: Control group (992 individuals).

[G2]: Dropout group with only classroom training and no internship placement (183 individuals).

[G3]: Dropout group with classroom training and internship placement (231 individuals).

[G4]: Treatment group with the full treatment (578 individuals).

Clustered robust standard errors are in parentheses.

$\left[\hat{\beta}_{4}\right]$ represents the interactions with the "female" dummy 6 months after the training; with $\left[\hat{\beta}_{5}\right],\left[\hat{\beta}_{6}\right]$ additional effects in the following periods.

$\left[\hat{\beta}_{7}\right]$ represents the interactions with the "no work experience" dummy 6 months after the training; with $\left[\hat{\beta}_{8}\right],\left[\hat{\beta}_{9}\right]$ additional effects in the following periods.

$\left[\hat{\beta}_{10}\right]$ represents the interactions with the "lowest quartile" dummy 6 months after the training; with $\left[\hat{\beta}_{11}\right]$, $\left[\hat{\beta}_{12}\right]$ additional effects in the following periods.

The time dimension of the panel consists of four time periods: Nov-99, May-01, Nov-01, and May-02. This represents baseline before Projoven, 6 months after Projoven, 12 months after Projoven, and 18 months after Projoven, respectively. In all the models the base periods are Nov-99 and May-01. Two base periods are chosen, as the treatment variable takes the value zero for all individuals (treatment and controls) before the programme (Nov-99).

Table 11 is a summary table. Completed regression results are reported in Appendix Tables A21, A23 and A24. 
Figure 1.

Distribution of trainees by participation level. Projoven sixth Public Call.

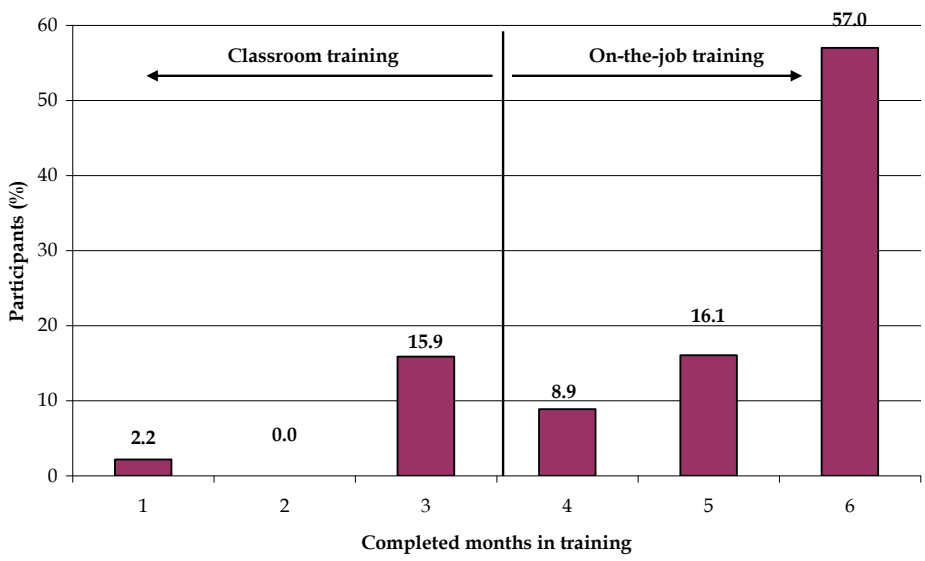

Source: Projoven. Further elaboration by the authors.

\section{Figure 2.}

Evaluation sample. Projoven sixth Public Call.

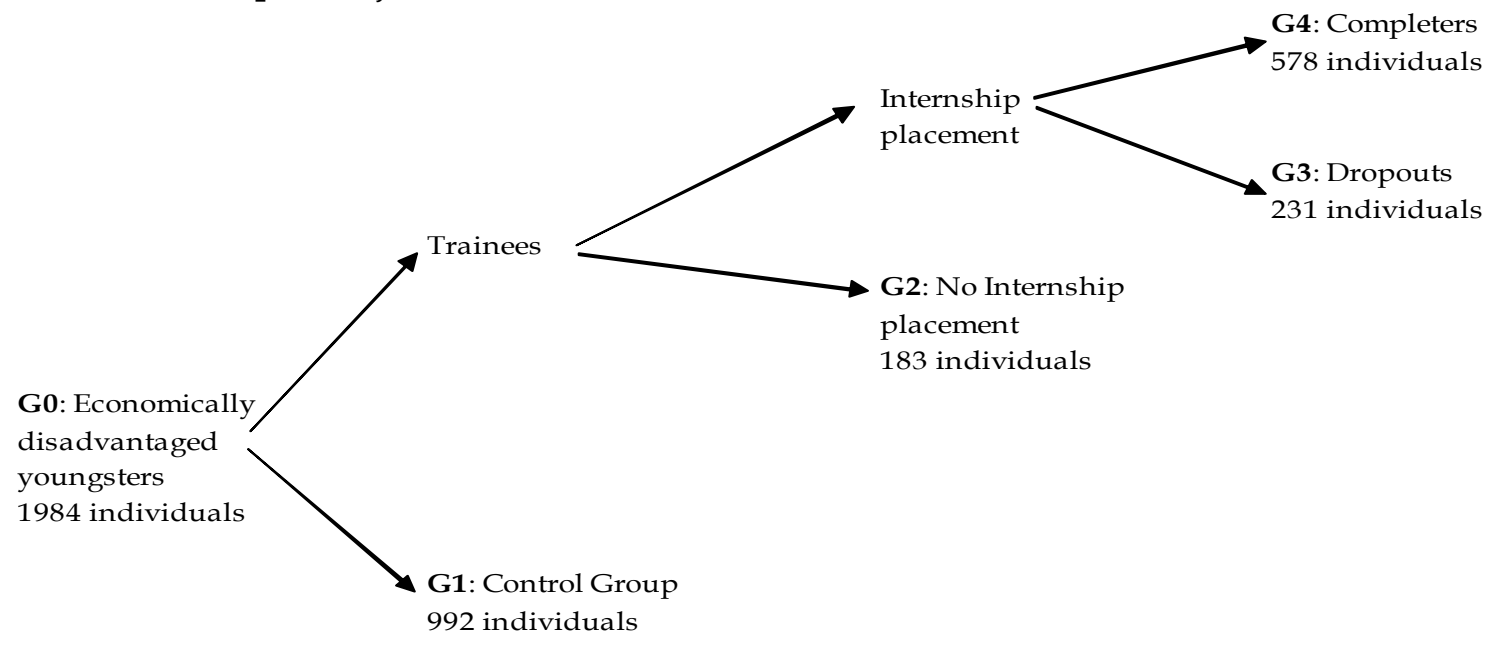

Source: Projoven. Further elaboration by the authors. 


\section{Appendix}

Table A1.

Poverty status index composition.

\begin{tabular}{|c|c|c|c|c|c|c|c|c|}
\hline Item & Category 1 & Score & Category 2 & Score & Category 3 & Score & Category 4 & Score \\
\hline $\begin{array}{l}\text { Household } \\
\text { Floor }\end{array}$ & Land & 4 & Wood & 3 & Cement & 2 & Vinyl & 0 \\
\hline $\begin{array}{l}\text { Household } \\
\text { ceiling }\end{array}$ & Residuals & 4 & Cardboard & 3 & Plastic, wood & 2 & $\begin{array}{l}\text { Cement, } \\
\text { concrete }\end{array}$ & 0 \\
\hline $\begin{array}{l}\text { Household } \\
\text { walls }\end{array}$ & Cardboard & 4 & Wood & 3 & $\begin{array}{l}\text { Brick } \\
\text { uncompleted }\end{array}$ & 2 & $\begin{array}{l}\text { Brick } \\
\text { completed }\end{array}$ & 0 \\
\hline $\begin{array}{l}\text { Source of } \\
\text { Potable water }\end{array}$ & $\begin{array}{l}\text { River or } \\
\text { tanker }\end{array}$ & 4 & Well & 3 & $\begin{array}{l}\text { Outdoor } \\
\text { public } \\
\text { network }\end{array}$ & 1 & $\begin{array}{l}\text { Indoor } \\
\text { public } \\
\text { network }\end{array}$ & 0 \\
\hline Toilet & No toilet & 4 & latrine & 3 & $\begin{array}{l}\text { Outdoor } \\
\text { public } \\
\text { network }\end{array}$ & 2 & $\begin{array}{l}\text { Indoor } \\
\text { public } \\
\text { network }\end{array}$ & 0 \\
\hline Overcrowding 1 & $>=5$ & 4 & $>=4$ and $<5$ & 3 & $>=3$ and $<4$ & 2 & $<3$ & 0 \\
\hline $\begin{array}{l}\text { Household } \\
\text { head education } \\
\text { level }\end{array}$ & $\begin{array}{l}\text { No } \\
\text { education or } \\
\text { uncompleted } \\
\text { primary }\end{array}$ & 4 & $\begin{array}{l}\text { Secondary } \\
\text { education }\end{array}$ & 2 & $\begin{array}{l}\text { Uncompleted } \\
\text { tertiary } \\
\text { education }\end{array}$ & 1 & $\begin{array}{l}\text { Completed } \\
\text { tertiary } \\
\text { education }\end{array}$ & 0 \\
\hline $\begin{array}{l}\text { Dependency } \\
\text { ratio }^{2}\end{array}$ & $>=3$ & 4 & $>=2$ and $<3$ & 2 & $<2$ & 0 & & \\
\hline
\end{tabular}

Source: Burga (2003).

Notes: 1. Ratio household size / number of rooms.

2. Ratio non-working household members / number working household members. 
Table A2.

Common support groups matching methods to conform control group. Projoven sixth Public Call.

\begin{tabular}{llccc}
\hline \multicolumn{1}{c}{ Group } & \multicolumn{1}{c}{ Characteristics } & Control & Participants & Total \\
\hline Group 1 & Arequipa, not employed & 56 & 59 & 115 \\
Group 2 & Chiclayo, not employed & 60 & 48 & 108 \\
Group 3 & Cusco, not employed & 40 & 43 & 83 \\
Group 4 & Lima, not employed & 177 & 170 & 347 \\
Group 5 & Trujillo, not employed & 69 & 74 & 143 \\
Group 6 & Arequipa, income $<=100$ & 47 & 100 & 147 \\
Group 7 & Chiclayo, income $<=100$ & 16 & 31 & 47 \\
Group 8 & Cusco, income $<=100$ & 20 & 26 & 46 \\
Group 9 & Lima, income $<=100$ & 29 & 69 & 98 \\
Group 10 & Trujillo, income $<=100$ & 16 & 39 & 55 \\
Group 11 & Arequipa, 100 $<$ income $<=300$ & 68 & 39 & 107 \\
Group 12 & Chiclayo, 100 $<$ income $<=300$ & 40 & 27 & 67 \\
Group 13 & Cusco, $100<$ income $<=300$ & 38 & 32 & 70 \\
Group 14 & Lima, 100 $<$ income $<=300$ & 86 & 85 & 171 \\
Group 15 & Trujillo, 100 $<$ income $<=300$ & 75 & 46 & 121 \\
Group 16 & Arequipa, income $>300$ & 34 & 7 & 41 \\
Group 17 & Chiclayo, income $>300$ & 6 & 4 & 10 \\
Group 18 & Cusco, income $>300$ & 19 & 16 & 35 \\
Group 19 & Lima, income $>300$ & 76 & 37 & 113 \\
Group 20 & Trujillo, income $>300$ & 42 & 40 & 82 \\
Total & & $\mathbf{1 , 0 1 4}$ & $\mathbf{9 9 2}$ & $\mathbf{2 , 0 0 6}$ \\
\hline
\end{tabular}


Table A3.

Propensity score estimation. Probit model. Dependent variable.: participating in Projoven at baseline [Projoven $=1$ ]. Conditioned on being eligible for the training.

\begin{tabular}{|c|c|c|}
\hline & $\begin{array}{c}\text { Marginal } \\
\text { effects }\end{array}$ & Std. err. \\
\hline Ln hh income per capita & $-0.050^{*}$ & $(0.027)$ \\
\hline Lowest quartile hh income per capita & $0.063^{*}$ & $(0.038)$ \\
\hline Age & $0.014^{* * *}$ & $(0.005)$ \\
\hline Household size & -0.004 & $(0.005)$ \\
\hline Female & 0.000 & $(0.024)$ \\
\hline Married & $-0.171^{* * *}$ & $(0.039)$ \\
\hline Child & -0.060 & $(0.043)$ \\
\hline Years schooling & -0.013 & $(0.009)$ \\
\hline Father tertiary education & $0.071^{*}$ & $(0.040)$ \\
\hline Mother tertiary education & $0.165^{* * *}$ & $(0.060)$ \\
\hline Additional training course & $0.098^{* * *}$ & $(0.027)$ \\
\hline Unemployed/OLF -> employed & 0.008 & $(0.043)$ \\
\hline Employed -> unemployed/OLF & 0.023 & $(0.058)$ \\
\hline $\begin{array}{l}\text { Unemployed/OLF -> } \\
\text { unemployed/OLF }\end{array}$ & $-0.074^{* *}$ & $(0.036)$ \\
\hline No work experience (\%) & $0.175^{* * *}$ & $(0.037)$ \\
\hline Non-wage family business worker & $0.203^{* * *}$ & $(0.038)$ \\
\hline Num observations & \multicolumn{2}{|c|}{2006} \\
\hline Wald $X^{2}(16)$ & \multicolumn{2}{|c|}{151.97} \\
\hline Log likelihood & \multicolumn{2}{|c|}{-1307.72} \\
\hline Pseudo $\mathrm{R}^{2}$ & \multicolumn{2}{|c|}{0.0594} \\
\hline
\end{tabular}

* Statistically significant at $10 \%,{ }^{* *}$ statistically significant at $5 \%,{ }^{* * *}$ statistically significant at $1 \%$. Marginal effects are estimated at the median. 
Table A4.

Baseline OLS estimates. Test of systematic differences prior to training [new control group and treatment individuals sample].

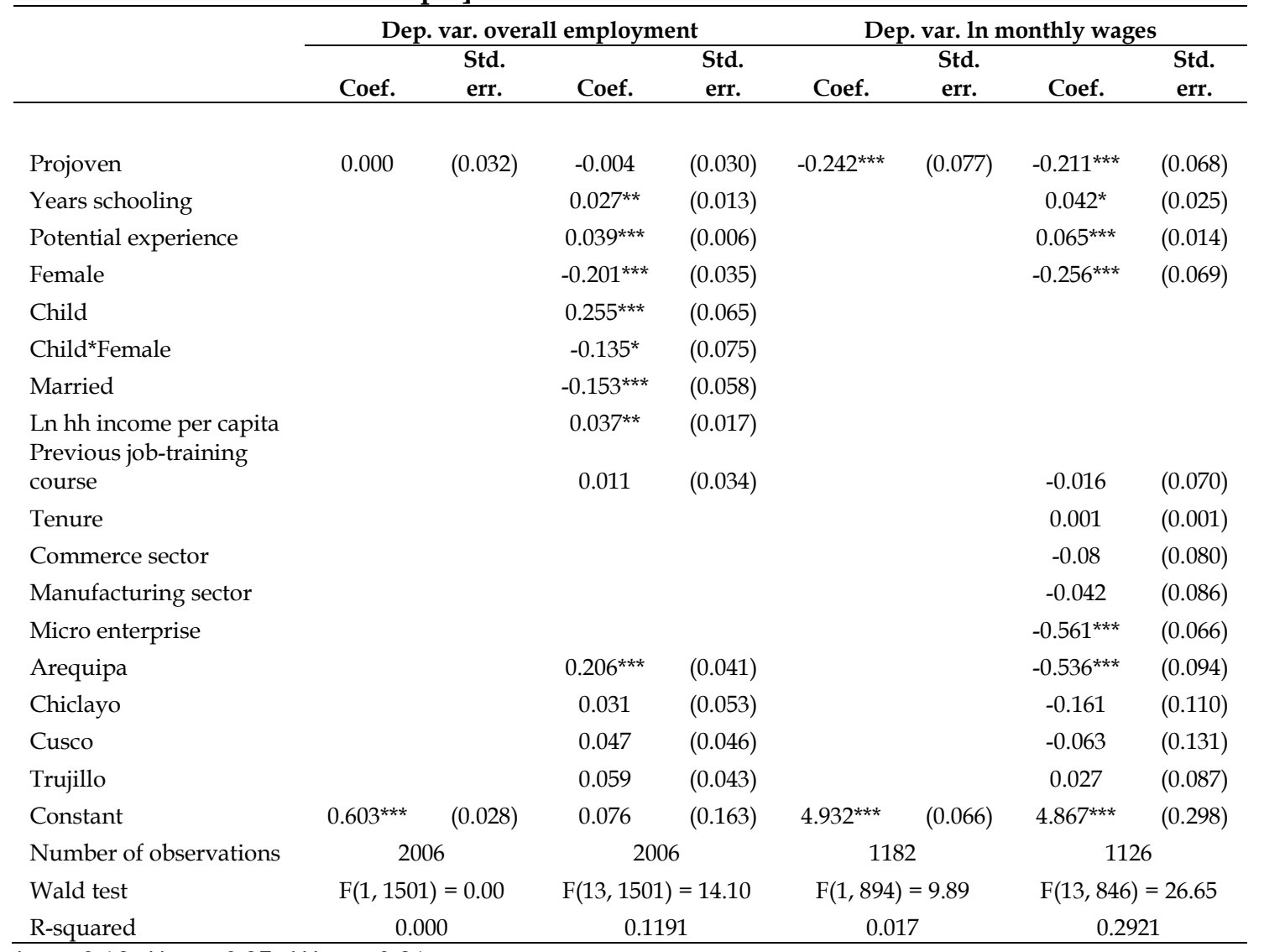

* $p<0.10,{ }^{* *} p<0.05,{ }^{* * *} p<0.01$.

Robust standard errors adjusted.

Base category for city dummies: Lima. 
Table A5.

Rosenbaum (1995) sensitivity analysis for Projoven sixth Public Call effect on employment [6 months after training]. Range of significance levels for hidden biases of various magnitudes.

\begin{tabular}{ccc}
\hline$\Gamma$ & Minimum & Maximum \\
\hline & & \\
1 & $<0.0001$ & $<0.0001$ \\
2 & $<0.0001$ & 0.0078 \\
3 & $<0.0001$ & 0.6848 \\
4 & $<0.0001$ & 0.9924 \\
5 & $<0.0001$ & 0.9999 \\
\hline
\end{tabular}

Values of $\Gamma$ close to 1 could lead to inferences that differ significantly from those obtained assuming the study is free of hidden bias. A study is insensitive if extreme values of $\Gamma$ are required to alter the inference.

Table A4 gives the sensitivity analysis for Projoven sixth Public Call. For five values of $\Gamma$, the table gives the upper and lower bounds on the significance level. If $\Gamma=2$, one person in a pair may be two times as likely to undertake training as the other because they have different values of the unobserved covariate $r$. In the case $\Gamma=2$, the significance level might be less than 0.0001 or it might be as high as 0.0078 , but for all $r \in R$, the null hypothesis of no effect of training on employment is not plausible. The null hypothesis of no effect begins to become plausible for at least some $r \in R$ with $\Gamma=3$. To attribute the higher employment rate to an unobservable covariate rather than to an effect of training, that unobserved covariate would need to produce a threefold increase in the odds of undertaking training, and it would need to be a near-perfect predictor of employment. Consequently, the association between training and employment cannot be attributed to small hidden biases, but is somewhat more sensitive to bias than examples provided in Rosenbaum (1995). ${ }^{21}$

\footnotetext{
${ }^{21}$ Rosenbaum (1995) considers a high degree of insensitivity to hidden bias when the null hypothesis of no effect begins to become plausible for at least $\Gamma=5$.
} 
Table A6.

OLS estimates. Instruments relevance test [only trainees sample].

\begin{tabular}{lcccc} 
& \multicolumn{3}{c}{$\begin{array}{c}\text { Dep. var. ov. } \\
\text { employment }\end{array}$} & \multicolumn{2}{c}{$\begin{array}{c}\text { Dep. var. In monthly } \\
\text { wages }\end{array}$} \\
\cline { 2 - 6 } & Coef. & Std. err. & Coef. & Std. err. \\
\hline Type of Ecap & & & & \\
$\quad$ Centres for vocational training [CEO] & 0.026 & $(0.052)$ & 0.124 & $(0.126)$ \\
$\quad$ Firms & -0.071 & $(0.082)$ & -0.034 & $(0.211)$ \\
Institutes for tertiary technical education [IST] & 0.142 & $(0.097)$ & $-0.290^{* *}$ & $(0.184)$ \\
NGO & 0.019 & $(0.051)$ & -0.065 & $(0.123)$ \\
Vocational centres sponsored by guilds [Guilds] & -0.003 & $(0.053)$ & 0.07 & $(0.126)$ \\
$\quad$ University & -0.079 & $(0.060)$ & -0.116 & $(0.146)$ \\
Constant & $0.648^{* * *}$ & $(0.050)$ & $5.409^{* * *}$ & $(0.120)$ \\
Number of observations & \multicolumn{2}{c}{4056} & \multicolumn{2}{c}{2500} \\
F-test & \multicolumn{2}{c}{$\mathrm{F}(6,4049)=5.59$} & $\mathrm{~F}(6,2493)=7.46$ \\
$\mathrm{R}^{2}$ & \multicolumn{2}{c}{0.0067} & \multicolumn{3}{c}{0.0153} \\
\hline
\end{tabular}

${ }^{*} p<0.10,{ }^{* *} p<0.05$, *** $p<0.01$.

Base category for ECAP-type dummies: others (high schools, churches, etc.).

Robust standard errors.

Table A7.

OLS estimates. Instruments relevance test [only trainees placed in internship sample].

\begin{tabular}{|c|c|c|c|c|}
\hline & \multicolumn{2}{|c|}{$\begin{array}{l}\text { Dep. var. ov. } \\
\text { employment }\end{array}$} & \multicolumn{2}{|c|}{$\begin{array}{c}\text { Dep. var. ln monthly } \\
\text { wages }\end{array}$} \\
\hline & Coef. & Std. err. & Coef. & Std. err. \\
\hline \multicolumn{5}{|l|}{ Type of Ecap } \\
\hline Centres for vocational training [CEO] & -0.024 & $(0.067)$ & 0.169 & $(0.154)$ \\
\hline Firms & -0.115 & $(0.092)$ & -0.006 & $(0.227)$ \\
\hline Institutes for tertiary technical education [IST] & 0.091 & $(0.075)$ & -0.265 & $(0.170)$ \\
\hline NGO & -0.001 & $(0.066)$ & 0.024 & $(0.151)$ \\
\hline Vocational centres sponsored by guilds [Guilds] & -0.04 & $(0.068)$ & 0.114 & $(0.157)$ \\
\hline University & $-0.151^{* *}$ & $(0.076)$ & -0.056 & $(0.179)$ \\
\hline Constant & $0.692^{* * *}$ & $(0.065)$ & $5.381^{* * *}$ & $(0.148)$ \\
\hline Number of observations & \multicolumn{2}{|c|}{2832} & \multicolumn{2}{|c|}{1772} \\
\hline F-test & \multicolumn{2}{|c|}{$F(6,2825)=4.14$} & \multicolumn{2}{|c|}{$F(6,1765)=4.32$} \\
\hline $\mathrm{R}^{2}$ & \multicolumn{2}{|c|}{0.0087} & \multicolumn{2}{|c|}{0.0145} \\
\hline
\end{tabular}

${ }^{*} p<0.10,{ }^{* *} p<0.05, * * * \quad p<0.01$.

Base category for ECAP-type dummies: others (high schools, churches, etc.).

Robust standard errors. 
Table A8.

LPM-FE estimates Projoven sixth Public Call participation effects on overall employment. Heterogeneous effects over time.

\begin{tabular}{|c|c|c|c|c|c|c|}
\hline & \multicolumn{2}{|c|}{ [G2] vs. [G1] } & \multicolumn{2}{|c|}{ [G3] vs. [G1] } & \multicolumn{2}{|c|}{ [G4] vs. [G1] } \\
\hline & Coef. & $\begin{array}{l}\text { Std. } \\
\text { err. }\end{array}$ & Coef. & $\begin{array}{l}\text { Std. } \\
\text { err. }\end{array}$ & Coef. & $\begin{array}{l}\text { Std. } \\
\text { err. }\end{array}$ \\
\hline Projoven & 0.033 & $(0.059)$ & -0.006 & $(0.054)$ & $0.091^{* *}$ & $(0.044)$ \\
\hline Projoven [12 months] & -0.036 & $(0.051)$ & -0.068 & $(0.045)$ & $-0.105^{* * *}$ & $(0.036)$ \\
\hline Projoven [18 months] & -0.069 & $(0.056)$ & -0.018 & $(0.054)$ & $-0.125^{* * *}$ & $(0.043)$ \\
\hline Years schooling & -0.014 & $(0.044)$ & -0.028 & $(0.044)$ & -0.027 & $(0.041)$ \\
\hline Potential experience & -0.028 & $(0.035)$ & -0.027 & $(0.035)$ & -0.027 & $(0.035)$ \\
\hline Child & 0.013 & $(0.088)$ & -0.042 & $(0.088)$ & -0.059 & $(0.075)$ \\
\hline Child*Female & -0.042 & $(0.115)$ & -0.032 & $(0.116)$ & -0.011 & $(0.097)$ \\
\hline Married & -0.061 & $(0.045)$ & -0.047 & $(0.044)$ & -0.049 & $(0.039)$ \\
\hline Ln hh income per capita & $-0.013^{* *}$ & $(0.005)$ & $-0.014^{\star * *}$ & $(0.005)$ & $-0.014^{* * *}$ & $(0.004)$ \\
\hline $\begin{array}{l}\text { Previous job-training } \\
\text { course }\end{array}$ & $-0.055^{*}$ & $(0.031)$ & $-0.067^{* *}$ & $(0.030)$ & -0.037 & $(0.025)$ \\
\hline Constant & 0.914 & $(0.575)$ & $1.078^{*}$ & $(0.574)$ & $1.068^{* *}$ & $(0.537)$ \\
\hline Time Dummies & \multicolumn{2}{|c|}{ yes } & \multicolumn{2}{|c|}{ yes } & \multicolumn{2}{|c|}{ yes } \\
\hline Number of observations & \multicolumn{2}{|c|}{4724} & \multicolumn{2}{|c|}{4827} & \multicolumn{2}{|c|}{6257} \\
\hline Number of individuals & \multicolumn{2}{|c|}{1186} & \multicolumn{2}{|c|}{1212} & \multicolumn{2}{|c|}{1570} \\
\hline F-test & \multicolumn{2}{|c|}{$\mathrm{F}(12,681)=8.71$} & \multicolumn{2}{|c|}{$\mathrm{F}(12,707)=10.65$} & \multicolumn{2}{|c|}{$\mathrm{F}(12,1065)=12.33$} \\
\hline R-squared & \multicolumn{2}{|c|}{0.071} & \multicolumn{2}{|c|}{0.0766} & \multicolumn{2}{|c|}{0.0632} \\
\hline $\operatorname{corr}\left(\eta_{i}, X_{i t} \alpha\right)$ & \multicolumn{2}{|c|}{-0.218} & \multicolumn{2}{|c|}{-0.2292} & \multicolumn{2}{|c|}{-0.2435} \\
\hline
\end{tabular}

${ }^{*} p<0.10,{ }^{* *} p<0.05,{ }^{* * *} p<0.01$.

[G1]: Control group (992 individuals).

[G2]: Dropout group with only classroom training and no internship placement (183 individuals).

[G3]: Dropout group with classroom training and internship placement (231 individuals).

[G4]: Treatment group with the full treatment (578 individuals).

The time dimension of the panel consists of four time periods: Nov-99, May-01, Nov-01, and May-02. This represents baseline before Projoven, 6 months after Projoven, 12 months after Projoven, and 18 months after Projoven, respectively. In all the models the base periods are Nov99 and May-01. Two base periods are chosen, as the treatment variable takes the value zero for all individuals (treatment and controls) before the programme (Nov-99).

Clustered robust standard errors. 
Table A9.

LPM-FE estimates Projoven sixth Public Call internship placement effects on overall employment. Heterogeneous effects over time [only trainees sample].

\begin{tabular}{|c|c|c|c|c|}
\hline & \multicolumn{2}{|c|}{ [G3] vs. [G2] } & \multicolumn{2}{|c|}{ [G4] vs. [G2] } \\
\hline & Coef. & $\begin{array}{l}\text { Std. } \\
\text { err. }\end{array}$ & Coef. & $\begin{array}{l}\text { Std. } \\
\text { err. }\end{array}$ \\
\hline Internship & -0.041 & $(0.062)$ & 0.055 & $(0.054)$ \\
\hline Internship [12 months] & -0.033 & $(0.056)$ & -0.063 & $(0.048)$ \\
\hline Internship [18 months] & 0.051 & $(0.057)$ & -0.049 & $(0.048)$ \\
\hline Years schooling & 0.060 & $(0.051)$ & 0.033 & $(0.049)$ \\
\hline Potential experience & 0.002 & $(0.047)$ & 0.009 & $(0.047)$ \\
\hline Child & 0.150 & $(0.100)$ & 0.042 & $(0.065)$ \\
\hline Child*Female & $-0.277^{*}$ & $(0.155)$ & -0.123 & $(0.092)$ \\
\hline Married & $-0.211^{* * *}$ & $(0.066)$ & $-0.141^{* * *}$ & $(0.051)$ \\
\hline Ln hh income per capita & $-0.016^{* *}$ & $(0.008)$ & $-0.015^{* * *}$ & $(0.004)$ \\
\hline $\begin{array}{l}\text { Previous job-training } \\
\text { course }\end{array}$ & $-0.129 * * *$ & $(0.037)$ & -0.040 & $(0.026)$ \\
\hline Constant & 0.086 & $(0.683)$ & 0.332 & $(0.665)$ \\
\hline Time Dummies & \multicolumn{2}{|c|}{ yes } & \multicolumn{2}{|c|}{ yes } \\
\hline Number of observations & \multicolumn{2}{|c|}{1653} & \multicolumn{2}{|c|}{3083} \\
\hline Number of individuals & \multicolumn{2}{|c|}{414} & \multicolumn{2}{|c|}{772} \\
\hline F-test & \multicolumn{2}{|c|}{$F(12,413)=9.60$} & \multicolumn{2}{|c|}{$F(12,771)=9.91$} \\
\hline R-squared & \multicolumn{2}{|c|}{0.077} & \multicolumn{2}{|c|}{0.0451} \\
\hline $\operatorname{corr}\left(\eta_{i}, X_{i t} \alpha\right)$ & \multicolumn{2}{|c|}{-0.1813} & \multicolumn{2}{|c|}{-0.019} \\
\hline
\end{tabular}

${ }^{*} p<0.10,{ }^{* *} p<0.05,{ }^{* * *} p<0.01$.

SSC stands for sample selection correction.

[G2]: Dropout group with only classroom training and no internship placement (183 individuals).

[G3]: Dropout group with classroom training and internship placement (231 individuals).

[G4]: Treatment group with the full treatment (578 individuals).

The time dimension of the panel consists of four time periods: Nov-99, May-01, Nov-01, and May-02. This represents baseline before Projoven, 6 months after Projoven, 12 months after Projoven, and 18 months after Projoven, respectively. In all the models, the base periods are Nov99 and May-01. Two base periods are chosen, as the treatment variable takes the value zero for all individuals (treatment and controls) before the programme (Nov-99).

Robust standard errors adjusted for ECAPs clusters. The standard errors should be interpreted as asymptotic lower bounds. 
Table A10.

FE estimates [with sample selection correction - Wooldridge, 1995] Projoven sixth Public Call internship completion effects. Heterogeneous treatment over time [only trainees placed in internships sample] [G4] vs. [G3].

\begin{tabular}{|c|c|c|c|c|c|c|}
\hline & \multicolumn{2}{|c|}{$\begin{array}{c}\text { Dep. var. ov. } \\
\text { employment [LPM] }\end{array}$} & \multicolumn{2}{|c|}{$\begin{array}{l}\text { Dep. var. formal } \\
\text { employment [LPM } \\
\text { with SSC] }\end{array}$} & \multicolumn{2}{|c|}{$\begin{array}{c}\text { Dep. var. In monthly } \\
\text { wages [with SSC] }\end{array}$} \\
\hline & Coef. & Std. err. & Coef. & Std. err. & Coef. & Std. err. \\
\hline Internship Completion & $0.103^{*}$ & $(0.061)$ & $0.187^{*}$ & $(0.097)$ & $0.351^{* *}$ & $(0.139)$ \\
\hline Internship Completion * [12 months] & -0.014 & $(0.051)$ & -0.014 & $(0.077)$ & $-0.263^{* *}$ & $(0.110)$ \\
\hline Internship Completion * [18 months] & $-0.109^{*}$ & $(0.059)$ & -0.029 & $(0.071)$ & $-0.354^{\star * *}$ & $(0.112)$ \\
\hline Years schooling & -0.031 & $(0.058)$ & -0.068 & $(0.102)$ & 0.22 & $(0.150)$ \\
\hline Potential experience & -0.035 & $(0.055)$ & -0.053 & $(0.096)$ & 0.217 & $(0.143)$ \\
\hline Child & -0.1 & $(0.066)$ & 0.110 & $(0.100)$ & & \\
\hline Child*Female & -0.067 & $(0.088)$ & -0.170 & $(0.141)$ & & \\
\hline Married & $-0.093^{*}$ & $(0.053)$ & 0.029 & $(0.070)$ & & \\
\hline Ln hh income per capita & $-0.017^{* * *}$ & $(0.004)$ & 0.002 & $(0.007)$ & & \\
\hline Previous job-training course & $-0.050^{*}$ & $(0.027)$ & 0.002 & $(0.035)$ & $-0.145^{* * *}$ & $(0.054)$ \\
\hline Commerce sector & & & -0.025 & $(0.043)$ & -0.079 & $(0.071)$ \\
\hline Manufacturing sector & & & $0.081^{* *}$ & $(0.041)$ & 0.01 & $(0.062)$ \\
\hline Micro enterprise & & & $-0.140^{* * *}$ & $(0.031)$ & $-0.443^{* * *}$ & $(0.051)$ \\
\hline Constant & 1.163 & $(0.776)$ & 1.506 & $(1.382)$ & 2.067 & $(2.054)$ \\
\hline Time Dummies & \multicolumn{2}{|c|}{ yes } & \multicolumn{2}{|c|}{ yes } & \multicolumn{2}{|c|}{ yes } \\
\hline SSC terms & \multicolumn{2}{|c|}{ no } & \multicolumn{2}{|c|}{ yes } & \multicolumn{2}{|c|}{ yes } \\
\hline Number of observations & \multicolumn{2}{|c|}{2827} & \multicolumn{2}{|c|}{1908} & \multicolumn{2}{|c|}{1772} \\
\hline Number of individuals & \multicolumn{2}{|c|}{708} & \multicolumn{2}{|c|}{679} & \multicolumn{2}{|c|}{646} \\
\hline Overall F-test & \multicolumn{2}{|c|}{$\mathrm{F}(12,2815)=10.27$} & \multicolumn{2}{|c|}{$F(19,1888)=3.56$} & \multicolumn{2}{|c|}{$F(15,1757)=27.70$} \\
\hline F-Test SSC terms & & & \multicolumn{2}{|c|}{$F(4,678)=1.50$} & \multicolumn{2}{|c|}{$F(4,645)=15.06$} \\
\hline$p$-value & & & \multicolumn{2}{|c|}{0.2004} & \multicolumn{2}{|c|}{0.000} \\
\hline R-squared & \multicolumn{2}{|c|}{0.0512} & \multicolumn{2}{|c|}{0.0573} & \multicolumn{2}{|c|}{0.3755} \\
\hline $\operatorname{corr}\left(\eta_{i}, X_{i t} \alpha\right)$ & \multicolumn{2}{|c|}{-0.389} & \multicolumn{2}{|c|}{-0.3779} & \multicolumn{2}{|c|}{-0.4174} \\
\hline
\end{tabular}

SSC stands for sample selection correction.

[G3]: Dropout group with classroom training and internship placement (231 individuals).

[G4]: Treatment group with the full treatment (578 individuals).

The time dimension of the panel consists of four time periods: Nov-99, May-01, Nov-01 and May02. This represents baseline before Projoven, 6 months after Projoven, 12 months after Projoven, and 18 months after Projoven, respectively. In all the models, the base periods are Nov-99 and May-01. Two base periods are chosen, as the treatment variable takes the value zero for all individuals (treatment and controls) before the programme (Nov-99).

Robust standard errors adjusted for ECAPs clusters. The standard errors should be interpreted as asymptotic lower bounds. 
Table A11.

LPM-FE estimates [corrected for sample selection - Wooldridge, 1995] Projoven sixth Public Call participation effects on formal employment. Heterogeneous effects over time.

\begin{tabular}{|c|c|c|c|c|c|c|c|c|}
\hline & \multicolumn{2}{|c|}{$\begin{array}{c}\text { [G2], [G3] and } \\
\text { [G4] vs. [G1] }\end{array}$} & \multicolumn{2}{|c|}{ [G2] vs. [G1] } & \multicolumn{2}{|c|}{ [G3] vs. [G1] } & \multicolumn{2}{|c|}{ [G4] vs. [G1] } \\
\hline & Coef. & $\begin{array}{l}\text { Std. } \\
\text { err. }\end{array}$ & Coef. & $\begin{array}{l}\text { Std. } \\
\text { err. }\end{array}$ & Coef. & $\begin{array}{l}\text { Std. } \\
\text { err. }\end{array}$ & Coef. & $\begin{array}{l}\text { Std. } \\
\text { err. }\end{array}$ \\
\hline Projoven & 0.028 & $(0.059)$ & -0.046 & $(0.085)$ & 0.012 & $(0.075)$ & 0.081 & $(0.065)$ \\
\hline Projoven [12 months] & -0.006 & $(0.043)$ & -0.020 & $(0.070)$ & -0.011 & $(0.055)$ & -0.010 & $(0.047)$ \\
\hline Projoven [18 months] & $-0.081^{*}$ & $(0.046)$ & $-0.123^{*}$ & $(0.069)$ & -0.078 & $(0.058)$ & -0.071 & $(0.049)$ \\
\hline Years schooling & 0.085 & $(0.065)$ & 0.084 & $(0.079)$ & 0.078 & $(0.050)$ & 0.076 & $(0.070)$ \\
\hline Potential experience & 0.075 & $(0.058)$ & 0.068 & $(0.066)$ & $0.046^{*}$ & $(0.028)$ & 0.076 & $(0.061)$ \\
\hline Child & 0.061 & $(0.067)$ & 0.068 & $(0.090)$ & 0.068 & $(0.090)$ & 0.070 & $(0.080)$ \\
\hline Child*Female & $-0.155^{*}$ & $(0.088)$ & $-0.213^{*}$ & $(0.114)$ & -0.182 & $(0.115)$ & $-0.218^{* *}$ & $(0.097)$ \\
\hline Married & 0.012 & $(0.048)$ & -0.018 & $(0.069)$ & -0.009 & $(0.065)$ & 0.009 & $(0.055)$ \\
\hline Ln hh income per capita & 0.000 & $(0.006)$ & -0.002 & $(0.009)$ & 0.000 & $(0.008)$ & -0.002 & $(0.006)$ \\
\hline Previous job-training course & -0.043 & $(0.033)$ & -0.069 & $(0.050)$ & -0.051 & $(0.050)$ & $-0.064^{*}$ & $(0.038)$ \\
\hline Commerce sector & 0.043 & $(0.033)$ & $0.079^{*}$ & $(0.046)$ & 0.041 & $(0.045)$ & 0.043 & $(0.038)$ \\
\hline Manufacturing sector & 0.021 & $(0.036)$ & -0.024 & $(0.057)$ & -0.063 & $(0.056)$ & 0.011 & $(0.043)$ \\
\hline Micro enterprise & $-0.050^{*}$ & $(0.027)$ & 0.013 & $(0.043)$ & 0.001 & $(0.043)$ & -0.033 & $(0.032)$ \\
\hline Constant & -0.565 & $(0.878)$ & -0.561 & $(1.056)$ & -0.409 & $(0.609)$ & -0.484 & $(0.949)$ \\
\hline Time Dummies & \multicolumn{2}{|c|}{ yes } & \multicolumn{2}{|c|}{ yes } & \multicolumn{2}{|c|}{ yes } & \multicolumn{2}{|c|}{ yes } \\
\hline SSC terms & \multicolumn{2}{|c|}{ yes } & \multicolumn{2}{|c|}{ yes } & \multicolumn{2}{|c|}{ yes } & \multicolumn{2}{|c|}{ yes } \\
\hline Number of observations & \multicolumn{2}{|c|}{5279} & \multicolumn{2}{|c|}{3118} & \multicolumn{2}{|c|}{3183} & \multicolumn{2}{|c|}{4232} \\
\hline Number of individuals & \multicolumn{2}{|c|}{1908} & \multicolumn{2}{|c|}{1141} & \multicolumn{2}{|c|}{1172} & \multicolumn{2}{|c|}{1521} \\
\hline Overall F-test & \multicolumn{2}{|c|}{$F(19,1435)=2.57$} & \multicolumn{2}{|c|}{$F(19,647)=2.89$} & \multicolumn{2}{|c|}{$\mathrm{F}(18,678)=1.92$} & \multicolumn{2}{|c|}{$\mathrm{F}(19,1027)=2.54$} \\
\hline F-test SSC terms & \multicolumn{2}{|c|}{$F(4,1435)=2.28$} & \multicolumn{2}{|c|}{$F(4,647)=2.13$} & \multicolumn{2}{|c|}{$F(4,678)=2.66$} & \multicolumn{2}{|c|}{$\mathrm{F}(4,1027)=1.34$} \\
\hline$p$-value & \multicolumn{2}{|c|}{0.0588} & \multicolumn{2}{|c|}{0.0761} & \multicolumn{2}{|c|}{0.032} & \multicolumn{2}{|c|}{0.2532} \\
\hline R-squared & & & & & & & & \\
\hline $\operatorname{corr}\left(\eta_{i}, X_{i t} \alpha\right)$ & & & & & & & & \\
\hline
\end{tabular}

${ }^{*} p<0.10,{ }^{* *} p<0.05,{ }^{* * *} p<0.01$

SSC stands for sample selection correction.

[G1]: Control group (992 individuals).

[G2]: Dropout group with only classroom training and no internship placement (183 individuals).

[G3]: Dropout group with classroom training and internship placement (231 individuals).

[G4]: Treatment group with the full treatment (578 individuals).

The time dimension of the panel consists of four time periods: Nov-99, May-01, Nov-01, and May-02. This represents baseline before Projoven, 6 months after Projoven, 12 months after Projoven, and 18 months after Projoven, respectively. In all the models, the base periods are Nov99 and May-01. Two base periods are chosen, as the treatment variable takes the value zero for all individuals (treatment and controls) before the programme (Nov-99).

Clustered robust standard errors. The standard errors should be interpreted as asymptotic lower bounds. 
Table A12.

LPM-FE estimates [corrected for sample selection - Wooldridge, 1995] Projoven sixth Public Call internship effects on formal employment. Heterogeneous effects over time [only trainees sample].

\begin{tabular}{|c|c|c|c|c|}
\hline & \multicolumn{2}{|c|}{ [G3] vs. [G2] } & \multicolumn{2}{|c|}{ [G4] vs. [G2] } \\
\hline & Coef. & $\begin{array}{l}\text { Std. } \\
\text { err. }\end{array}$ & Coef. & $\begin{array}{l}\text { Std. } \\
\text { err. }\end{array}$ \\
\hline Internship & 0.032 & $(0.094)$ & 0.092 & $(0.076)$ \\
\hline Internship [12 months] & 0.031 & $(0.077)$ & 0.048 & $(0.067)$ \\
\hline Internship [18 months] & 0.036 & $(0.074)$ & 0.067 & $(0.063)$ \\
\hline Years schooling & 0.083 & $(0.087)$ & 0.062 & $(0.079)$ \\
\hline Potential experience & 0.032 & $(0.082)$ & 0.072 & $(0.075)$ \\
\hline Child & 0.058 & $(0.124)$ & 0.043 & $(0.091)$ \\
\hline Child*Female & 0.175 & $(0.175)$ & -0.116 & $(0.134)$ \\
\hline Married & -0.04 & $(0.095)$ & 0.033 & $(0.069)$ \\
\hline Ln hh income per capita & 0.004 & $(0.011)$ & -0.001 & $(0.007)$ \\
\hline $\begin{array}{l}\text { Previous job-training } \\
\text { course }\end{array}$ & 0.048 & $(0.050)$ & -0.029 & $(0.034)$ \\
\hline Commerce sector & 0.046 & $(0.058)$ & 0.025 & $(0.042)$ \\
\hline Manufacturing sector & 0.059 & $(0.057)$ & $0.100^{* * *}$ & $(0.039)$ \\
\hline Micro enterprise & $-0.115^{* * *}$ & $(0.044)$ & $-0.121^{* * *}$ & $(0.030)$ \\
\hline Constant & -0.409 & $(1.201)$ & -0.289 & $(1.078)$ \\
\hline Time Dummies & \multicolumn{2}{|c|}{ yes } & \multicolumn{2}{|c|}{ yes } \\
\hline SSC terms & \multicolumn{2}{|c|}{ yes } & \multicolumn{2}{|c|}{ yes } \\
\hline Number of observations & \multicolumn{2}{|c|}{1047} & \multicolumn{2}{|c|}{2096} \\
\hline Number of individuals & \multicolumn{2}{|c|}{387} & \multicolumn{2}{|c|}{736} \\
\hline Overall F-test & \multicolumn{2}{|c|}{$F(19,386)=1.58$} & \multicolumn{2}{|c|}{$F(19,735)=3.49$} \\
\hline F-test SSC terms & \multicolumn{2}{|c|}{$F(4,386)=2.90$} & \multicolumn{2}{|c|}{$F(4,735)=2.09$} \\
\hline$p$-value & \multicolumn{2}{|c|}{0.022} & \multicolumn{2}{|c|}{0.0799} \\
\hline R-squared & \multicolumn{2}{|c|}{0.0438} & \multicolumn{2}{|c|}{0.0524} \\
\hline $\operatorname{corr}\left(\eta_{i}, X_{i t} \alpha\right)$ & \multicolumn{2}{|c|}{-0.132} & \multicolumn{2}{|c|}{-0.3913} \\
\hline
\end{tabular}

${ }^{*} p<0.10,{ }^{* *} p<0.05$, *** $p<0.01$.

SSC stands for Sample selection correction.

[G2]: Dropout group with only classroom training and no internship placement (183 individuals).

[G3]: Dropout group with classroom training and internship placement (231 individuals).

[G4]: Treatment group with the full treatment (578 individuals).

The time dimension of the panel consists of four time periods: Nov-99, May-01, Nov-01, and May-02. This represents baseline before Projoven, 6 months after Projoven, 12 months after Projoven, and 18 months after Projoven, respectively. In all the models, the base periods are Nov99 and May-01. Two base periods are chosen, as the treatment variable takes the value zero for all individuals (treatment and controls) before the programme (Nov-99).

Robust standard errors adjusted for ECAPs clusters. The standard errors should be interpreted as asymptotic lower bounds. 
Table A13.

FE estimates [with sample selection correction - Wooldridge, 1995] Projoven sixth Public Call participation effects on monthly wages. Heterogeneous effects over time.

\begin{tabular}{|c|c|c|c|c|c|c|c|c|}
\hline & \multicolumn{2}{|c|}{$\begin{array}{c}\text { [G2], [G3] and } \\
{[\mathrm{G} 4] \text { vs. [G1] }}\end{array}$} & \multicolumn{2}{|c|}{ [G2] vs. [G1] } & \multicolumn{2}{|c|}{ [G3] vs. [G1] } & \multicolumn{2}{|c|}{ [G4] vs. [G1] } \\
\hline & Coef. & $\begin{array}{l}\text { Std. } \\
\text { err. }\end{array}$ & Coef. & $\begin{array}{l}\text { Std. } \\
\text { err. }\end{array}$ & Coef. & $\begin{array}{l}\text { Std. } \\
\text { err. }\end{array}$ & Coef. & $\begin{array}{l}\text { Std. } \\
\text { err. }\end{array}$ \\
\hline Projoven & $0.363^{* * *}$ & $(0.087)$ & 0.332 & $(0.135)$ & $0.341^{* * *}$ & $(0.124)$ & $0.382^{* * *}$ & $(0.095)$ \\
\hline Projoven [12 months] & -0.071 & $(0.059)$ & -0.025 & $(0.096)$ & 0.106 & $(0.084)$ & $-0.140^{* *}$ & $(0.063)$ \\
\hline Projoven [18 months] & -0.002 & $(0.063)$ & 0.105 & $(0.098)$ & 0.126 & $(0.095)$ & -0.089 & $(0.066)$ \\
\hline Years schooling & $0.172^{*}$ & $(0.093)$ & 0.162 & $(0.109)$ & $0.200^{*}$ & $(0.109)$ & $0.177^{*}$ & $(0.104)$ \\
\hline Potential experience & $0.175^{* *}$ & $(0.084)$ & 0.176 & $(0.091)$ & $0.190^{* *}$ & $(0.091)$ & $0.193^{* *}$ & $(0.094)$ \\
\hline Previous job-training course & $-0.100^{* *}$ & $(0.048)$ & -0.061 & $(0.075)$ & -0.074 & $(0.075)$ & -0.091 & $(0.058)$ \\
\hline Commerce sector & -0.036 & $(0.057)$ & -0.035 & $(0.085)$ & 0.015 & $(0.085)$ & -0.016 & $(0.071)$ \\
\hline Manufacturing sector & $\begin{array}{c}0.071 \\
-\end{array}$ & $(0.049)$ & 0.113 & $(0.078)$ & 0.105 & $(0.076)$ & $0.113^{*}$ & $(0.059)$ \\
\hline Micro enterprise & $0.296^{* * *}$ & $(0.044)$ & -0.206 & $(0.068)$ & $-0.198^{* * *}$ & $(0.069)$ & $-0.300^{* * *}$ & $(0.054)$ \\
\hline Constant & $2.627^{* *}$ & $(1.267)$ & 2.710 & $(1.461)$ & 2.229 & $(1.459)$ & $2.504^{*}$ & $(1.442)$ \\
\hline Time Dummies & \multicolumn{2}{|c|}{ yes } & \multicolumn{2}{|c|}{ yes } & \multicolumn{2}{|c|}{ yes } & \multicolumn{2}{|c|}{ yes } \\
\hline SSC terms & \multicolumn{2}{|c|}{ yes } & \multicolumn{2}{|c|}{ yes } & \multicolumn{2}{|c|}{ yes } & \multicolumn{2}{|c|}{ yes } \\
\hline Number of observations & \multicolumn{2}{|c|}{4802} & \multicolumn{2}{|c|}{2808} & \multicolumn{2}{|c|}{2845} & \multicolumn{2}{|c|}{3847} \\
\hline Number of individuals & \multicolumn{2}{|c|}{1748} & \multicolumn{2}{|c|}{1023} & \multicolumn{2}{|c|}{1042} & \multicolumn{2}{|c|}{1389} \\
\hline Overall F-test & \multicolumn{2}{|c|}{$\mathrm{F}(15,1335)=42.00$} & \multicolumn{2}{|c|}{$F(15,590)=14.39$} & \multicolumn{2}{|c|}{$\mathrm{F}(15,609)=15.65$} & \multicolumn{2}{|c|}{$F(15,956)=25.87$} \\
\hline F-test SSC terms & \multicolumn{2}{|c|}{$\mathrm{F}(4,1335)=24.82$} & \multicolumn{2}{|c|}{$F(4,590)=13.57$} & \multicolumn{2}{|c|}{$F(4,609)=14.67$} & \multicolumn{2}{|c|}{$F(4,956)=18.29$} \\
\hline$p$-value & \multicolumn{2}{|c|}{0.000} & \multicolumn{2}{|c|}{0.000} & \multicolumn{2}{|c|}{0.000} & \multicolumn{2}{|c|}{0.000} \\
\hline R-squared & \multicolumn{2}{|c|}{0.2881} & \multicolumn{2}{|c|}{0.2274} & 0.2 & & 0.2 & \\
\hline $\operatorname{corr}\left(\eta_{i}, X_{i t} \alpha\right)$ & & & & & -0.3 & & -0.3 & \\
\hline
\end{tabular}

${ }^{*} p<0.10,{ }^{* *} p<0.05$, *** $p<0.01$.

SSC stands for sample selection correction.

[G1]: Control group (992 individuals).

[G2]: Dropout group with only classroom training and no internship placement (183 individuals).

[G3]: Dropout group with classroom training and internship placement (231 individuals).

[G4]: Treatment group with the full treatment (578 individuals).

The time dimension of the panel consists of four time periods: Nov-99, May-01, Nov-01, and May-02. This represents baseline before Projoven, 6 months after Projoven, 12 months after Projoven, and 18 months after Projoven, respectively. In all the models, the base periods are Nov99 and May-01. Two base periods are chosen, as the treatment variable takes the value zero for all individuals (treatment and controls) before the programme (Nov-99).

Clustered robust standard errors. The standard errors should be interpreted as asymptotic lower bounds. 
Table A14.

FE estimates [with sample selection correction - Wooldridge, 1995] Projoven sixth Public Call internship placement effects on monthly wages. Heterogeneous treatment over time [only trainees sample].

\begin{tabular}{|c|c|c|c|c|}
\hline & \multicolumn{2}{|c|}{ [G3] vs. [G2] } & \multicolumn{2}{|c|}{ [G4] vs. [G2] } \\
\hline & Coef. & $\begin{array}{l}\text { Std. } \\
\text { err. }\end{array}$ & Coef. & $\begin{array}{l}\text { Std. } \\
\text { err. }\end{array}$ \\
\hline Internship & 0.087 & $(0.143)$ & 0.109 & $(0.124)$ \\
\hline Internship [12 months] & 0.073 & $(0.109)$ & $-0.163^{*}$ & $(0.088)$ \\
\hline Internship [18 months] & -0.017 & $(0.109)$ & $-0.268^{* * *}$ & $(0.090)$ \\
\hline Years schooling & $0.515^{* * *}$ & $(0.141)$ & $0.453^{* * *}$ & $(0.131)$ \\
\hline Potential experience & $0.474^{* * *}$ & $(0.132)$ & $0.471^{* * *}$ & $(0.125)$ \\
\hline Previous job-training course & -0.112 & $(0.073)$ & $-0.128^{* *}$ & $(0.052)$ \\
\hline Commerce sector & $-0.163^{* *}$ & $(0.078)$ & $-0.134^{* *}$ & $(0.066)$ \\
\hline Manufacturing sector & -0.108 & $(0.082)$ & 0.007 & $(0.059)$ \\
\hline Micro enterprise & $-0.272^{* * *}$ & $(0.065)$ & $-0.401^{* * *}$ & $(0.049)$ \\
\hline Constant & -2.043 & $(1.907)$ & -1.288 & $(1.803)$ \\
\hline Time Dummies & \multicolumn{2}{|c|}{ Yes } & \multicolumn{2}{|c|}{ yes } \\
\hline SSC terms & \multicolumn{2}{|c|}{ Yes } & \multicolumn{2}{|c|}{ yes } \\
\hline Number of observations & \multicolumn{2}{|c|}{955} & \multicolumn{2}{|c|}{1957} \\
\hline Number of individuals & \multicolumn{2}{|c|}{359} & \multicolumn{2}{|c|}{706} \\
\hline Overall F- test & \multicolumn{2}{|c|}{$F(15,358)=20.19$} & \multicolumn{2}{|c|}{$F(15,705)=30.09$} \\
\hline F-test SSC terms & \multicolumn{2}{|c|}{$F(4,358)=9.95$} & \multicolumn{2}{|c|}{$\mathrm{F}(4,705)=17.11$} \\
\hline$p$-value & \multicolumn{2}{|c|}{0.000} & \multicolumn{2}{|c|}{0.000} \\
\hline R-squared & \multicolumn{2}{|c|}{0.3838} & \multicolumn{2}{|c|}{0.370} \\
\hline $\operatorname{corr}\left(\eta_{i}, X_{i t} \alpha\right)$ & \multicolumn{2}{|c|}{-0.808} & \multicolumn{2}{|c|}{-0.7976} \\
\hline
\end{tabular}

${ }^{*} p<0.10,{ }^{* *} p<0.05,{ }^{* * *} p<0.01$.

SSC stands for sample selection correction.

[G2]: Dropout group with only classroom training and no internship placement (183 individuals).

[G3]: Dropout group with classroom training and internship placement (231 individuals).

[G4]: Treatment group with the full treatment (578 individuals).

The time dimension of the panel consists of four time periods: Nov-99, May-01, Nov-01, and May-02. This represents baseline before Projoven, 6 months after Projoven, 12 months after Projoven, and 18 months after Projoven, respectively. In all the models, the base periods are Nov99 and May-01. Two base periods are chosen, as the treatment variable takes the value zero for all individuals (treatment and controls) before the programme (Nov-99).

Robust standard errors adjusted for ECAPs clusters. The standard errors should be interpreted as asymptotic lower bounds. 
Table A15.

Pooled two-stage least squares with sample selection correction estimation of Projoven sixth Public Call internship placement effects. Endogenous and heterogeneous treatment over time [only trainees sample] [G3] vs. [G2].

\begin{tabular}{|c|c|c|c|c|c|c|}
\hline & \multicolumn{2}{|c|}{$\begin{array}{c}\text { Dep. var. ov. } \\
\text { employment [LPM] [1] }\end{array}$} & \multicolumn{2}{|c|}{$\begin{array}{c}\text { Dep. var. formal } \\
\text { employment [LPM] [2] }\end{array}$} & \multicolumn{2}{|c|}{$\begin{array}{c}\text { Dep. var. In monthly } \\
\text { wages [3] }\end{array}$} \\
\hline & Coef. & Std. err. & Coef. & Std. err. & Coef. & Std. err. \\
\hline Internship placement & 0.134 & $(0.401)$ & 0.632 & $(0.510)$ & -0.277 & $(0.764)$ \\
\hline Internship placement * [12 months] & 0.196 & $(0.423)$ & -0.104 & $(0.558)$ & 0.692 & $(0.790)$ \\
\hline Internship placement * [18 months] & 0.075 & $(0.408)$ & -0.264 & $(0.510)$ & -0.007 & $(0.746)$ \\
\hline Years schooling & -0.05 & $(0.213)$ & -0.281 & $(0.192)$ & $0.831^{* * *}$ & $(0.281)$ \\
\hline Potential experience & -0.086 & $(0.216)$ & -0.261 & $(0.198)$ & $0.785^{* * *}$ & $(0.290)$ \\
\hline Female & $-0.090^{* * *}$ & $(0.027)$ & 0.019 & $(0.032)$ & $-0.226^{\star * *}$ & $(0.054)$ \\
\hline Child & 0.125 & $(0.085)$ & & & & \\
\hline Child*Female & $-0.226^{* * *}$ & $(0.070)$ & & & & \\
\hline Married & $-0.212^{* * *}$ & $(0.072)$ & & & & \\
\hline Ln hh income per capita & -0.016 & $(0.010)$ & & & & \\
\hline Previous job-training course & $-0.113^{* * *}$ & $(0.041)$ & 0.015 & $(0.052)$ & -0.038 & $(0.077)$ \\
\hline Arequipa & $0.134^{\star * *}$ & $(0.031)$ & $0.375^{\star * *}$ & $(0.063)$ & $-0.559 * * *$ & $(0.102)$ \\
\hline Chiclayo & -0.02 & $(0.043)$ & $0.436^{* * *}$ & $(0.062)$ & $-0.172^{*}$ & $(0.103)$ \\
\hline Cusco & $0.211^{*}$ & $(0.110)$ & $0.263^{* * *}$ & $(0.090)$ & 0.017 & $(0.156)$ \\
\hline Trujillo & -0.066 & $(0.075)$ & $0.263^{* * *}$ & $(0.090)$ & $-0.328^{* *}$ & $(0.138)$ \\
\hline Commerce sector & & & 0.050 & $(0.038)$ & -0.068 & $(0.062)$ \\
\hline Manufacturing sector & & & 0.035 & $(0.038)$ & 0.02 & $(0.061)$ \\
\hline Micro enterprise & & & $-0.127^{* * *}$ & $(0.036)$ & $-0.438^{* * *}$ & $(0.057)$ \\
\hline Constant & $0.580^{*}$ & $(0.342)$ & -0.252 & $(0.304$ & $6.177^{* * *}$ & $(0.477)$ \\
\hline Mundlak terms & \multicolumn{2}{|c|}{ yes } & \multicolumn{2}{|c|}{ yes } & \multicolumn{2}{|c|}{ yes } \\
\hline Time Dummies & \multicolumn{2}{|c|}{ yes } & \multicolumn{2}{|c|}{ yes } & \multicolumn{2}{|c|}{ yes } \\
\hline SSC terms & \multicolumn{2}{|c|}{ no } & \multicolumn{2}{|c|}{ yes } & \multicolumn{2}{|c|}{ yes } \\
\hline Number of observations & \multicolumn{2}{|c|}{1653} & \multicolumn{2}{|c|}{1048} & \multicolumn{2}{|c|}{985} \\
\hline Overall F- test & \multicolumn{2}{|c|}{$F(23,1629)=13.09$} & \multicolumn{2}{|c|}{$\mathrm{F}(26,1021)=12.11$} & \multicolumn{2}{|c|}{$F(26,958)=23.16$} \\
\hline Wald Test SSC terms & \multicolumn{2}{|c|}{ n. a. } & \multicolumn{2}{|c|}{$\chi_{(4)}^{2}=6.46$} & \multicolumn{2}{|c|}{$\chi_{(4)}^{2}=4.07$} \\
\hline$p$-value & \multicolumn{2}{|c|}{ n. a. } & \multicolumn{2}{|c|}{0.1671} & \multicolumn{2}{|c|}{0.3971} \\
\hline Sargan test & \multicolumn{2}{|c|}{$\chi_{(3)}^{2}=3.840$} & \multicolumn{2}{|c|}{$\chi_{(3)}^{2}=4.664$} & \multicolumn{2}{|c|}{$\chi_{(3)}^{2}=6.829$} \\
\hline$p$-value & \multicolumn{2}{|c|}{0.2792} & \multicolumn{2}{|c|}{0.1981} & \multicolumn{2}{|c|}{0.0776} \\
\hline
\end{tabular}

${ }^{*} p<0.10,{ }^{* *} p<0.05,{ }^{* * *} p<0.01$

SSC stands for sample selection correction.

[G2]: Dropout group with only classroom training and no internship placement (183 individuals). [G3]: Dropout group with classroom training and internship placement (231 individuals).

The time dimension of the panel consists of four time periods: Nov-99, May-01, Nov-01, and May-02. This represents baseline before Projoven, 6 months after Projoven, 12 months after Projoven, and 18 months after Projoven, respectively. In all the models, the base periods are Nov99 and May-01. Two base periods are chosen, as the treatment variable takes the value zero for all individuals (treatment and controls) before the programme (Nov-99).

Robust standard errors adjusted for ECAPs clusters. The standard errors should be interpreted as asymptotic lower bounds. 
Table A16.

Pooled two-stage least squares with sample selection correction estimation of Projoven sixth Public Call internship placement effects. Endogenous and heterogeneous treatment over time [only trainees sample] [G4] vs. [G2].

\begin{tabular}{|c|c|c|c|c|c|c|}
\hline & \multicolumn{2}{|c|}{$\begin{array}{c}\text { Dep. var. ov. } \\
\text { employment [LPM] [1] }\end{array}$} & \multicolumn{2}{|c|}{$\begin{array}{c}\text { Dep. var. formal } \\
\text { employment [LPM] [2] }\end{array}$} & \multicolumn{2}{|c|}{$\begin{array}{c}\text { Dep. var. In monthly } \\
\text { wages [3] }\end{array}$} \\
\hline & Coef. & Std. err. & Coef. & Std. err. & Coef. & Std. err. \\
\hline Internship placement & 0.255 & $(0.184)$ & 0.747 & $(0.781)$ & 0.652 & $(1.109)$ \\
\hline Internship placement * [12 months] & -0.115 & $(0.201)$ & 0.039 & $(0.752)$ & 0.502 & $(1.067)$ \\
\hline Internship placement * [18 months] & -0.137 & $(0.195)$ & -0.388 & $(0.745)$ & -0.271 & $(1.053)$ \\
\hline Years schooling & -0.124 & $(0.139)$ & -0.22 & $(0.278)$ & 0.388 & $(0.385)$ \\
\hline Potential experience & -0.139 & $(0.140)$ & -0.223 & $(0.288)$ & 0.371 & $(0.400)$ \\
\hline Female & $-0.097^{* * *}$ & $(0.019)$ & 0.02 & $(0.034)$ & $-0.141^{* *}$ & $(0.055)$ \\
\hline Child & 0.087 & $(0.058)$ & & & & \\
\hline Child*Female & $-0.231^{* * *}$ & $(0.044)$ & & & & \\
\hline Married & $-0.133^{* * *}$ & $(0.049)$ & & & & \\
\hline Ln hh income per capita & $-0.013^{* * *}$ & $(0.004)$ & & & & \\
\hline Previous job-training course & -0.037 & $(0.027)$ & 0.001 & $(0.041)$ & 0.018 & $(0.069)$ \\
\hline Arequipa & $0.107^{* * *}$ & $(0.023)$ & $0.325^{* * *}$ & $(0.059)$ & $-0.646^{* * *}$ & $(0.096)$ \\
\hline Chiclayo & -0.042 & $(0.042)$ & $0.346^{* * *}$ & $(0.059)$ & -0.042 & $(0.099)$ \\
\hline Cusco & $0.058^{* *}$ & $(0.025)$ & 0.038 & $(0.049)$ & -0.039 & $(0.070)$ \\
\hline Trujillo & $-0.099^{* * *}$ & $(0.024)$ & $0.106^{* * *}$ & $(0.037)$ & $-0.161^{* * *}$ & $(0.056)$ \\
\hline Commerce sector & a & & 0.032 & $(0.029)$ & -0.043 & $(0.050)$ \\
\hline Manufacturing sector & a & & 0.035 & $(0.029)$ & 0.043 & $(0.048)$ \\
\hline Micro enterprise & a & & $-0.126^{* * *}$ & $(0.023)$ & $-0.515^{\star * *}$ & $(0.040)$ \\
\hline Constant & $0.558^{* * *}$ & $(0.201)$ & -0.232 & $(0.406)$ & $5.783^{* * *}$ & $(0.574)$ \\
\hline Mundlak terms & \multicolumn{2}{|c|}{ yes } & \multicolumn{2}{|c|}{ yes } & \multicolumn{2}{|c|}{ yes } \\
\hline Time Dummies & \multicolumn{2}{|c|}{ yes } & \multicolumn{2}{|c|}{ yes } & \multicolumn{2}{|c|}{ yes } \\
\hline SSC terms & \multicolumn{2}{|c|}{ no } & \multicolumn{2}{|c|}{ yes } & \multicolumn{2}{|c|}{ yes } \\
\hline Number of observations & \multicolumn{2}{|c|}{3083} & \multicolumn{2}{|c|}{2097} & \multicolumn{2}{|c|}{2041} \\
\hline Overall F-test & \multicolumn{2}{|c|}{$\mathrm{F}(23,3059)=21.81$} & \multirow{2}{*}{\multicolumn{2}{|c|}{$\begin{array}{c}\mathrm{F}(26,2070)=20.89 \\
\chi_{(3)}^{2}=4.82\end{array}$}} & \multicolumn{2}{|c|}{$\mathrm{F}(26,2014)=37.08$} \\
\hline Wald Test SSC terms & \multicolumn{2}{|c|}{ n. a. } & & & \multicolumn{2}{|c|}{$\chi_{(3)}^{2}=7.63$} \\
\hline$p$-value & \multicolumn{2}{|c|}{ n. a. } & \multicolumn{2}{|c|}{0.3064} & \multicolumn{2}{|c|}{0.106} \\
\hline Sargan test & \multicolumn{2}{|c|}{$\chi_{(3)}^{2}=8.329$} & \multicolumn{2}{|c|}{$\chi_{(3)}^{2}=1.225$} & \multicolumn{2}{|c|}{$\chi_{(3)}^{2}=3.255$} \\
\hline$p$-value & \multicolumn{2}{|c|}{0.0397} & \multicolumn{2}{|c|}{0.7471} & \multicolumn{2}{|c|}{0.3539} \\
\hline
\end{tabular}

SSC stands for sample selection correction.

[G2]: Dropout group with only classroom training and no internship placement (183 individuals). [G4]: Treatment group with the full treatment (578 individuals).

The time dimension of the panel consists of four time periods: Nov-99, May-01, Nov-01, and May-02. This represents baseline before Projoven, 6 months after Projoven, 12 months after Projoven, and 18 months after Projoven, respectively. In all the models, the base periods are Nov99 and May-01. Two base periods are chosen, as the treatment variable takes the value zero for all individuals (treatment and controls) before the programme (Nov-99).

Robust standard errors adjusted for ECAPs clusters. The standard errors should be interpreted as asymptotic lower bounds. 
Table A17.

Pooled two-stage least squares with sample selection correction estimation of Projoven sixth Public Call internship completion effects. Heterogeneous treatment over time [only trainees placed in internships sample] [G4] vs. [G3].

\begin{tabular}{|c|c|c|c|c|c|c|}
\hline & \multicolumn{2}{|c|}{$\begin{array}{c}\text { Dep. var. ov. } \\
\text { employment [LPM] [1] }\end{array}$} & \multicolumn{2}{|c|}{$\begin{array}{c}\text { Dep. var. formal } \\
\text { employment [LPM] [2] }\end{array}$} & \multicolumn{2}{|c|}{$\begin{array}{c}\text { Dep. var. In monthly } \\
\text { wages [3] }\end{array}$} \\
\hline & Coef. & $\begin{array}{l}\text { Std. } \\
\text { err. }\end{array}$ & Coef. & $\begin{array}{l}\text { Std. } \\
\text { err. }\end{array}$ & Coef. & $\begin{array}{l}\text { Std. } \\
\text { err. }\end{array}$ \\
\hline Internship Completion & $0.245^{*}$ & $(0.130)$ & $0.442^{* * *}$ & $(0.166)$ & $1.051^{*}$ & $(0.625)$ \\
\hline Internship Completion * [12 months] & -0.131 & $(0.143)$ & -0.009 & $(0.152)$ & -0.714 & $(0.508)$ \\
\hline Internship Completion * [18 months] & 0.010 & $(0.134)$ & -0.292 & $(0.255)$ & -0.622 & $(0.605)$ \\
\hline Years schooling & -0.158 & $(0.126)$ & -0.187 & $(0.192)$ & -0.348 & $(0.603)$ \\
\hline Potential experience & -0.151 & $(0.121)$ & -0.19 & $(0.176)$ & -0.357 & $(0.581)$ \\
\hline Female & $-0.097^{* * *}$ & $(0.021)$ & -0.026 & $(0.022)$ & $-0.188^{* * *}$ & $(0.067)$ \\
\hline Child & -0.013 & $(0.051)$ & & & & \\
\hline Child*Female & $-0.238^{* * *}$ & $(0.045)$ & & & & \\
\hline Married & -0.087 & $(0.056)$ & & & & \\
\hline Ln hh income per capita & $-0.016^{* * *}$ & $(0.004)$ & & & & \\
\hline Previous job-training course & -0.051 & $(0.033)$ & -0.034 & $(0.032)$ & -0.058 & $(0.058)$ \\
\hline Arequipa & $0.092^{* * *}$ & $(0.029)$ & $0.370^{* * *}$ & $(0.039)$ & $-0.637^{* * *}$ & $(0.120)$ \\
\hline Chiclayo & -0.041 & $(0.040)$ & $0.362^{* * *}$ & $(0.044)$ & -0.07 & $(0.090)$ \\
\hline Cusco & 0.019 & $(0.032)$ & 0.037 & $(0.059)$ & -0.135 & $(0.093)$ \\
\hline Trujillo & $-0.112^{* * *}$ & $(0.041)$ & 0.053 & $(0.045)$ & $-0.233^{* *}$ & $(0.105)$ \\
\hline Commerce sector & a & & 0.01 & $(0.033)$ & -0.007 & $(0.067)$ \\
\hline Manufacturing sector & a & & 0.011 & $(0.037)$ & 0.058 & $(0.058)$ \\
\hline Micro enterprise & a & & $-0.152^{* * *}$ & $(0.028)$ & $-0.548^{* * *}$ & $(0.053)$ \\
\hline Constant & $0.606^{* * *}$ & $(0.163)$ & 0.053 & $(0.288)$ & $5.416^{* * *}$ & $(0.687)$ \\
\hline Mundlak terms & \multicolumn{2}{|c|}{ yes } & \multicolumn{2}{|c|}{ yes } & \multicolumn{2}{|c|}{ yes } \\
\hline Time Dummies & \multicolumn{2}{|c|}{ yes } & \multicolumn{2}{|c|}{ yes } & \multicolumn{2}{|c|}{ yes } \\
\hline SSC terms & \multicolumn{2}{|c|}{ no } & \multicolumn{2}{|c|}{ yes } & \multicolumn{2}{|c|}{ yes } \\
\hline Number of observations & \multicolumn{2}{|c|}{1489} & \multicolumn{2}{|c|}{914} & \multicolumn{2}{|c|}{815} \\
\hline Overall F-test & \multicolumn{2}{|c|}{$F(23,38)=129.80$} & \multicolumn{2}{|c|}{$F(26,38)=113.26$} & \multicolumn{2}{|c|}{$F(26,38)=89.19$} \\
\hline Wald Test SSC terms & \multicolumn{2}{|c|}{ n. a. } & \multicolumn{2}{|c|}{$\chi_{(4)}^{2}=6.96$} & \multicolumn{2}{|c|}{$\chi_{(4)}^{2}=14.37$} \\
\hline$p$-value & \multicolumn{2}{|c|}{ n. a. } & \multicolumn{2}{|c|}{0.138} & \multicolumn{2}{|c|}{0.0062} \\
\hline
\end{tabular}

${ }^{*} p<0.10,{ }^{* *} p<0.05$, *** $p<0.01$.

SSC stands for sample selection correction.

[G3]: Dropout group with classroom training and internship placement (231 individuals).

[G4]: Treatment group with the full treatment (578 individuals).

The time dimension of the panel consists of four time periods: Nov-99, May-01, Nov-01, and May-02. This represents baseline before Projoven, 6 months after Projoven, 12 months after Projoven, and 18 months after Projoven, respectively. In all the models, the base periods are Nov99 and May-01. Two base periods are chosen, as the treatment variable takes the value zero for all individuals (treatment and controls) before the programme (Nov-99).

Robust standard errors adjusted for ECAPs clusters. The standard errors should be interpreted as asymptotic lower bounds. 
Table A18.

LPM-RE estimates Projoven sixth Public Call participation effects on overall employment. Heterogeneous effects over time and across individual characteristics.

\begin{tabular}{|c|c|c|c|c|c|c|}
\hline & \multicolumn{2}{|c|}{ [G2] vs. [G1] } & \multicolumn{2}{|c|}{ [G3] vs. [G1] } & \multicolumn{2}{|c|}{ [G4] vs. [G1] } \\
\hline & Coef. & Std. err. & Coef. & Std. err. & Coef. & Std. err. \\
\hline Projoven*Female & -0.079 & $(0.067)$ & $-0.114^{*}$ & $(0.065)$ & $-0.069^{*}$ & $(0.039)$ \\
\hline Projoven*No work experience & $0.167^{* *}$ & $(0.068)$ & $0.148^{* *}$ & $(0.068)$ & $0.243^{* * *}$ & $(0.048)$ \\
\hline Projoven*Lowest quartile & -0.013 & $(0.077)$ & 0.012 & $(0.071)$ & 0.029 & $(0.052)$ \\
\hline Projoven*Female ${ }^{*}[12$ months $]$ & 0.084 & $(0.073)$ & 0.100 & $(0.067)$ & -0.013 & $(0.041)$ \\
\hline Projoven*No work experience*[12 months] & -0.01 & $(0.079)$ & -0.074 & $(0.068)$ & -0.043 & $(0.047)$ \\
\hline Projoven*Lowest quartile*[12 months $]$ & -0.052 & $(0.083)$ & -0.026 & $(0.068)$ & 0.023 & $(0.052)$ \\
\hline Projoven*Female*[18 months] & 0.011 & $(0.077)$ & 0.084 & $(0.070)$ & 0.000 & $(0.046)$ \\
\hline Projoven*No work experience*[18 months] & 0.003 & $(0.082)$ & 0.085 & $(0.076)$ & $0.093^{*}$ & $(0.050)$ \\
\hline Projoven*Lowest quartile*[18 months] & -0.01 & $(0.084)$ & -0.055 & $(0.080)$ & 0.007 & $(0.053)$ \\
\hline Female & $-0.050^{*}$ & $(0.029)$ & $-0.048^{*}$ & $(0.028)$ & $-0.046^{*}$ & $(0.026)$ \\
\hline No work experience & $-0.373^{* * *}$ & $(0.030)$ & $-0.374^{* * *}$ & $(0.030)$ & $-0.391^{* * *}$ & $(0.027)$ \\
\hline Lowest quartile & $-0.064^{*}$ & $(0.033)$ & $-0.055^{*}$ & $(0.033)$ & $-0.055^{*}$ & $(0.031)$ \\
\hline Constant & $0.181^{* * *}$ & $(0.021)$ & $0.177^{* * *}$ & $(0.021)$ & $0.165^{* * *}$ & $(0.017)$ \\
\hline Time Dummies & \multicolumn{2}{|c|}{ Yes } & \multicolumn{2}{|c|}{ yes } & \multicolumn{2}{|c|}{ yes } \\
\hline Number of observations & \multicolumn{2}{|c|}{2571} & \multicolumn{2}{|c|}{2626} & \multicolumn{2}{|c|}{3434} \\
\hline Number of individuals & \multicolumn{2}{|c|}{645} & \multicolumn{2}{|c|}{659} & \multicolumn{2}{|c|}{861} \\
\hline Wald test & \multicolumn{2}{|c|}{$\chi_{(14)}^{2}=263.51$} & \multicolumn{2}{|c|}{$\chi_{(14)}^{2}=268.74$} & \multicolumn{2}{|c|}{$\chi_{(14)}^{2}=345.39$} \\
\hline R-squared & \multicolumn{2}{|c|}{0.3307} & \multicolumn{2}{|c|}{0.323} & \multicolumn{2}{|c|}{0.2901} \\
\hline
\end{tabular}

${ }^{*} p<0.10,{ }^{* *} p<0.05, * * * p<0.01$.

[G1]: Control group (992 individuals).

[G2]: Dropout group with only classroom training and no internship placement (183 individuals).

[G3]: Dropout group with classroom training and internship placement (231 individuals).

[G4]: Treatment group with the full treatment (578 individuals).

The time dimension of the panel consists of four time periods: Nov-99, May-01, Nov-01, and May-02. This represents baseline before Projoven, 6 months after Projoven, 12 months after Projoven, and 18 months after Projoven, respectively. In all the models the base periods are Nov99 and May-01. Two base periods are chosen, as the treatment variable takes the value zero for all individuals (treatment and controls) before the programme (Nov-99).

Clustered robust standard errors. 
Table A19.

LPM-RE estimates Projoven sixth Public Call internship placement effects on overall employment. Heterogeneous effects over time and across individual characteristics [only trainees sample].

\begin{tabular}{|c|c|c|c|c|}
\hline & \multicolumn{2}{|c|}{ [G3] vs. [G2] } & \multicolumn{2}{|c|}{ [G4] vs. [G2] } \\
\hline & Coef. & Std. err. & Coef. & Std. err. \\
\hline Internship*Female & -0.095 & $(0.065)$ & -0.049 & $(0.039)$ \\
\hline Internship*No work experience & 0.108 & $(0.068)$ & $0.241^{* * *}$ & $(0.048)$ \\
\hline Internship*Lowest quartile & 0.009 & $(0.069)$ & 0.014 & $(0.051)$ \\
\hline Internship ${ }^{*}$ Female ${ }^{*}[12$ months $]$ & 0.102 & $(0.067)$ & 0.000 & $(0.042)$ \\
\hline Internship*No work experience*[12 months] & -0.067 & $(0.069)$ & -0.038 & $(0.048)$ \\
\hline Internship*Lowest quartile*[12 months] & -0.020 & $(0.068)$ & 0.027 & $(0.052)$ \\
\hline Internship*Female*[18 months] & 0.106 & $(0.070)$ & 0.041 & $(0.045)$ \\
\hline Internship*No work experience*[18 months] & 0.105 & $(0.076)$ & $0.106^{* *}$ & $(0.050)$ \\
\hline Internship*Lowest quartile*[18 months] & -0.032 & $(0.079)$ & 0.018 & $(0.053)$ \\
\hline Female & -0.036 & $(0.032)$ & $-0.045^{*}$ & $(0.025)$ \\
\hline No work experience & $-0.315^{* * *}$ & $(0.034)$ & $-0.360^{* * *}$ & $(0.028)$ \\
\hline Lowest quartile & -0.029 & $(0.035)$ & -0.047 & $(0.029)$ \\
\hline Constant & $0.164^{* * *}$ & $(0.024)$ & $0.145^{* * *}$ & $(0.017)$ \\
\hline Time Dummies & \multicolumn{2}{|c|}{ yes } & \multicolumn{2}{|c|}{ yes } \\
\hline Number of observations & \multicolumn{2}{|c|}{821} & \multicolumn{2}{|c|}{1629} \\
\hline Number of individuals & \multicolumn{2}{|c|}{206} & \multicolumn{2}{|c|}{408} \\
\hline Wald test & \multicolumn{2}{|c|}{$\chi_{(14)}^{2}=118.23$} & \multicolumn{2}{|c|}{$\chi_{(14)}^{2}=221.66$} \\
\hline R-squared & \multicolumn{2}{|c|}{0.2024} & \multicolumn{2}{|c|}{0.1729} \\
\hline
\end{tabular}

${ }^{*} p<0.10,{ }^{* *} p<0.05,{ }^{* * *} p<0.01$.

[G2]: Dropout group with only classroom training and no internship placement (183 individuals).

[G3]: Dropout group with classroom training and internship placement (231 individuals).

[G4]: Treatment group with the full treatment (578 individuals).

The time dimension of the panel consists of four time periods: Nov-99, May-01, Nov-01, and May-02. This represents baseline before Projoven, 6 months after Projoven, 12 months after Projoven, and 18 months after Projoven, respectively. In all the models, the base periods are Nov99 and May-01. Two base periods are chosen, as the treatment variable takes the value zero for all individuals (treatment and controls) before the programme (Nov-99).

Robust standard errors adjusted for ECAPs clusters. 
Table A20.

LPM-RE estimates [with sample selection correction - Wooldridge, 1995] Projoven sixth Public Call participation effects on formal employment. Heterogeneous effects over time and across individual characteristics.

\begin{tabular}{|c|c|c|c|c|c|c|}
\hline & \multicolumn{2}{|c|}{ [G2] vs. [G1] } & \multicolumn{2}{|c|}{ [G3] vs. [G1] } & \multicolumn{2}{|c|}{ [G4] vs. [G1] } \\
\hline & Coef. & Std. err. & Coef. & Std. err. & Coef. & Std. err. \\
\hline Projoven*Female & -0.105 & $(0.086)$ & -0.099 & $(0.087)$ & -0.059 & $(0.047)$ \\
\hline Projoven*No work experience & 0.021 & $(0.097)$ & -0.062 & $(0.098)$ & 0.094 & $(0.065)$ \\
\hline Projoven*Lowest quartile & 0.031 & $(0.103)$ & $0.159^{*}$ & $(0.088)$ & -0.042 & $(0.065)$ \\
\hline Projoven*Female ${ }^{*}[12$ months $]$ & 0.008 & $(0.102)$ & 0.111 & $(0.097)$ & 0.024 & $(0.052)$ \\
\hline Projoven*No work experience ${ }^{*}[12$ months] & -0.090 & $(0.107)$ & $-0.190^{*}$ & $(0.099)$ & -0.091 & $(0.063)$ \\
\hline Projoven*Lowest quartile*[12 months] & 0.003 & $(0.108)$ & -0.022 & $(0.102)$ & 0.059 & $(0.063)$ \\
\hline Projoven*Female*[18 months] & 0.046 & $(0.098)$ & 0.068 & $(0.086)$ & -0.011 & $(0.052)$ \\
\hline Projoven*No work experience ${ }^{*}[18$ months] & 0.089 & $(0.102)$ & 0.034 & $(0.095)$ & -0.064 & $(0.063)$ \\
\hline Projoven*Lowest quartile*[18 months] & 0.003 & $(0.106)$ & -0.08 & $(0.078)$ & 0.02 & $(0.066)$ \\
\hline Female & $0.108^{* * *}$ & $(0.040)$ & $0.091^{* *}$ & $(0.040)$ & $0.114^{* * *}$ & $(0.035)$ \\
\hline No work experience & 0.069 & $(0.046)$ & 0.047 & $(0.044)$ & 0.048 & $(0.042)$ \\
\hline Lowest quartile & $0.105^{* *}$ & $(0.042)$ & $0.072^{*}$ & $(0.041)$ & $0.085^{* *}$ & $(0.038)$ \\
\hline Constant & $-0.094^{* * *}$ & $(0.033)$ & $-0.064^{* *}$ & $(0.032)$ & $-0.086^{* * *}$ & $(0.025)$ \\
\hline Time Dummies & \multicolumn{2}{|c|}{ yes } & \multicolumn{2}{|c|}{ yes } & \multicolumn{2}{|c|}{ yes } \\
\hline Number of observations & \multicolumn{2}{|c|}{1538} & \multicolumn{2}{|c|}{1559} & \multicolumn{2}{|c|}{2110} \\
\hline Number of individuals & \multicolumn{2}{|c|}{614} & \multicolumn{2}{|c|}{633} & \multicolumn{2}{|c|}{828} \\
\hline Overall Wald test & \multicolumn{2}{|c|}{$\chi_{(14)}^{2}=37.86$} & \multicolumn{2}{|c|}{$\chi_{(14)}^{2}=34.22$} & \multicolumn{2}{|c|}{$\chi_{(14)}^{2}=40.54$} \\
\hline R-squared & \multicolumn{2}{|c|}{0.0644} & \multicolumn{2}{|c|}{0.0479} & \multicolumn{2}{|c|}{0.0495} \\
\hline
\end{tabular}

${ }^{*} p<0.10,{ }^{* *} p<0.05,{ }^{* * *} p<0.01$.

[G1]: Control group (992 individuals).

[G2]: Dropout group with only classroom training and no internship placement (183 individuals).

[G3]: Dropout group with classroom training and internship placement (231 individuals).

[G4]: Treatment group with the full treatment (578 individuals).

The time dimension of the panel consists of four time periods: Nov-99, May-01, Nov-01, and May-02. This represents baseline before Projoven, 6 months after Projoven, 12 months after Projoven, and 18 months after Projoven, respectively. In all the models the base periods are Nov99 and May-01. Two base periods are chosen, as the treatment variable takes the value zero for all individuals (treatment and controls) before the programme (Nov-99).

Clustered robust standard errors. 
Table A21.

RE estimates [with sample selection correction - Wooldridge, 1995] Projoven sixth Public Call participation effects on monthly wages. Heterogeneous effects over time and across individual characteristics.

\begin{tabular}{|c|c|c|c|c|c|c|}
\hline & \multicolumn{2}{|c|}{ [G2] vs. [G1] } & \multicolumn{2}{|c|}{ [G3] vs. [G1] } & \multicolumn{2}{|c|}{ [G4] vs. [G1] } \\
\hline & Coef. & Std. err. & Coef. & Std. err. & Coef. & Std. err. \\
\hline Projoven*Female & -0.151 & $(0.182)$ & 0.000 & $(0.152)$ & -0.108 & $(0.092)$ \\
\hline Projoven*No work experience & -0.241 & $(0.166)$ & -0.209 & $(0.177)$ & 0.193 & $(0.126)$ \\
\hline Projoven*Lowest quartile & $0.363^{*}$ & $(0.208)$ & 0.040 & $(0.187)$ & $0.215^{*}$ & $(0.117)$ \\
\hline Projoven*Female*[12 months $]$ & -0.115 & $(0.147)$ & $-0.221^{*}$ & $(0.122)$ & -0.061 & $(0.066)$ \\
\hline Projoven*No work experience*[12 months] & -0.03 & $(0.134)$ & $0.228^{*}$ & $(0.137)$ & -0.023 & $(0.080)$ \\
\hline Projoven*Lowest quartile*[12 months $]$ & 0.142 & $(0.161)$ & 0.089 & $(0.126)$ & 0.074 & $(0.085)$ \\
\hline Projoven ${ }^{*}$ Female ${ }^{*}[18$ months $]$ & -0.146 & $(0.155)$ & -0.168 & $(0.123)$ & 0.085 & $(0.067)$ \\
\hline Projoven*No work experience*[18 months] & $0.312^{* *}$ & $(0.138)$ & 0.211 & $(0.168)$ & -0.001 & $(0.080)$ \\
\hline Projoven*Lowest quartile*[18 months $]$ & -0.054 & $(0.155)$ & 0.061 & $(0.172)$ & -0.047 & $(0.084)$ \\
\hline Female & $-0.262^{* *}$ & $(0.125)$ & $-0.261^{* *}$ & $(0.125)$ & $-0.190^{*}$ & $(0.106)$ \\
\hline No work experience & $0.352^{* * *}$ & $(0.131)$ & $0.303^{* *}$ & $(0.131)$ & $0.245^{\star *}$ & $(0.118)$ \\
\hline Lowest quartile & 0.095 & $(0.131)$ & 0.132 & $(0.130)$ & -0.041 & $(0.116)$ \\
\hline Constant & 0.050 & $(0.078)$ & 0.061 & $(0.077)$ & 0.057 & $(0.061)$ \\
\hline Time Dummies & \multicolumn{2}{|c|}{ yes } & \multicolumn{2}{|c|}{ yes } & \multicolumn{2}{|c|}{ yes } \\
\hline Number of observations & \multicolumn{2}{|c|}{1303} & \multicolumn{2}{|c|}{1298} & \multicolumn{2}{|c|}{1814} \\
\hline Number of individuals & \multicolumn{2}{|c|}{528} & \multicolumn{2}{|c|}{536} & \multicolumn{2}{|c|}{732} \\
\hline Overall Wald test & \multicolumn{2}{|c|}{$\chi_{(14)}^{2}=40.78$} & \multicolumn{2}{|c|}{$\chi_{(14)}^{2}=20.25$} & \multicolumn{2}{|c|}{$\chi_{(14)}^{2}=35.99$} \\
\hline R-squared & \multicolumn{2}{|c|}{0.0366} & \multicolumn{2}{|c|}{0.0336} & \multicolumn{2}{|c|}{0.0141} \\
\hline
\end{tabular}

${ }^{*} p<0.10,{ }^{* *} p<0.05,{ }^{* * *} p<0.01$.

[G1]: Control group (992 individuals).

[G2]: Dropout group with only classroom training and no internship placement (183 individuals).

[G3]: Dropout group with classroom training and internship placement (231 individuals).

[G4]: Treatment group with the full treatment (578 individuals).

The time dimension of the panel consists of four time periods: Nov-99, May-01, Nov-01, and May-02. This represents baseline before Projoven, 6 months after Projoven, 12 months after Projoven, and 18 months after Projoven, respectively. In all the models, the base periods are Nov99 and May-01. Two base periods are chosen, as the treatment variable takes the value zero for all individuals (treatment and controls) before the programme (Nov-99).

Clustered robust standard errors. 
Table A22.

LPM-RE estimates [with sample selection correction - Wooldridge, 1995] Projoven sixth Public Call internship effects on formal employment. Heterogeneous effects over time and across individual characteristics [only trainees sample].

\begin{tabular}{|c|c|c|c|c|}
\hline & \multicolumn{2}{|c|}{ [G3] vs. [G2] } & \multicolumn{2}{|c|}{ [G4] vs. [G2] } \\
\hline & Coef. & Std. err. & Coef. & Std. err. \\
\hline Internship*Female & -0.084 & $(0.091)$ & -0.058 & $(0.049)$ \\
\hline Internship*No work experience & -0.059 & $(0.102)$ & $0.118^{*}$ & $(0.067)$ \\
\hline Internship*Lowest quartile & 0.128 & $(0.097)$ & -0.058 & $(0.071)$ \\
\hline Internship ${ }^{*}$ Female ${ }^{*}[12$ months $]$ & 0.104 & $(0.095)$ & 0.009 & $(0.053)$ \\
\hline Internship*No work experience*[12 months] & -0.153 & $(0.101)$ & -0.099 & $(0.063)$ \\
\hline Internship*Lowest quartile*[12 months] & -0.064 & $(0.103)$ & 0.053 & $(0.065)$ \\
\hline Internship*Female*[18 months] & 0.049 & $(0.088)$ & -0.026 & $(0.052)$ \\
\hline Internship*No work experience*[18 months] & 0.025 & $(0.097)$ & -0.071 & $(0.062)$ \\
\hline Internship*Lowest quartile*[18 months] & -0.126 & $(0.080)$ & -0.007 & $(0.067)$ \\
\hline Female & -0.006 & $(0.045)$ & $0.084^{* *}$ & $(0.037)$ \\
\hline No work experience & 0.032 & $(0.049)$ & 0.032 & $(0.046)$ \\
\hline Lowest quartile & $0.101^{* *}$ & $(0.049)$ & $0.099^{* *}$ & $(0.045)$ \\
\hline Constant & -0.021 & $(0.034)$ & $-0.068^{* * *}$ & $(0.024)$ \\
\hline Time Dummies & \multicolumn{2}{|c|}{ yes } & \multicolumn{2}{|c|}{ yes } \\
\hline Number of observations & \multicolumn{2}{|c|}{465} & \multicolumn{2}{|c|}{1016} \\
\hline Number of individuals & \multicolumn{2}{|c|}{187} & \multicolumn{2}{|c|}{382} \\
\hline Overall Wald test & \multicolumn{2}{|c|}{$\chi_{(14)}^{2}=21.76$} & \multicolumn{2}{|c|}{$\chi_{(14)}^{2}=29.58$} \\
\hline R-squared & \multicolumn{2}{|c|}{0.0317} & \multicolumn{2}{|c|}{0.0286} \\
\hline
\end{tabular}

${ }^{*} p<0.10,{ }^{* *} p<0.05, * * * p<0.01$.

[G2]: Dropout group with only classroom training and no internship placement (183 individuals).

[G3]: Dropout group with classroom training and internship placement (231 individuals).

[G4]: Treatment group with the full treatment (578 individuals).

The time dimension of the panel consists of four time periods: Nov-99, May-01, Nov-01, and May-02. This represents baseline before Projoven, 6 months after Projoven, 12 months after Projoven, and 18 months after Projoven, respectively. In all the models, the base periods are Nov99 and May-01. Two base periods are chosen, as the treatment variable takes the value zero for all individuals (treatment and controls) before the programme (Nov-99).

Robust standard errors adjusted for ECAPs clusters. 
Table A23.

RE estimates [with sample selection correction - Wooldridge, 1995] Projoven sixth Public Call internship placement effects on monthly wages. Heterogeneous treatment over time and across individual characteristics [only trainees sample].

\begin{tabular}{|c|c|c|c|c|}
\hline & \multicolumn{2}{|c|}{ [G3] vs. [G2] } & \multicolumn{2}{|c|}{ [G4] vs. [G2] } \\
\hline & Coef. & Std. err. & Coef. & Std. err. \\
\hline Internship*Female & 0.010 & $(0.158)$ & -0.124 & $(0.100)$ \\
\hline Internship* No work experience & -0.110 & $(0.198)$ & $0.353^{* * *}$ & (0.133) \\
\hline Internship*Lowest quartile & 0.193 & $(0.203)$ & $0.482^{* * *}$ & $(0.126)$ \\
\hline Internship ${ }^{*}$ Female $^{*}[12$ months $]$ & -0.189 & $(0.124)$ & -0.006 & $(0.067)$ \\
\hline Internship*No work experience ${ }^{*}[12$ months] & $0.268^{*}$ & $(0.141)$ & -0.002 & $(0.082)$ \\
\hline Internship*Lowest quartile*[12 months] & 0.033 & $(0.124)$ & 0.078 & (0.089) \\
\hline Internship*Female*[18 months] & -0.175 & $(0.127)$ & $0.140^{* *}$ & $(0.068)$ \\
\hline Internship*No work experience*[18 months] & 0.222 & $(0.180)$ & 0.042 & $(0.081)$ \\
\hline Internship*Lowest quartile*[18 months] & 0.020 & $(0.169)$ & -0.041 & $(0.089)$ \\
\hline Female & $-0.477^{* * *}$ & $(0.140)$ & $-0.239 * *$ & $(0.107)$ \\
\hline No work experience & $0.365^{* *}$ & $(0.146)$ & 0.18 & $(0.130)$ \\
\hline Lowest quartile & -0.110 & $(0.158)$ & $-0.482^{* * *}$ & $(0.128)$ \\
\hline Constant & 0.150 & $(0.101)$ & $0.121^{*}$ & $(0.069)$ \\
\hline Time Dummies & \multicolumn{2}{|c|}{ yes } & \multicolumn{2}{|c|}{ yes } \\
\hline Number of observations & \multicolumn{2}{|c|}{405} & \multicolumn{2}{|c|}{921} \\
\hline Number of individuals & \multicolumn{2}{|c|}{166} & \multicolumn{2}{|c|}{362} \\
\hline Overall Wald test & \multicolumn{2}{|c|}{$\chi_{(14)}^{2}=37.33$} & \multicolumn{2}{|c|}{$\chi_{(14)}^{2}=72.25$} \\
\hline R-squared & \multicolumn{2}{|c|}{0.0548} & \multicolumn{2}{|c|}{0.0300} \\
\hline
\end{tabular}

${ }^{*} p<0.10,{ }^{* *} p<0.05,{ }^{* * *} p<0.01$.

[G2]: Dropout group with only classroom training and no internship placement (183 individuals).

[G3]: Dropout group with classroom training and internship placement (231 individuals).

[G4]: Treatment group with the full treatment (578 individuals).

The time dimension of the panel consists of four time periods: Nov-99, May-01, Nov-01, and May-02. This represents baseline before Projoven, 6 months after Projoven, 12 months after Projoven, and 18 months after Projoven, respectively. In all the models, the base periods are Nov99 and May-01. Two base periods are chosen, as the treatment variable takes the value zero for all individuals (treatment and controls) before the programme (Nov-99).

Robust standard errors adjusted for ECAPs clusters. 
Table A24.

RE estimates [with sample selection correction] Projoven sixth Public Call internship completion effects. Heterogeneous treatment over time [only trainees placed in internships sample] [G4] vs. [G3].

\begin{tabular}{|c|c|c|c|c|c|c|}
\hline & \multicolumn{2}{|c|}{$\begin{array}{l}\text { Dep. var. ov. } \\
\text { employment }\end{array}$} & \multicolumn{2}{|c|}{$\begin{array}{c}\text { Dep. var. formal } \\
\text { employment }\end{array}$} & \multicolumn{2}{|c|}{$\begin{array}{c}\text { Dep. var. monthly } \\
\text { wages }\end{array}$} \\
\hline & Coef. & Std. err. & Coef. & Std. err. & Coef. & Std. err. \\
\hline Internship Completion*Female & -0.051 & $(0.041)$ & $-0.092^{*}$ & $(0.052)$ & -0.140 & $(0.094)$ \\
\hline Internship Completion*No work experience & $0.282^{* * *}$ & $(0.050)$ & 0.085 & $(0.074)$ & $0.370^{* * *}$ & $(0.119)$ \\
\hline Internship Completion*Lowest quartile & 0.017 & $(0.055)$ & 0.009 & $(0.076)$ & $0.422^{* * *}$ & $(0.119)$ \\
\hline Internship Completion*Female*[12 months $]$ & 0.01 & $(0.042)$ & 0.025 & $(0.053)$ & -0.042 & $(0.068)$ \\
\hline Internship Completion*No work experience*[12 months] & -0.034 & $(0.048)$ & -0.103 & $(0.063)$ & -0.015 & $(0.084)$ \\
\hline Internship Completion*Lowest quartile*[12 months] & 0.031 & $(0.052)$ & 0.046 & $(0.063)$ & 0.098 & $(0.090)$ \\
\hline Internship Completion*Female*[18 months] & 0.056 & $(0.046)$ & -0.033 & $(0.053)$ & $0.137^{* *}$ & $(0.068)$ \\
\hline Internship Completion* No work experience*[18 months] & $0.118^{* *}$ & $(0.050)$ & -0.078 & $(0.061)$ & 0.023 & $(0.081)$ \\
\hline Internship Completion*Lowest quartile*[18 months] & 0.03 & $(0.053)$ & 0.002 & $(0.066)$ & -0.025 & $(0.089)$ \\
\hline Female & $-0.061^{* *}$ & $(0.030)$ & $0.103^{* *}$ & $(0.043)$ & $-0.181^{* *}$ & $(0.086)$ \\
\hline No work experience & $-0.443^{* * *}$ & $(0.032)$ & -0.055 & $(0.057)$ & -0.167 & $(0.102)$ \\
\hline Lowest quartile & -0.047 & $(0.037)$ & 0.071 & $(0.054)$ & $-0.489^{* * *}$ & $(0.104)$ \\
\hline Constant & $0.175^{* * *}$ & $(0.020)$ & -0.037 & $(0.026)$ & $0.162^{* * *}$ & $(0.044)$ \\
\hline Time Dummies & \multicolumn{2}{|c|}{ yes } & \multicolumn{2}{|c|}{ yes } & \multicolumn{2}{|c|}{ Yes } \\
\hline Number of observations & \multicolumn{2}{|c|}{2827} & \multicolumn{2}{|c|}{1908} & \multicolumn{2}{|c|}{1772} \\
\hline Number of individuals & \multicolumn{2}{|c|}{708} & \multicolumn{2}{|c|}{679} & \multicolumn{2}{|c|}{646} \\
\hline Overall Wald test & \multicolumn{2}{|c|}{$\chi_{(14)}^{2}=263.49$} & \multicolumn{2}{|c|}{$\chi_{(14)}^{2}=20.38$} & \multicolumn{2}{|c|}{$\chi_{(14)}^{2}=77.01$} \\
\hline R-squared & \multicolumn{2}{|c|}{0.1862} & \multicolumn{2}{|c|}{0.0219} & \multicolumn{2}{|c|}{0.041} \\
\hline
\end{tabular}

${ }^{*} p<0.10, * * p<0.05, * * * p<0.01$.

[G3]: Dropout group with classroom training and internship placement (231 individuals).

[G4]: Treatment group with the full treatment (578 individuals).

The time dimension of the panel consists of four time periods: Nov-99, May-01, Nov-01, and May-02. This represents baseline before Projoven, 6 months after Projoven, 12 months after Projoven, and 18 months after Projoven, respectively. In all the models, the base periods are Nov99 and May-01. Two base periods are chosen, as the treatment variable takes the value zero for all individuals (treatment and controls) before the programme (Nov-99). 
Table A25.

Linear probability model - pooled two-stage least squares estimates [without Mundlak terms]. Projoven sixth Public Call effects on overall employment by level of completion. Heterogeneous treatment over time and endogenous treatment.

\begin{tabular}{ccc}
$\begin{array}{c}\text { Effects } \\
\text { after 6 } \\
\text { months } \\
{\left[\hat{\beta}_{1}\right]}\end{array}$ & $\begin{array}{c}\text { Additional } \\
\text { effects after } \\
\mathbf{1 2} \text { months }\end{array}$ & $\begin{array}{c}\text { Additional } \\
\text { effects after } \\
18 \text { months }\end{array}$ \\
{$\left[\hat{\beta}_{2}\right]$} & {$\left[\hat{\beta}_{3}\right]$} \\
\hline
\end{tabular}

A. Effects of Projoven internship placement

$\begin{array}{lccc}\text { [G3] vs. [G2] } & 0.121 & 0.213 & 0.078 \\ & (0.424) & (0.437) & (0.418) \\ \text { [G4] vs. [G2] } & 0.290 & -0.148 & -0.170 \\ & (0.184) & (0.201) & (0.194)\end{array}$

B. Effects of Projoven internship completion

[G4] vs. [G3] $0.280^{* *} \quad-0.161 \quad-0.023$

\begin{tabular}{rrr}
$(0.137)$ & $(0.150)$ & $(0.138)$ \\
\hline
\end{tabular}

[G2]: Dropout group with only classroom training and no internship placement (183 individuals).

[G3]: Dropout group with classroom training and internship placement (231 individuals).

[G4]: Treatment group with the full treatment (578 individuals).

Clustered robust standard errors are in parentheses.

Table A26.

Linear probability model - pooled two-stage least squares estimates [using initial values of the time-varying regressors as Mundlak terms]. Projoven sixth Public Call effects on overall employment by level of completion. Heterogeneous treatment over time and endogenous treatment.

\begin{tabular}{ccc}
$\begin{array}{c}\text { Effects } \\
\text { after } 6 \\
\text { months }\end{array}$ & $\begin{array}{c}\text { Additional } \\
\text { effects after } \\
12 \text { months }\end{array}$ & $\begin{array}{c}\text { Additional } \\
\text { effects after 18 } \\
\text { months }\end{array}$ \\
{$\left[\hat{\beta}_{1}\right]$} & {$\left[\hat{\beta}_{2}\right]$} & {$\left[\hat{\beta}_{3}\right]$} \\
\hline
\end{tabular}

A. Effects of Projoven internship placement

$\begin{array}{lccc}\text { [G3] vs. [G2] } & 0.142 & 0.194 & 0.062 \\ & (0.396) & (0.423) & (0.405) \\ \text { [G4] vs. [G2] } & 0.266 & -0.133 & -0.153 \\ & (0.186) & (0.202) & (0.195)\end{array}$

B. Effects of Projoven internship completion

[G4] vs. [G3] $\quad 0.272^{* *} \quad-0.157 \quad-0.006$

${ }^{*} p<0.10,{ }^{* *} p<0.05,{ }^{* * *} p<0.01$.

[G2]: Dropout group with only classroom training and no internship placement (183 individuals).

[G3]: Dropout group with classroom training and internship placement (231 individuals).

[G4]: Treatment group with the full treatment (578 individuals).

Clustered robust standard errors are in parentheses. 
Table A27.

Linear probability model - pooled two-stage least squares estimates with sample selection correction (Semykina and Wooldridge, 2006) [without Mundlak terms]. Projoven sixth Public Call effects on formal employment by level of completion. Heterogeneous treatment over time and endogenous treatment.

\begin{tabular}{ccc}
$\begin{array}{c}\text { Effects after } \\
6 \text { months } \\
{\left[\hat{\beta}_{1}\right]}\end{array}$ & $\begin{array}{c}\text { Additional } \\
\text { effects after 12 } \\
\text { months }\end{array}$ & $\begin{array}{c}\text { Additional } \\
\text { effects after } \\
18 \text { months }\end{array}$ \\
{$\left[\hat{\beta}_{2}\right]$} & {$\left[\hat{\beta}_{3}\right]$} \\
\hline
\end{tabular}

A. Effects of Projoven internship placement

$\begin{array}{lccc}\text { [G3] vs. [G2] } & 0.487 & -0.057 & -0.115 \\ & (0.493) & (0.537) & (0.491) \\ \text { [G4] vs. [G2] } & 0.591 & 0.087 & -0.076 \\ & (0.689) & (0.726) & (0.682)\end{array}$

B. Effects of Projoven internship completion

[G4] vs. [G3] $0.476^{* * *} \quad-0.031 \quad-0.324$

* $p<0.10,{ }^{* *} p<0.05$, *** $p<0.01$.

[G1]: Control group (992 individuals).

[G2]: Dropout group with only classroom training and no internship placement (183 individuals).

[G3]: Dropout group with classroom training and internship placement (231 individuals).

[G4]: Treatment group with the full treatment (578 individuals).

Clustered robust standard errors are in parentheses.

Table A28.

Linear probability model - Two-stage least squares estimates with sample selection correction (Semykina and Wooldridge, 2006) [using initial values of the time-varying regressors as Mundlak terms]. Projoven sixth Public Call effects on formal employment by level of completion. Heterogeneous treatment over time and endogenous treatment.

\begin{tabular}{ccc}
$\begin{array}{c}\text { Effects } \\
\text { after } 6 \\
\text { months }\end{array}$ & $\begin{array}{c}\text { Additional } \\
\text { effects after } \\
\mathbf{1 2} \text { months }\end{array}$ & $\begin{array}{c}\text { Additional } \\
\text { effects after 18 } \\
\text { months }\end{array}$ \\
{$\left[\hat{\beta}_{1}\right]$} & {$\left[\hat{\beta}_{2}\right]$} & {$\left[\hat{\beta}_{3}\right]$} \\
\hline
\end{tabular}

A. Effects of Projoven internship placement

$\begin{array}{lccc}\text { [G3] vs. [G2] } & 0.646 & -0.086 & -0.260 \\ & (0.512) & (0.554) & (0.509) \\ \text { [G4] vs. [G2] } & 0.590 & 0.094 & -0.086 \\ & (0.677) & (0.698) & (0.665)\end{array}$

B. Effects of Projoven internship completion

[G4] vs. [G3] $0.424^{* *} \quad 0.016 \quad-0.283$

$\frac{(0.174)}{*} p<0.10, * * p<0.05, * * * p<0.01$.

[G1]: Control group (992 individuals).

[G2]: Dropout group with only classroom training and no internship placement (183 individuals).

[G3]: Dropout group with classroom training and internship placement (231 individuals).

[G4]: Treatment group with the full treatment (578 individuals).

Clustered robust standard errors are in parentheses. 
Table A29.

Two-stage least squares estimates with sample selection correction (Semykina and Wooldridge, 2006) [without Mundlak terms]. Projoven sixth Public Call effects on monthly wages by level of completion. Heterogeneous treatment over time and endogenous treatment.

\begin{tabular}{ccc}
$\begin{array}{c}\text { Effects } \\
\text { after 6 } \\
\text { months }\end{array}$ & $\begin{array}{c}\text { Additional } \\
\text { effects after } \\
12 \text { months }\end{array}$ & $\begin{array}{c}\text { Additional } \\
\text { effects after 18 } \\
\text { months }\end{array}$ \\
{$\left[\hat{\beta}_{1}\right]$} & {$\left[\hat{\beta}_{2}\right]$} & {$\left[\hat{\beta}_{3}\right]$} \\
\hline
\end{tabular}

A. Effects of Projoven internship placement

$\begin{array}{lccc}\text { [G3] vs. [G2] } & 0.003 & 0.417 & -0.198 \\ & (0.769) & (0.792) & (0.754) \\ \text { [G4] vs. [G2] } & 0.407 & 0.484 & -0.340 \\ & (1.038) & (1.095) & (1.032)\end{array}$

B. Effects of Projoven internship completion

[G4] vs. [G3] $1.229^{*} \quad-0.895^{*} \quad-0.769$

$\frac{(0.633)}{* p<0.10,{ }^{* *} p<0.05,{ }^{* * *} p<0.01 .}$

[G1]: Control group (992 individuals).

[G2]: Dropout group with only classroom training and no internship placement (183 individuals).

[G3]: Dropout group with classroom training and internship placement (231 individuals).

[G4]: Treatment group with the full treatment (578 individuals).

Clustered robust standard errors are in parentheses.

Table A30.

Two-stage least squares estimates with sample selection correction (Semykina and Wooldridge, 2006) [using initial values of the time-varying regressors as Mundlak terms]. Projoven sixth Public Call effects on monthly wages by level of completion. Heterogeneous treatment over time and endogenous treatment.

\begin{tabular}{ccc}
$\begin{array}{c}\text { Effects } \\
\text { after 6 } \\
\text { months }\end{array}$ & $\begin{array}{c}\text { Additional } \\
\text { effects after } \\
\mathbf{1 2} \text { months }\end{array}$ & $\begin{array}{c}\text { Additional } \\
\text { effects after } \\
\mathbf{1 8} \text { months }\end{array}$ \\
{$\left[\hat{\beta}_{1}\right]$} & {$\left[\hat{\beta}_{2}\right]$} & {$\left[\hat{\beta}_{3}\right]$} \\
\hline
\end{tabular}

A. Effects of Projoven internship placement

$\begin{array}{lccc}\text { [G3] vs. [G2] } & 0.003 & 0.417 & -0.198 \\ & (0.769) & (0.792) & (0.754) \\ \text { [G4] vs. [G2] } & 0.407 & 0.484 & -0.340 \\ & (1.038) & (1.095) & (1.032)\end{array}$

B. Effects of Projoven internship completion

[G4] vs. [G3] $1.229^{*} \quad-0.895^{*} \quad-0.769$

* $p<0.10, * * p<0.05, * * * p<0.01$.

[G1]: Control group (992 individuals).

[G2]: Dropout group with only classroom training and no internship placement (183 individuals).

[G3]: Dropout group with classroom training and internship placement (231 individuals).

[G4]: Treatment group with the full treatment (578 individuals).

Clustered robust standard errors are in parentheses. 
Figure A1.

Kernel densities propensity score (predicted probability of participating in the training). Control group and participants in Projoven sixth Public Call.
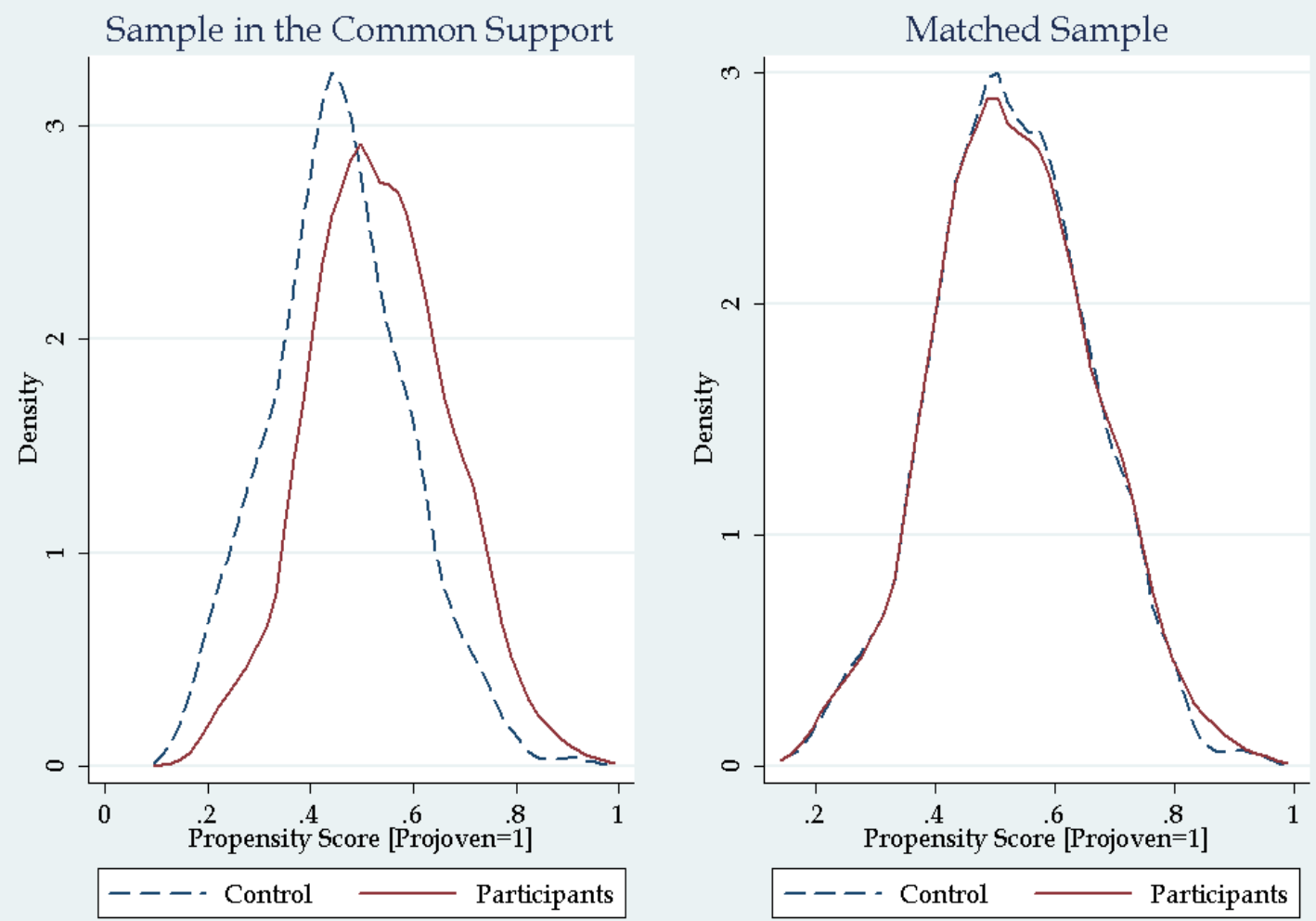